NBER WORKING PAPER SERIES

\title{
DEFLATION AND MONETARY POLICY IN A HISTORICAL PERSPECTIVE: REMEMBERING THE PAST OR BEING CONDEMNED TO REPEAT IT?
}

\author{
Michael D. Bordo \\ Andrew Filardo \\ Working Paper 10833 \\ http://www.nber.org/papers/w10833
NATIONAL BUREAU OF ECONOMIC RESEARCH
1050 Massachusetts Avenue
Cambridge, MA 02138
October 2004

This paper was prepared for the 40th Panel Meeting of Economic Policy in Amsterdam (October 2004). The authors would like to thank Jeff Amato, Palle Andersen, Claudio Borio, Gauti Eggertsson, Gabriele Galati, Craig Hakkio, David Lebow and Goetz von Peter, Patrick Minford, Fernando Restoy, Lars Svensson, participants at the 3rd Annual BIS Conference as well as seminar participants at the Bank of Canada and the International Monetary Fund for helpful discussions and comments. We also thank Les Skoczylas and Arturo Macias Fernandez for expert assistance. The views expressed are those of the authors and not necessarily those of the Bank for International Settlements or the National Bureau of Economic Research. The views expressed herein are those of the author(s) and not necessarily those of the National Bureau of Economic Research.

(O2004 by Michael D. Bordo and Andrew Filardo. All rights reserved. Short sections of text, not to exceed two paragraphs, may be quoted without explicit permission provided that full credit, including $\odot$ notice, is given to the source. 
Deflation and Monetary Policy in a Historical Perspective: Remembering the Past or Being Condemned to Repeat It?

Michael D. Bordo and Andrew Filardo

NBER Working Paper No. 10833

October 2004

JEL No. E31, N10

\begin{abstract}
$\underline{\text { ABSTRACT }}$
What does the historical record tell us about how to conduct monetary policy in a deflationary environment? We present a broad cross-country historical study of deflation over the past two centuries in order to shed light on current policy challenges. We first review the theoretical literature on deflation. We then characterize deflation by distinguishing among the "good, the bad and the ugly" ones - considering both empirical determinants and historical narratives of each type. Emphasis is put on the linkages between the current inflation environment and that of the gold standard period. Particular attention is also put on what the historical record reveals about policies to escape undesirable deflation. In this regard we develop a policy typology based on the relative merits of interest rate and monetary instruments in combating different types of inflation/deflation behavior.
\end{abstract}

\author{
Michael D. Bordo \\ Department of Economics \\ New Jersey Hall \\ Rutgers University \\ New Brunswick, NJ 08901-1284 \\ and NBER \\ bordo@econ.rutgers.edu \\ Andrew Filardo \\ Monetary and Economic Department \\ Bank for International Settlements \\ Centralbahnplatz 2 \\ CH-4002 Basel \\ Switzerland \\ andrew.filardo@bis.org
}




\section{TABLE OF CONTENTS}

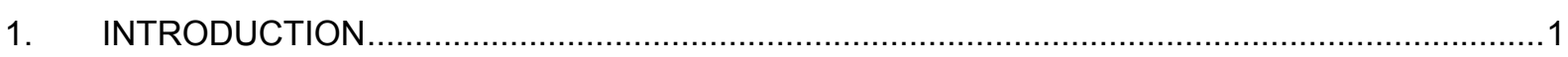

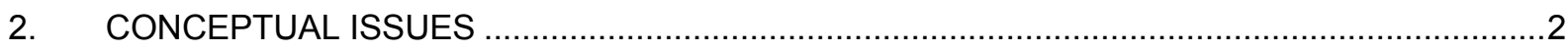

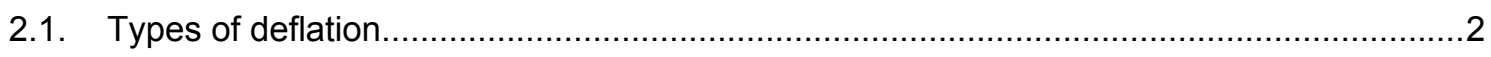

2.2. The optimal inflation/deflation rate from a theoretical perspective ................................... 3

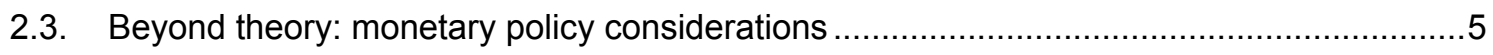

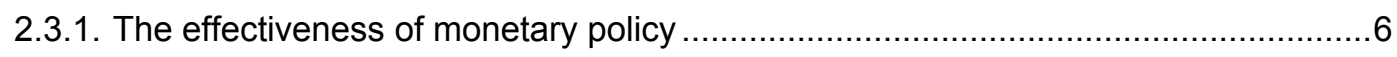

2.3.2. Deflation, monetary regimes and credible nominal anchors .................................6

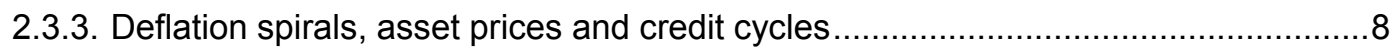

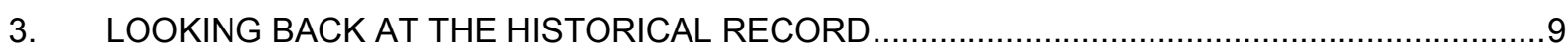

3.1. Historical narrative: evidence from the nineteenth century............................................ 10

3.1.1. 1873-1896: a good deflation that turned somewhat bad ....................................10

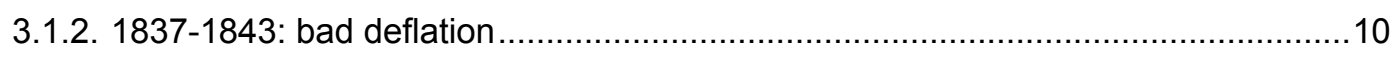

3.2. Historical narrative: evidence from the twentieth century .............................................11

3.2.1. 1919-1921: bad, possibly ugly for some, deflation .............................................11

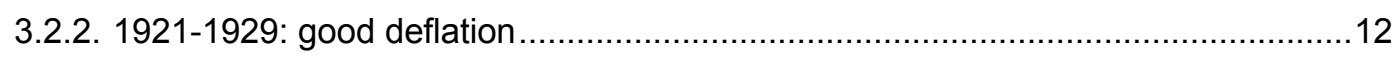

3.2.3. 1929-1933 (the Great Contraction): an ugly deflation ..........................................12

3.2.4. 1937-38 and 1948-1949: 2 episodes of bad deflation and the zero nominal bound13

3.2.5. Modest deflation in the mid-twentieth century ................................................... 14

3.2.6. Summary: the historical setting in which deflations occur.....................................14

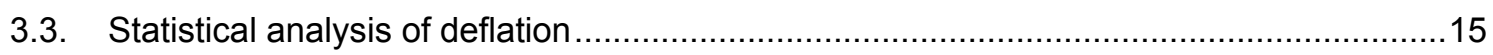

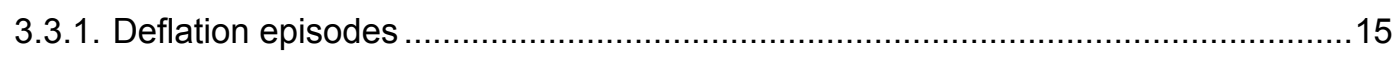

3.3.2. Asymmetric persistence of deflation and inflation .............................................. 15

3.3.3. Further investigations into asymmetry........................................................ 17

3.3.4. Statistical determinants of the good, the bad and the ugly deflations.....................18

3.3.5. Deflation and the zero lower bound for nominal interest rates.............................20

4. INFLATION, DEFLATION AND MONETARY POLICY: THE ZONAL APPROACH ..................21

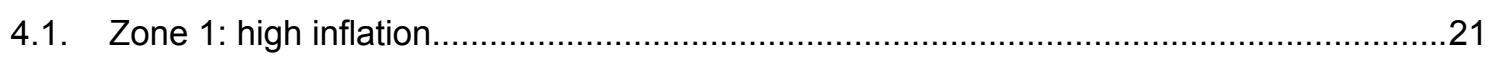

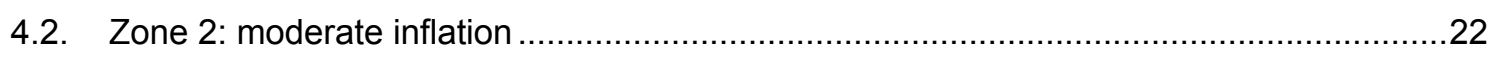

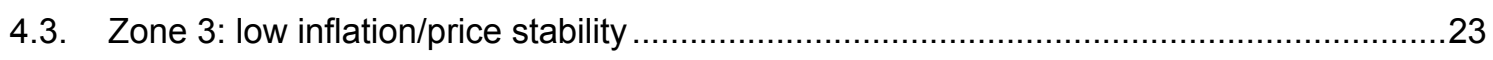

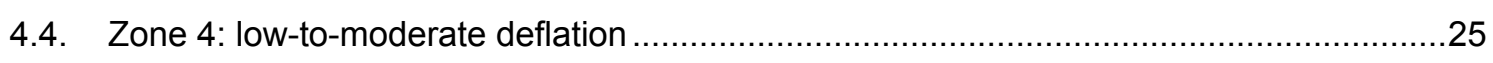

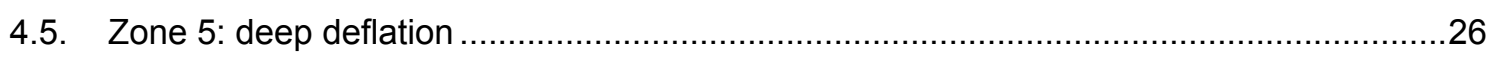

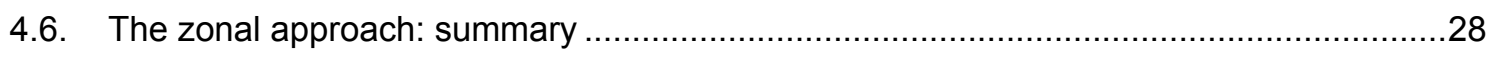

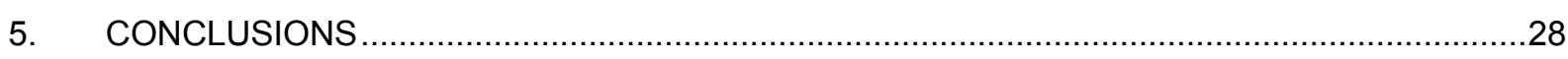

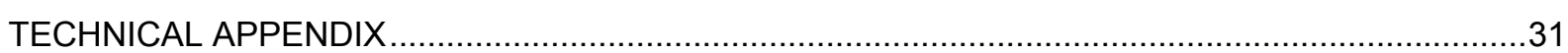

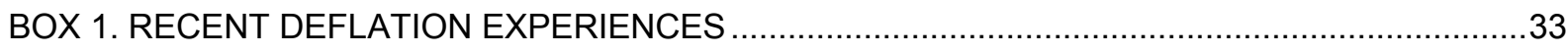

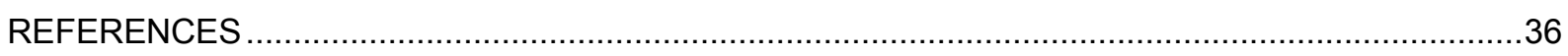

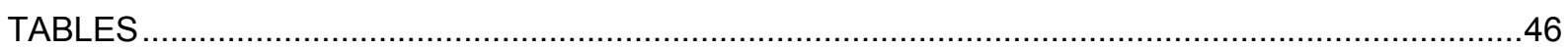

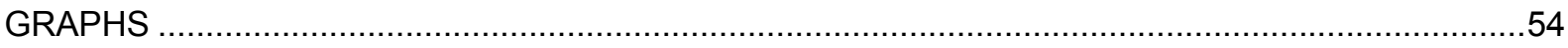




\section{INTRODUCTION}

After 20 years during which inflation was viewed as public enemy number one, the spotlight has recently shifted to deflation, defined as a sustained decline in the aggregate price level. Although deflation has been treated as a new and daunting policy challenge, it is far from new and need not be daunting. In the century before World War I, price levels in many countries declined as often as they rose and, moreover, falling prices were not always associated with recessions. Indeed many deflation episodes were "good" in the sense that they were associated with productivity-driven economic growth.

Our paper looks back in history to the time when deflation was commonplace in order to draws lessons for the current policy environment (see Table 1 which presents evidence on the incidence of deflation for 30 countries over 2 centuries). Deflation and near-deflation experiences in recent years around the world (briefly reviewed in Box 1) have raised important monetary policy questions, such as how bad is deflation? how can an unwelcome deflation be avoided? how can one escape a deflation? what type of institutional frameworks are more immune from the negative aspects of deflation? To be sure, there are differences between the policy environment today and the ones in the distant past. But, the similarities are sufficiently close to shed light on current policy challenges. In other words, the historical record provides a fertile "laboratory" to study how an economic environment behaves in deflationary times and to gain some insight into the policies that may help current policy makers.

The paper begins with a brief survey of some theoretical issues and monetary policy dimensions of deflation. This discussion provides a backdrop with which to interpret much of the evidence on deflation that we present, which draws from the historical records of many countries with several having data going back as far as the past two centuries. Our survey of history corroborates the view that historical deflations fall into three broad categories: "the good, the bad and the ugly". To understand the differences, we first use historical narratives to identify and illustrate each of these three types of deflation. We then provide a more formal statistical evaluation of the determinants of different types of deflationary episodes. Armed with these results, we turn in the last section to lessons to be learned about the efficacy of monetary policy in dealing with inflation/deflation, and offer a holistic approach to frame the challenges facing policy makers. In this regard, several different zones of price level movements, ranging from high inflation to deep deflation, highlight the differential role of monetary policy in each. From this perspective, the contemporary policy tradeoffs of dealing with deflation are, arguably, put in a clearer light. In particular, the historical record suggests that all deflations are not alike and therefore may require different approaches.

Our historical approach leads us to conclude that most central banks today put too little emphasis on the role of monetary aggregates in assessing the broad strategic policy tradeoffs presented by deflation and that economists are often too eager to characterize low inflation economies as being in a liquidity trap. History shows that the usefulness of monetary aggregate targeting (versus interest rate targeting) depends nonlinearly on the inflation/deflation zone the economy is in. For high inflation and deep deflation, monetary targeting appears to be a relatively effective guide for policy. When inflation is low, the usefulness of the monetary aggregates may be exceeded by short-term interest rates, especially if velocity is sufficiently unpredictable. In the broader context of monetary frameworks, however, our analysis sheds light on the importance of mixed monetary policy strategies. History suggests that a monetary framework that combines the best features of 
monetary aggregate and interest rate targeting, not unlike the current approach of the European Central Bank, is more likely to be a robust approach to the varied inflation/deflation challenges, as have been experienced in the past.

\section{CONCEPTUAL ISSUES}

Deflation can be a confusing concept for policymakers. At the most simple level, deflation is a statistical definition - a falling price level. But in policy discussions, deflation can represent both the symptom and the cause of different economic phenomena. In this section, we discuss various features of deflation to set up our historical analysis of the different types of deflations.

\subsection{Types of deflation}

History suggests that deflations come in three basic types: the good, the bad and the ugly (Bordo, Landon-Lane and Redish (2004) and Borio and Filardo (2004)). The differences among these types arise from the shocks that cause them and the impact of falling prices on how the economy subsequently responses.

Bad deflations are those associated with recessions. In the pre-1960 period, economic contractions arising from demand deficiencies, ie the leftward shift in aggregate demand, were more likely associated with deflation. In the 1960 to mid-1990s period when the trend rate of inflation was positive, economic weakness was associated with disinflation. An empirical question still remains about whether deflation, in contrast to disinflation, made economic downturns worse than would otherwise be the case. If deflation was not simply a symptom of weak demand in a low inflation environment but rather the cause of additional rounds of economic weakness, bad deflations would be outcomes that policy makers might want to fight more vigorously. We will provide a more nuanced understanding of this issue of bad deflations in the following theoretical discussion of optimal inflation/deflation rates and in the empirical section by offering new evidence on the symmetry of the inflation/deflation processes in the historical data.

By means of contrast, good deflations are those that arise from positive supply shocks. In a standard aggregate supply and demand framework, an outward shift in the supply curve will put downward price pressures. If the initial inflation rate is low enough, deflation may be realized. Such shocks would be generally accompanied by lower product prices, but higher profits, rising real wages, higher asset prices and stronger financial sector performance.

Ugly deflations represent periods of steeply declining prices associated with severe recession. During these periods, declining prices arising from aggregate demand are sufficient to feedback to aggregate supply via onerous debt burdens, personal and corporate bankruptcies, financial crises and other adverse conditions; policy failures, especially from monetary policy, may add to the severity and the length of the downturns. As we will show, such conditions have occurred, but have been quite rare. The recent literature on deflation and monetary policy has focused on the possibility that monetary policy may lose its effectiveness in such extreme situations as when a liquidity trap occurs; while the theoretical literature offers novel solutions for such situations, we find little evidence that such extreme situations are of practical policy relevance today.

To be sure, the taxonomy of the good, the bad and the ugly is simplistic. But this rhetorical device gets at the heart of the policy issue. Not all deflations are alike. As the labels suggest, 
good deflations are likely to be less worrisome to a policy maker than a bad or ugly deflation. Therefore it is important to distinguish types of deflation.

Moreover, it is important to note that while deflation has the possibility of making an undesirable condition worse, it is also true that inflation can do the same. While we will not be stressing the inflation record, it is well known that inflation can cause economic distortions that rise with the level of inflation. Inflation can lead to direct resource costs as agents expend time and effort to economize on cash balances. Moreover, high inflation has traditionally been associated with information-jamming volatility in relative prices which not only distorts final good allocations but can also "throw sand in the gears" of the labor and capital markets. In emerging market economies, high inflation environments has led in the past to the closure of domestic long-term bond markets and to an increase in economic uncertainty, reduced investment and lower growth. Even though this paper will focus on what we can learn about the policy tradeoffs in a deflationary environment, we use the inflation history as a means of comparison when framing the policy options.

\subsection{The optimal inflation/deflation rate from a theoretical perspective}

In theory, "deflation is everywhere and always a monetary phenomenon", to paraphrase Milton Friedman (1968). It is monetary in the sense that the sustained growth in some monetary aggregate relative to the trend growth of real output (adjusted for the trend in velocity) determines the rate of change in the price level.

Theory also provides insights on the costs and possible benefits of deflation. On the one hand, Friedman (1969) argued that deflation might be optimal. In an economy with fully flexible wages and prices, the costs of inflation arise from the opportunity cost of holding money balances. Friedman advocates a negative optimal inflation rate, ie deflation, equal in absolute value to the long run growth of the real economy or, in general, equal to the real interest rate. ${ }^{1}$ In other words, when the nominal interest rate is zero, the return on money and risk-free bonds would be equilibrated, thereby leading to an optimal outcome. ${ }^{2}$ Extending this model to the world of public finance leads to a refinement of this finding. Under particular circumstances, it would be optimal to tax money balances at the Ramsey tax rate. This could suggest a nominal interest rate above zero. But other versions of this model, eg one where money is viewed as an intermediate good, would endorse the original Friedman rule because of the general principle in public finance that only final goods should be taxed (Chari et al (1991), Schmitt-Grohé and Uribe (2001)). ${ }^{3}$

On the other hand, theories of inflation in economies subject to nominal rigidities lead to higher optimal inflation/deflation rates. In an economy subject to nontrivial price stickiness, for example, the optimal inflation rate would generally be zero, ignoring the costs arising

1 The same outcome can be achieved by paying interest on money balances equal to the yield on close money substitutes.

2 Lucas (2000) estimates, while admittedly with a wide potential range, that the decline in the steady-state inflation rate from zero to a deflation of roughly 3 percent could yield the same economic benefits as a decline of inflation from 11 percent to zero percent.

3 Feldstein (1999) also argues that the interaction of the tax code and inflation causes significant welfare losses at low levels of positive price increases (ie inflation). More efficient capital taxation would improve intergenerational welfare. 
from holding money balances. ${ }^{4}$ If both sticky prices and costly money holding motives were operative, the optimal deflation rate would be somewhere between 0 and the real interest rate (Chari (2004)). Of note, this range is below conventional implicit and explicit inflation targets used by central banks today.

Other forms of nominal rigidities have been emphasized in theoretical studies to justify an optimal positive inflation rate. Akerlof, Dickens and Perry (1996) have argued that downward nominal wage inflexibility (ie the reluctance of employees to accept cuts in nominal wages) could be a significant source of economic costs that would be avoided by keeping the inflation rate sufficiently high. But while this view is logically consistent from a theoretical point of view, the empirical support at the macroeconomic level has been weak. Lebow et al (1999), for example, raised doubts about the macroeconomic significance of this view. They argue that the type of downward nominal rigidity would imply highly asymmetric Phillips curves, which does not appear to be consistent with the data in the post-World War II period.

This theory rests heavily on the assumption that employees dislike nominal wage cuts more than real wage cuts of the same size - a form of price illusion. Recent wage setting behavior, especially in Asian economies experiencing persistent deflation, has raised doubts about the significance of this type of price illusion. In Asia, downward nominal wage flexibility became increasingly evident as the deflation environment became more familiar. ${ }^{5}$ This all goes to suggest that such notions of downward wage inflexibility that were formed during the Great Inflation era may in fact be regime dependent. It is possible that once a low inflation or moderate deflation environment were to become more familiar, the past psychological aversion to downward nominal, rather than real, movements would become less of a constraint. ${ }^{6}$ Unfortunately, from a historical perspective, testing such theories would require

4 Selgin (1997) argues that fixed nominal wage contracts are a much more important source of economic distortions than final goods prices. If so, in a world of productivity growth, stable nominal wages contribute to macroeconomic efficiency, leading to his view of a "productivity norm", ie a deflation rate set to the rate of productivity growth. Precursors of this view go back to Keynes and his contemporaries.

5 Kuroda and Yamamoto (2003) find statistical evidence of nominal wage rigidities in Japan, but one is struck by their figure 1 which shows that nominal wage cuts are far from rare. Likewise, evidence from Switzerland (Fehr and Goette (2004)) and the United States (Lebow et al (1999)) is consistent with the fact that nominal wage cuts are not rare; Fehr and Goette (2004) also show the distribution of nominal wage changes does shift over time, especially as the economy shifts from experiencing inflation to deflation. Fan (2003) documents time series evidence of nominal wage cuts in Hong Kong. Overall, the evidence on nominal wage flexibility is inconclusive. On the one hand, there is ample evidence that nominal wage changes tend to pile up at zero in cross sectional data, especially in economies that are used to inflation. On the other hand, there is ample evidence of nominal wage cuts, which weakens the argument that employees simply will not accept nominal wage cuts. Moreover, some evidence suggests that total nominal compensation is more flexible than nominal wages (Lebow et al (1999)). On the whole, in low inflation and deflation environments, the empirical record is consistent with the view that workers can reframe their wage expectations, putting more emphasis on real rather than nominal wage changes.

6 Bewley (1995) stresses the possible adverse morale effects of nominal wage cuts. Again, however, the notion of what effects morale would depend on the inflation regime. Akerlof et al (2000) raise the possibility that near-rational agents may systematically underestimate the costs of low inflation and hence produce an equilibrium with a lower unemployment rate and more moderate wage demands than would be the case in a purely rational expectations model. In either case, the theories are interesting but not sufficiently explicit to understand how behavior might change as agents became accustomed to a low inflation environment. Some of these eclectic theories reflect the fact that the literature on price and wage stickiness is based on a somewhat not well understood view of firm behavior. For example, Blinder et al (1998) finds considerable explanatory gaps between academic theories of price stickiness and real world survey evidence, yet concludes there is cross-sectional evidence that supports the notion of downward nominal wage rigidities at the microeconomic level. 
cross-sectional data that is not readily available. Instead, we will use indirect measures to address the empirical issue.

Another cost of deflation is related to redistributive losses. ${ }^{7}$ Friedman's optimum quantity of money assumes that deflation is fully anticipated. If this is not the case, then agents who fail to fully anticipate deflation and are unable to index their contracts would suffer losses relative to those who could. History shows that such redistributive costs can be rather significant, as the losers (for example, debtors, farmers, workers, etc) had at times reacted to their situation through political agitation. Moreover, debt deflation - a fall in the price level that raises the real value of nominal debt - can exacerbate the costs of a deflation (Fisher (1933)). This redistributive cost, however, would not obviously be any different than that of a similarlysized disinflation in an environment of positive inflation.

Financial stability could also be affected by unanticipated price movements. In an economic environment without complete financial markets in nominal risk sharing, unanticipated price shocks could have important consequences for financial instability and the associated macroeconomic costs (Schwartz (1995)). Bordo, Dueker and Wheelock (2002, 2003) document that, in the pre-1934 period, aggregate price shocks had a significantly negative impact on financial conditions. By the 1970s, however, inflation shocks rather than price shocks were playing the dominant role in this respect.

In sum, theory provides some guidance on the optimal inflation rate, but such guidance is somewhat wide ranging. The precise estimate would depend on critical, yet controversial, assumptions. In other words, reasonable, or at least not implausible, assumptions could justify a range of estimates. In general, the optimal inflation rate should be low, possibly as low as a moderate deflation. ${ }^{8}$ From the tenor of the current policy debate, however, one would be led to believe that most policy makers consider deflation to be a subpar outcome. In a narrow sense this might be tautologically true. For explicit and implicit inflation targeters, a deflation outcome indicates a policy failure because, to our knowledge, no central bank targets deflation. But, in a broader sense, the debate about how low the inflation rate should be is still open, with modest steady-state deflation deserving ample consideration.

\subsection{Beyond theory: monetary policy considerations}

In policy circles, some of the theoretical conclusions might still sound impractical, imprudent and, in the extreme, wrong-headed. In this section we review various important dimensions of deflation dynamics that may lead policy makers to take a more averse view of deflation. We emphasize the potential effects of deflation on the effectiveness of monetary policy, the role

7 See Humphrey (2003) for a discussion of how classical economists looked at the problem of systematic redistributions during unanticipated deflations. The deflation-induced redistributions were generally seen as having net negative knock-on effects because the consequences for the most leveraged in society were often disproportionately large.

8 In determining a quantitative measure of this rate, policymakers would also have to factor in statistical biases in conventionally-measured inflation rates. The well-known biases in index theory suggest that measured price changes are biased upwards. In theory, the costs of inflation and deflation should be evaluated relative to the economically meaningful, rather than the purely statistical measure. In the United States, for instance, the bias has been estimated to be somewhere between .5 to 1 percent, which may not be too far out of line with ballpark estimates in other economies. These estimates are consistent with those found in Lebow and Rudd (2003) and Rodriguez-Palenzuela and Wynne (2004). If true, actual deflation would likely coincide with a positive rate of measured inflation somewhere below 1 percent. Of course, inflation illusion may also play a role, but such effects are thought to be small. 
of the monetary policy regime on deflation expectation formation and the potential complications from asset price booms and busts. The historical record can provide some insights into the relevance of the factors as well as the tradeoffs.

\subsubsection{The effectiveness of monetary policy}

Deflation is also thought to complicate the conduct of monetary policy in various ways. First, the recent spectre of deflation represents a relatively unfamiliar territory in which central banks have to operate. To the extent that economic relationships that hold in moderate inflation regimes break down during deflations, a central bank may find it harder to interpret economic developments and to understand the monetary transmission mechanism. This new policy environment could also make it more difficult for the monetary authority to communicate its policy stance and future intentions to the public. This, of course, could have real effects on the ability of the private sector to form expectations and plan optimally. One would expect, however, that these costs would be transitory as central banks and the public became accustomed to the new environment.

Second, the zero lower bound for short-term nominal interest rates would also adversely complicate monetary policy, if only because central banks could not rely on interest rates to pursue their inflation and output goals. Again, such an environment would be a challenge, at least in the short run, as policymakers would have to alter their tactics and recalibrate their policy tools. The interwar period during the 20th century offers a glimpse into some of the possible complications and will be discussed below.

Third, deflationary environments can hinder the ability of central banks to pursue countercyclical monetary policies. In the extreme, if a deflation was deep enough and expectations became sufficiently entrenched, a liquidity trap could form (Bernanke (2002), Eggertsson and Woodford (2003), Fujiki et al (2001), Keynes (1936), Krugman (1998), Svensson $(2001,2003 \mathrm{a} \& b))$. Economists often point to the 1930s as an example of such conditions. Liquidity traps represent an extreme situation where the tools of monetary policy would be ineffective in stimulating aggregate demand. Such a situation would preclude the generally-presumed benefits of countercyclical policies on economic welfare.

All these policy complications are clearly costs that would have to be factored into the decision to pursue a low inflation/deflation policy. Arguably, most of the costs could prove to be transitory as a central bank became accustomed to the new policy environment.

\subsubsection{Deflation, monetary regimes and credible nominal anchors}

One perennial issue in monetary economics is the design of nominal anchors and their role in shaping private sector expectations. In the past several decades, economists and policymakers have emphasized the importance of low, stable inflation. Part of the emphasis reflected the history of the fiat currency regime in the twentieth century. Reining in high inflation was a challenge. Should current fiat money regimes put greater emphasis on price stability? In the nineteenth and early twentieth century, the emphasis was squarely on a credible price level anchor in the form of the gold standard, which offers some insights about how a more effective anchor may influence the economic environment.

The classical gold standard provides a good example of how important the monetary regime is in determining the aggregate price level and shaping expectation about the future level. Under the gold standard, the world price level was determined by the demand and supply for monetary gold and, in turn, by a function of gold production and the relative demands on gold for monetary and non-monetary uses (Bordo (1999)). Moreover, the international monetary 
arrangements at the time meant that the price levels of individual countries would be tied together by commodity market arbitrage and capital flows. Deviations of one country's price level from its trading partners and interest rates from the world financial center in London, provided incentives for both corrective gold flows and short-term capital flows.

The self-correcting nature of the gold standard had powerful effects on price expectations. Shocks to the gold market, such as gold discoveries, naturally caused the price level to move but it would be expected to revert back towards some stable value, ie prices would tend to be mean-reverting. In the long run, prices were anchored by the marginal cost of producing gold. In the short run, periods of generalized global inflation following gold discoveries were expected to be succeeded by periods of deflation because gold discoveries would increase the total world gold stock, and hence the world price level. This, in turn, reduced the real price of gold (given the fixed nominal price set by the monetary authorities) and led to lower gold production and greater substitution of gold from monetary to non-monetary uses. ${ }^{9}$

Consistent with the belief that prices were mean-reverting, the expected inflation rate hovered around zero and long-run price level uncertainty was low (Klein (1975)). This had important implications for the stability of nominal interest rates (Friedman and Schwartz (1963), especially expectations over long horizons. Expectations about short-term interest rates could be more variable. This partly reflected the ability, albeit limited, of monetary authorities to offset demand and supply shocks within the target zone provided by the gold points framework. ${ }^{10}$ In the interwar period and possibly pre-1914, for example, central banks engaged in sterilization policies to offset the impact of international gold movements (Bloomfield (1959), Dutton (1984), Nurkse (1944)). In addition, some of the effects of deflation were offset by the use of key currencies as central bank reserves instead of gold and by the increasing use of bank money and convertible fiduciary money as gold substitutes (Triffin (1960)).

Are the lessons from the gold standard regime still valuable today? Current fiat money regimes provide central banks with much more flexibility than a commodity standard regime but they lack the self-correcting mechanisms inherent in the gold standard. To be sure, the fiat currency regime in the latter half of the twentieth century, especially in the 1970s and early 1980 s, showed little resemblance to the gold standard regime as prices appeared to be unmoored. But, recent history has shown that well-designed fiat money regimes can provide an effective nominal anchor. The holding power of the anchor in the fiat money regime, however, depends on the ability and willingness of the monetary authority to pursue its low

9 It should be noted that in an environment of positive productivity driven real growth there would be a tendency towards secular deflation unless offset by technical innovation in gold production or by gold discoveries (by contrast, if gold was a depletable, durable resource then steady-state deflation would be inevitable (Bordo and Ellson (1985))).

10 During the gold standard period, gold parity was bounded by the gold points (the cost of shipping gold among the various financial centers). Following Svensson (1994), Bordo and MacDonald (2004) show that the gold points served as a target zone in the sense of Krugman (1991) and implied some scope for the core countries in the gold bloc to temporarily offset real and nominal disturbances such as was the case in England, France and Germany. An important feature of the flexibility was that markets believed that the gold parity would be preserved under virtually all circumstances.

11 Smaller countries which lacked financial maturity and credibility had less room for maneuver and hence were less able to shield themselves from the full brunt of deflation. Because they had difficulty maintaining the convertibility of their currencies, but when they opted for floating they often suffered capital flight. Their options were to adopt a currency board arrangement with close to $100 \%$ gold reserves or to decouple themselves from capital flows. 
inflation goal. The success of monetary authorities in the past decade to achieve low, stable inflation rates around the world has shown that such a regime can work.

Looking forward, a key policy question is whether such fiat money regimes can be improved upon. Some economists have advocated that central banks put further emphasis on price stability by adopting "price level" targeting regimes. Proposals for price level targeting generally have come in two distinct flavors. One version emphasizes a fixed price level target. In this case, a monetary authority would target a given price level at a particular policy horizon. If the price level exceeded (or were expected to exceed) the target, the monetary authority would tighten policy; and if it fell below target, the monetary authority would ease policy. As under the gold standard, this policy would generate alternating periods of transitory inflation and deflation. Such an approach would have the advantage of long-run price predictability, which conventional inflation targeting regimes do not (Bordo, Dittmar and Gavin (2003), Riksbank (2003), Svensson (1999b)). But it could have the disadvantage of short-run volatility if downward nominal rigidities were important. In an alternative version of the scheme, a monetary authority would target a rising price level - in a sense, this would be equivalent to average inflation targeting rather than a conventional period-by-period inflation rate target (King (1999)). This approach would still share the favorable feature of long-run price predictability. If a shock were to cause the price level to fall below target, then the central bank would take an accommodative monetary stance to put upward pressure on prices until the price level returned to target. If, however a shock were to cause the price level to exceed the target, the central bank would respond by tightening monetary conditions to return to target. If the central bank were sufficiently patient towards achieving its target, the return of the price level could be achieved without engendering deflation, or at the very least minimizing the need to engender deflation. In either variant of price level targeting, the policy regime would more closely approximate the workings of the gold standard period, and hence enhance the policy relevance of studying the historical record.

\subsubsection{Deflation spirals, asset prices and credit cycles}

An important monetary policy concern arises from the possibility of deflation spirals - selfreinforcing waves of downward price pressures. An oft-mentioned mechanism that could generate a spiral is consumer expectations. If a deflation were expected, consumers might refrain from spending today in the hope of paying lower prices tomorrow. This would lower velocity, which in turn would reduce prices, and so on.

Another, possibly more policy-relevant, mechanism that is thought to be associated with spiraling deflation is asset price boom and bust behavior, an issue that has attracted considerable attention in recent years. ${ }^{12}$ One implication from this literature has been that the risks of deflation might be understated in the conventional focus on supply and demand shocks. In this scenario, a spectre of deflation may cause forward-looking investors to expect a reduction in profits and a general decline of economic activity, especially if the economy is subject to downward nominal rigidities. The collapse in asset prices could have a chilling effect on economic activity which would then add to the deflationary pressures. This process could be reinforced by balance sheet problems of firms and households, who might retrench or even renege on debt obligations in bankruptcy (Fisher (1933), Kindleberger (2000), Tobin

12 This view, which has its antecedents in Kindleberger (2000) and Minsky (1982), emphasizes the cumulative process of financial imbalances and the possibility that such imbalances may cause sharp, debilitating adjustments or crises, which could generate equally sharp, and probably unanticipated, deflation. 
(1975), Bernanke (1983), Koo (2003), von Peter (2004)). In such a case, the interaction of the policy regime, the vagaries of human psychology and the economic environment would conspire to generate a perverse disequilibrium. And, of course, such developments would have the potential of distorting the monetary transmission mechanism, which in turn would have implications for velocity.

Credit cycles, often associated with excessive leveraging of financial assets, appear to be empirically linked to the incidence of booms and busts (Borio and Lowe (2002a, 2002b, 2004), Borio and White (2004)). In one variant of the view, an initial productivity boom would engender overconfidence amongst various agents in the economy. Loan demand would rise rapidly as confident investors reach for higher and higher perceived risk-adjusted yields. The early stages of such a boom might be self-reinforcing as perceptions of risks became increasingly exuberant. Credit supply would also be spurred on as risks would appear, at least initially, low. If the boom continued, and the optimistic scenario materialized, all might be well. But, if the productivity gains disappoint the high expectations, the economy would likely retrench. And, if leverage were sufficiently excessive, the retrenchment could cascade into a self-reinforcing contraction. Price pressures would likely fall as inside money would plummet. Real debt service burdens would increase, asset qualities would decline, bankruptcies would inevitably ensue and the potential for banking and financial crises would arise. Although these types of forces have been experienced in the distant past, they have also been relevant in the past decade. In some sense, such boom and bust cycles may be thought of as a permanent feature of the policy environment going forward (Borio, English and Filardo (2004)).

For good reason, the general consensus among policy makers and economists is that deflationary spirals should be avoided. The empirical question is how best to avoid them. For insights into answers to this, as well as to other important questions, we turn to the historical record.

\section{LOOKING BACK AT THE HISTORICAL RECORD}

We argue that, historically, deflation was viewed in a more positive light. The reason why, we believe, reflects the experience in the pre-World War I deflationary environment and beliefs about the importance of having a strong nominal anchor to maximize private sector performance. We note with some cautious optimism that the recent inflation and output behavior in the United States, amongst others, may indicate the emergence of a sea change in thinking about the true costs and benefits of price stability. Even though deflation may be a lower target than most would be comfortable with at this time, recent inflation outcomes especially when factoring in a statistical bias - are much lower than some would have thought prudent just a decade ago.

In this section, we examine both the historical and statistical record to understand the costs of deflation. One important advantage in looking to the experience of the distant past is that it provides a clearer perspective on deflation behavior. In history, deflation has often coincided with robust economic growth (Table 2). ${ }^{13}$ This is in sharp contrast to the conventional wisdom that generally is drawn from a more limited focus on deflation in Japan in the 1990s and

13 See Atkeson and Kehoe (2004), Bordo, Landon-Lane and Redish (2004), Bordo and Redish (2004), and Borio and Filardo (2004) for alternative ways to measure the positive association between output and deflation. 
deflation episodes in the Great Depression. This section takes a closer look into historical deflations to better understand the determinants of the different types of deflation.

\subsection{Historical narrative: evidence from the nineteenth century}

As we discussed above, the historical record is a comparatively fertile environment to study deflation because price level declines were much more frequent in the long century ending with 1914. Alternating waves of inflation and deflation were an integral part of the commodity-based classical gold standard regime with a general tendency for falling prices from the 1820 s to the mid 1840s; then rising prices following the Californian and Australian gold discoveries in the late 1840s until the early 1870s; then deflation from 1873 to 1896; and finally inflation from 1897-1914 following gold discoveries in South Africa and Alaska. This section explores some historical episodes of different types of deflation in the nineteenth and twentieth centuries.

\subsubsection{3-1896: a good deflation that turned somewhat bad}

The 1873-1896 episode is a clear example of a "good deflation" when prices fell in many countries by about $2 \%$ per year, accompanied by growth of about $2-3 \%$ per year (Bordo, Landon-Lane and Redish (2004)). Deflation in that era was driven by both a productivity boom (reflecting the "second industrial or mechanical revolution and the proliferation of railroads across the world (Crafts (2000)), and by a number of major countries (Germany, Netherlands, Belgium and Scandinavia in the early 1870s and France later) joining the gold standard.

Although secular deflation was accompanied by positive growth, it was controversial because of its distributional consequences. Groups whose real incomes fell, such as debtors, farmers or those whose real incomes were perceived to have fallen in an age before price indices, complained bitterly and engaged in often disruptive social and political agitation. ${ }^{14}$ In the United States, this was manifested in the free silver movement and the rise of organized labor. In Europe it appeared in the growth of both labor unions and labor political parties and in a demand for tariff protection by agricultural groups.

Although real output grew on average in the deflation episode of 1873-1896 in most countries, growth was punctuated by several recessions (1873-1875, 1884-1885, 1890-1896), the worst of which was the last - which may even possibly be characterized as bad. It began with the Baring Crisis of 1890 when Argentina defaulted on its debt. This shock led to banking crises (and stock market crashes) in London, elsewhere on the continent and the United States and other parts of Latin America, especially Brazil (Bordo and Murshid (2003), Triner (2003)). Recession was further aggravated by a wave of banking panics which began in the United States in 1893 and spread to Europe (especially Italy) and Australia (Bordo and Eichengreen (1999)).

\subsubsection{7-1843: bad deflation}

An earlier nineteenth century episode of deflation from 1837-1843, often viewed as bad, began with financial crises in London and the Continent (Kindleberger (2000)) and especially in the United States in 1837. Another wave of crises occurred in 1839. In the United States,

14 Discontent seems to have been less when nominal wages continued to rise than when they fell, although real wages rose in both circumstances (Friedman and Schwartz (1963)). 
debate still swirls over whether the crisis and deflation reflected the "Bank War", the struggle between President Andrew Jackson and Nicholas Biddle, President of the Second Bank of the United States (an early central bank) (Rousseau (2003), Wallis (2003)) or events in Europe such as a series of bad harvest failures in England, which led to the importation of wheat from the continent and a drain on the Bank of England's gold reserves leading it to raise its discount rate and precipitate capital flight from periphery countries, especially the United States (Temin (1969)). ${ }^{15}$ The annual data for this period may be subject to some questions about their accuracy. For example, although prices fell by $5.6 \%$ in the United States, $2.1 \%$ in the United Kingdom and 2.0\% in France, narratives by contemporary observers viewed the episode as one of serious recession (Thorp (1926)). Available measures of real GDP show an increase in the United States of 3.9\% and of 1.3\% in France. The United Kingdom, in contrast, experienced a real GDP decline of $2.6 \%{ }^{16}$

\subsection{Historical narrative: evidence from the twentieth century}

\subsubsection{9-1921: bad, possibly ugly for some, deflation}

During the immediate post-World War I period, there was a short period of downward price movement in many countries that corresponded with a global contraction in economic activity. For example, annual GDP fell on a peak-to-trough basis by $18 \%$ in the United States, $29 \%$ in the United Kingdom, 20\% in Germany, 24\% in Canada. Moreover, these years were also accompanied by considerable volatility in output. ${ }^{17}$ Given the poor output performance, these deflations would be characterized as "bad". The serious recession and deflation, many would argue, was engineered by tight monetary policies followed by the Federal Reserve, Bank of England, Banque de France and other monetary authorities in countries dedicated to rolling back the high inflation created during World War I and restoring the pre-war gold parity. The expectations of such policies and their likely effects also contributed to the deflationary environment. The collapse in aggregate demand appeared mostly in falling prices, which had increased rapidly during and after the war as a consequence of both wartime scarcity and speculation. It is, however, interesting to note that although real output declined significantly, the decline was not out of line with the experience of earlier severe cyclical contractions (Zarnowitz (1992)). ${ }^{18}$

15 It is also useful to note that Jackson, a populist, strongly opposed the Second bank under Biddle for its alleged monopoly power over the US banking system.

16 Without a doubt, the farther one pushes back in history, the less confidence one should have in data for GDP. However, using industrial production estimates from Davis (2002) for the United States corroborates that there is little evidence of a significant production slowdown during this period.

17 At a higher data frequency in the United States, for example, the unemployment rate rose from $4 \%$ in 1920 to $12 \%$ in 1921, and industrial production fell 23\% (Meltzer (2003)); at the same time, the GNP deflator fell $28 \%$ from peak to trough (based on quarterly data from Balke and Gordon (1986)).

18 To be sure, demobilization could have contributed to the severity of the recession. Further analysis of this episode is left for future research because of the difficulty of parsing out the various post-war demobilization effects from the policy effects. In addition, the volatility and short duration of the episode complicates the analysis using annual data. 


\subsubsection{1-1929: good deflation}

The 1920s period represents an example of a good deflation, preceded, as discussed above, by serious recession in many countries in 1919-1921. The rest of the twenties - "the roaring twenties" - observed rapid real growth in many countries (with the principal exception of the United Kingdom mired in a 20-year stagnation) punctuated by two very mild recessions. The period also exhibited mild deflation of $1-2 \%$. Many attribute the 1920 s prosperity to a postwar recovery and the proliferation of new "high tech" industries such as automobiles, telephones, radios and refrigerators (White (1990)); Graph 1 illustrates the importance of positive supply shocks during this period. The resolution of the post-war reparations and war debt problems in the late twenties, the renewal of international trade with the end of post-war restrictions and the renewal of international capital movements after the major belligerents stabilized their currencies and the gold exchange standard was restored in 1925, and extensive direct and portfolio flows from the United States to Europe (especially Germany) and to Latin America played important roles in spreading the prosperity worldwide (Bordo, Eichengreen and Irwin (1999)). ${ }^{19}$

\subsubsection{9-1933 (the Great Contraction): an ugly deflation}

The contraction of 1929-1933 was characterized by both drastic declines in real output (for example, United States $-7.6 \%$, Canada $-8.4 \%$, Germany $-2.7 \%$, United Kingdom $-1.0 \%$ and France $-2.2 \%$ ) and deflation (United States $-6.8 \%$, Canada $-6.2 \%$, Germany $-5.7 \%$, United Kingdom $-3.8 \%$ and France $-4.4 \%$ ). Indeed, the size of the output decline associated with this episode was generally much larger than comparable deflations during other periods (Graph 2). In addition, more of the contraction of aggregate demand went into output than into prices and nominal wages than in 1919-1921, reflecting in large part the presence of important structural rigidities (Bordo, Erceg and Evans (1997), Hanes and James (2001), O’Brien (1989)).

A voluminous literature exists on the episode. The current consensus view is that the contraction was caused by monetary forces in the United States. The Federal Reserve began tightening monetary policy in early 1928 to help moderate the Wall Street stock market boom which had been underway since 1926. The Federal Reserve was wedded to the real bills doctrine which proscribed bank lending to finance speculative activity (Meltzer (2003)). Deflationary pressure was enhanced by the Banque de France which was following a deliberate gold sterilization policy of gold inflows induced by France's return to the gold standard in 1926 at a greatly depreciated and undervalued parity (Eichengreen (1992)). Tight money then precipitated a recession beginning in August 1929 and the stock market crash in October. Most commentators today believe that the crash was not the main cause of the Great Contraction which followed (Friedman and Schwartz (1963), Romer (1992)) but it did contribute heavily to the first years of serious recession, 1929-1930. The transformation of a serious recession in the United States in 1929-30 into the Great Contraction is universally attributed to a series of banking panics beginning in October 1930 which were unchecked by expansionary Federal Reserve actions (Friedman and Schwartz (1963)). ${ }^{20}$

19 Sargent (1986b) points to the Poincaré miracle as evidence that sound monetary and fiscal reforms during the time allowed France to engineer a relatively costless stabilization of prices, returning the country to the gold standard albeit at an $80 \%$ depreciation of the Franc.

20 The Friedman and Schwartz hypothesis has been supported over the years by considerable research. Bordo, Choudhri and Schwartz (1995), for example, present simulations which show that had the Federal Reserve followed expansionary monetary policies to offset the effects of the banking panics on money supply that the great contraction could have been avoided. A recent paper by Christiano et al (2004) which is based on 
The contraction was then transmitted to the rest of the world via the fixed exchange rate linkages of the gold standard and by "golden fetters" which prevented the monetary authorities of gold standard adherents from following the expansionary policies needed to offset collapsing demand and a rash of banking panics across the world (Bernanke and James (1991)), without triggering a speculative attack on the gold parity (Temin (1989), Eichengreen (1992)).

The Great Contraction ended by 1933 in most countries except the gold bloc (France, Belgium, the Netherlands, Switzerland, Italy, Poland and Czechoslovakia) which suffered depression until they left gold in 1935-1936. Once countries cut the link with the gold standard, they were able to follow expansionary monetary policies to reflate and recover (Bernanke (1995), Choudhri and Kochin (1980), Eichengreen and Sachs (1985), Eichengreen (1992), Temin (1989)).

The process began with the United Kingdom leaving gold in September 1931 followed by two dozen other countries linked to sterling. The United States suffered depression until March 1933; recovery involved expansionary gold purchases by the US Treasury and devaluation of the dollar.

Debate continues over the propagation mechanisms of the contraction in the United States, whether it was via sticky nominal wages (Bernanke and Carey (1996), Bordo, Erceg and Evans (2000)), financial disintermediation (Bernanke (1983)), rising real interest rates (Schwartz (1981)), and debt deflation (Fisher (1933)).

The experience of the Great Contraction has colored subsequent views on deflation but the historical record suggests that it is "sui generis". There is no clear cut evidence on the role of deflation in making the Great Contraction great. We do not know conclusively if falling prices worsened the recession via Irving Fisher's (1933) debt deflation process (Bernanke and James (1991)) or whether the problem was that prices did not fall enough to clear markets as seems to have been the case in 1919-21. Thus in our work we do not place the Great Depression at center stage in our analysis of deflation but rather we focus on the other experiences with deflation because we view the Great Contraction as special.

\subsubsection{7-38 and 1948-1949: 2 episodes of bad deflation and the zero nominal bound}

Meltzer (1999) documents two recessions in US history characterized both by falling prices and by extremely low interest rates. The recession of 1937-38 was one of the most severe recessions of the twentieth century, characterized by an $18 \%$ decline in GNP from peak to trough and the unemployment rate reaching 20\%. Prices declined about $5 \%$ from the quarterly GNP deflator peak in the third quarter of 1937 to the trough in the second quarter of 1939. It was triggered, according to Friedman and Schwartz by a doubling of reserve requirements by the Federal Reserve, beginning in 1936. Other factors include a tight fiscal policy stance by the Roosevelt administration. Short-term interest rates in this episode ranged between $0.03 \%$ and $0.5 \%$. Meltzer demonstrates that real interest rates and the real monetary base were highly correlated in this episode reflecting the common influence of deflation.

simulations of a dynamic stochastic general equilibrium (DSGE) model of the US economy in the Great depression reaches the same conclusion. Moreover, Bordo, Choudhri and Schwartz (2002) and Hsieh and Romer (2001) present evidence that the Federal Reserve would have been able to follow these expansionary policies without being constrained by its gold reserves as had been argued earlier by Eichengreen (1992). 
Real interest rates were perversely related to the evolution of real output whereas movements in real money balances seem to explain well the pace of both recession and recovery. This evidence, he argues, strengthens the case for using monetary aggregates as the major policy instrument when interest rates reach the zero lower bound for nominal interest rates. A similar pattern is observed in the much milder post-World War II recession of 1948-49 which also exhibited falling prices with short-term rates still pegged close to zero. Again, movements in the real base track the real economy whereas real interest rates do not.

\subsubsection{Modest deflation in the mid-twentieth century}

In the immediate post-World War II era and 1950s, several countries exhibited some proclivities toward very short periods of deflation. In general, the episodes were short-lived when compared to the interwar or pre-1914 period. This may have been a normal aspect of cyclical experience over most of the period before World War II when business cycles typically showed both output and price levels moving procyclically (Cagan (1979), Zarnowitz (1992)). After the mid-1960s, however, we observe a positive price trend in most countries, and, over the business cycle, the pattern of price movements has changed from procyclical levels to procyclical inflation rates. It is only since the return to a low inflation environment in the past 15 years, similar in many respects to the environment that prevailed for much of the preceding century and a half, that the spectre of deflation has reemerged.

\subsubsection{Summary: the historical setting in which deflations occur}

Most of the historical deflationary episodes that we document occurred under some variant of the gold standard. Moreover, the episodes of deflation that occurred in fiat money regimes were during periods of postwar resumption to the gold standard.

Under the gold standard, deflation was generally of the good variety reflecting positive aggregate supply shocks. When they turned bad it was mainly because of banking crises aggravating the effects of negative aggregate demand shocks. Such crises in large part reflected the fragility of early banking systems (and financial markets) in an environment of asymmetric information, poor governance and, above all, the absence of a lender of last resort. Such episodes generally ended when the forces driving the crisis naturally subsided or when some lender of last resort intervened.

Bad deflations were also associated with disinflations after various wars when monetary authorities following the classical orthodoxy pursued the tight monetary and fiscal policies needed to return to gold convertibility at the original parity. Such episodes occurred twice in British monetary history, after the Napoleonic wars (Bordo and White (1991)) and, as mentioned above, after World War I. In the United States, this was also the case in 1920-21. However after its Civil War, apart from a deliberate contractionary policy which lasted a year following the Contraction Act of 1866, the twelve years of deflation prior to the successful resumption on January 1, 1879 was best characterized as being benign, reflecting the US Treasury's pursuit of a policy allowing the real economy to grow up to a constant money supply (Friedman and Schwartz (1963)).

The deflation of the 1920s and 1930s were also associated with a variant of the gold standard - the interwar gold exchange standard, in which the world's fiduciary money supply was a multiple of the gold base. The money-to-gold multiplier in each country was the product of the ratio of international reserves (gold reserves plus foreign exchange) to gold reserves, the ratio of the monetary base to gold, and the money multiplier (the ratio of money supply to the base). As Bernanke (1995) demonstrates, this leveraged situation increased the 
danger for a drastic deflation as did occur from 1928 to 1933. The massive world wide deflation, according to him, reflected the confluence of three key forces which were alluded to in section 3.2.2: a scramble for gold as authorities liquidated foreign exchange reserves, a contraction of the monetary base to preserve gold and disintermediation by the banking system.

There seem to be very few historical episodes of deflation under a fiat money regime which were not in any way linked to a commodity nominal anchor. Sweden successfully followed a price norm in the 1930's, gearing its monetary policy to stabilize a price index. In many respects, this was an attempt to mimic the price stabilization features of the gold standard while eliminating the volatility produced by shocks to the gold market, as advocated by Fisher, Wicksell and Marshall (Bordo (1984), Berg and Jonung (1999), Fregert and Jonung (2001)). Presumably, a credible commitment to such a policy could anchor expectations in a way similar to adherence to a commodity standard. Whether the recent deflationary experience can be characterized as a serious source of concern may reflect, among other things, the extent to which the nominal anchor is perceived to be as strong as was the case under the pre-1914 gold standard.

\subsection{Statistical analysis of deflation}

\subsubsection{Deflation episodes}

Table 2 presents statistics from past deflationary episodes, focusing on the size of the price decline from peak to trough, the duration of each episode and the size of the largest one-year decline during each episode. In contrast to Table 1 which provided an analysis of deflation with an annual frequency, this table emphasizes more persistent deflationary episodes.

In contrast to the pattern exhibited in recent decades, long periods of deflation were fairly prevalent. The mean peak-to-trough decline for these episodes was $-4.2 \%$. The average duration was 5.4 years. What is particularly important to note is that some of the annual declines in the price level were rather large - in many cases, double digit one-year declines were not uncommon. Of course, the average bundle of consumer goods a century or so ago was relatively dominated by commodities rather than services as is true today. As a consequence, the wide price swings of the past may be more of a reflection of the consumption basket of the past than an indication of the magnitude of price volatility to be expected in today's low inflation environment.

The table also shows quite clearly that deflation episodes were not always associated with a contraction in output. In fact, deflations associated with output contractions were rather rare. Graph 2 highlighted this stylized fact and showed that deep deflations were mostly concentrated in the Great Depression period. Nonetheless, the extreme experiences of the Great Depression arguably still shape - rightly or wrongly - the concerns of the public and policymakers.

\subsubsection{Asymmetric persistence of deflation and inflation}

Table 3 shows that inflation persistence was generally low in the early period, rose significantly in the twentieth century and then recently fell. This hump-shaped time-series pattern is consistent with the unit root tests on the historical data; the nineteenth century and early twentieth century inflation data exhibit stationarity, the Great Inflation period is consistent with more persistent changes in inflation rates as would be suggested by a unit root 
process, and in the past decade there is some evidence that inflation rates have generally become more stationary. ${ }^{21}$

This low-persistence behavior in the distant past was, of course, consistent with the monetary regime implied by the gold standard, both for the core and periphery countries. ${ }^{22}$ Any bursts of inflation or deflation were naturally reversed in short order because of the rules of the game. And, the recent time-series behavior of inflation, as well as the greater frequency of deflation, suggests that the current monetary policy environment has begun to resemble more that of the distant past than that of the past 40 years.

Another informative comparison of the time-series behavior of persistence addresses whether the size of persistence is deflation dependent. Was transitory deflation more persistent than transitory inflation, as theories emphasizing nominal rigidities would suggest? If downward nominal rigidities were significant in a macroeoconomic sense, an initial deflation would interact with the rigidities to draw out the economic adjustment compared to a similiarly-sized inflation. To test this possibility of asymmetry, a threshold autoregressive (TAR) model of inflation $(\pi)$ is adapted from Enders and Granger (1998).

$$
\Delta \pi_{t}=\beta+I_{t} \rho_{1} \pi_{t-1}+\left(1-I_{t}\right) \rho_{2} \pi_{t-1}+\varepsilon_{t}
$$

where $I_{t}$ is a (heaviside) indicator function defined as $I_{t}=\left\{\begin{array}{l}0, \text { if } \pi_{t-1} \geq 0 \\ 1, \text { if } \pi_{t-1}<0\end{array}\right.$.

We find little evidence to suggest that deflation was any more persistent than inflation for the pre-1913 period (Table 4). The mean value of the persistence parameter for all the countries in the sample during deflation periods is 0.05 versus 0.15 during inflationary periods. So, if anything, the persistence during deflations was less than the persistence in inflations. One interpretation of these results is that there is little role for downward nominal rigidities, at least during the pre-1913 period. This would also suggest that to the extent that downward nominal rigidities were not important, modest deflations during this period were likely to be no more costly than modest inflations. ${ }^{23}$

Applying this interpretation to the current monetary policy environment may be subject to many caveats because of obvious differences in the economic environments then and now. For example, some of the differences would include the nature of wage and price rigidities, the importance of debt deflation and the nature of the anchored inflationary expectations. To examine the possible implications for the current period, we apply an analogous method to the Great Inflation period with one key difference. Rather than focusing on periods of inflation and deflation, we examine periods when inflation was above and below its trend. Somewhat surprisingly, the results in Table 5 are rather similar to those in Table 4 . The hypothesis tests generally show that negative and positive deviations of inflation around trend exhibit

21 These results are consistent with those of Borio and Filardo (2004), which provides various alternative snapshots of the persistence of inflation in the historical record.

22 See also Burdekin and Siklos $(1999,2004)$ for further detail on some of the differences between the core and periphery countries.

23 Applying these same methods to the immediate post-World War I period is complicated because episodic nonstationarities or other data problems: hyperinflation in some countries, adverse effects of price controls in others during the 1930s and 1940s and some missing data. Some of these factors may be responsible for generating behavior consistent with unit roots. In general, for the cases where the data are less likely to have been unduly influenced by episodic nonstationarities, the evidence for asymmetry is weak. 
symmetric persistence. If anything, positive deviations, again, are more persistent than the negative ones. The mean persistence is 0.33 for negative deviations and 0.54 for positive deviations.

\subsubsection{Further investigations into asymmetry}

We check the robustness of the symmetry results in the country-by-country analysis for the gold standard period using panel estimation methods. Table 6 summarizes the results from two groupings of countries. The first grouping is the United States and the United Kingdom. The quality of the data is likely to be the highest for these countries. They also represent two key economies in the gold standard period. The second grouping is for the G10 countries. This provides a larger sample with which to improve the accuracy of the analysis. Another key difference between this test and the previous one is that we include additional regressors that may alter our interpretations of the key factors influencing inflation. ${ }^{24}$

The statistical model of inflation is

$$
\pi_{i, t}=K_{i}+\rho_{1} I_{i, t} \pi_{t-1}+\rho_{2}\left(1-I_{i, t}\right) \pi_{t-1}+\beta X_{t-1}+\varepsilon_{i, t},
$$

where the model is estimated using a pooled regression (unbalanced panel). In this equation, $\pi$ is the annual inflation rate in country $i, K_{i}$ is a country specific constant, and $X$ are a set of economic variables associated with inflation determination. $I_{t}$ is a heaviside indicator function as defined above. The error term is assumed to be distributed normally.

The estimation methodology is straightforward. If the country constants were statistically different at the 95\% confidence level, we estimated the model with fixed effects; otherwise, we used a common constant. In nearly all the cases, we could not reject the hypothesis that all the country constants were equal to each other. This should not be a great surprise given the nature of the gold standard and its strong nominal anchor on all the countries under consideration.

The hypothesis of symmetry of the inflation process was tested again by comparing $\rho_{1}$ and $\rho_{2}$. The evidence is quite clear for both groupings: there is no statistically significant evidence that the inflation process is asymmetric. This suggests, as noted above, if there were downward nominal rigidities at the microeconomic level during the gold standard period, they did not exhibit a macroeconomic impact on the inflation process. ${ }^{25}$ The other regressors, $X$,

24 One might interpret this as a reduced form Phillips curve specification.

25 In this sense, these results would be consistent with those in Lebow, Wascher and Stockton (1995) where they cannot find statistically-significant evidence of nonlinearity of the type that would be implied by the downward nominal rigidity model of Akerlof et al (1996). Such evidence is supported more generally. McLaughlin $(1994,1999,2000)$ argues that standard wage skewness measures may be poor reflections of the degree of downward wage rigidity. Using the Panel of Income Dynamics, he finds that there is little thinning of the wage change distribution below zero in the United States. Using a different criterion, Kimura and Ueda (2001) found scant evidence of downward wage rigidity using Japan's Monthly Labour Survey data through 2000 - even though such rigidity was evident in an earlier study with a different dataset. This evidence suggests that there might not be particular gains to targeting a positive inflation rate in order to "grease the wheels". In contrast, other research by Kuroda and Yamamoto (2003), Lebow, Stockton and Wascher (1995), Altonji and Devereux (1999) and others have found some evidence of downward wage rigidity. In general this is an important issue, but it should be pointed out that these studies also find evidence of nominal wage cuts and an increased likelihood of wage cuts as the inflation rate declines. Whether the skewness of wage distributions is sufficient to have meaningful macroeconomic consequences remains an open question, the recent experience suggests that rigidities might not be as important as once thought, in part because of lower 
included in the regression are the first lag of the country-specific annual growth rate of money, the output gap, supply shocks, demand shocks, a banking crisis variable and the annual growth rate of real equity prices (see footnote in the table for further details). In general, they have plausible, economically-meaningful signs, with the lagged of the money growth variable being the most significant. Their inclusion did not change the robustness of the symmetry result.

\subsubsection{Statistical determinants of the good, the bad and the ugly deflations}

This section investigates the determinants of the good, the bad and the ugly deflations as a means to delve further into the nature of deflation in the distant past. Using information from both the historical narratives and the quantitative measures from the historical dataset, each deflationary episode in Table 2 is classified as being either a good, bad or ugly deflation. ${ }^{26}$ This classification is then analyzed using an ordered probit model, employing various economic factors that might help to distinguish the conditions most likely to produce one of the types of deflation. It is important to note that deflation in this model is a persistent peakto-trough decline in aggregate prices.

In the empirical model, the dependent variable can take one of three values which correspond to the deflations that were categorized into the three types of deflation:

$$
\Lambda_{i}=\left\{\begin{array}{l}
0, \text { good deflation } \\
1, \text { bad deflation } \\
2, \text { ugly deflation }
\end{array}\right.
$$

Assuming a latent variable formulation of the model, the latent variable $\lambda^{*}$ is described in terms of observable variables $\mathrm{X}$ as

$$
\lambda^{*}=X \beta+e
$$

where $e$ is assumed to have a Normal distribution with a mean of zero and a given standard deviation (see Appendix for further details). In this way, the probability of being in the good, the bad and the ugly deflations can be easily assessed given observations on $X$.

The observable variables, $X$, are chosen based on availability and on their relevance in possibly playing a role in determining whether a particular deflation will be of the good, the bad or the ugly type. They include monetary aggregates, the percent deviation of the price level from a steady-state price level $\left(\mathrm{P}^{*}\right)$ based on the quantity theory, a banking crisis indicator variable, supply and demand shocks estimated using a Blanchard-Quah decomposition described in the previous section, real wage inflation, interest rates and the growth rate of real equity prices.

To emphasize the lead-lag distinction between the regressors and the indicator of deflation types, we use five-year averages of the observable variables prior to the start of the deflation.

inflation rates and also because of less union power in labor markets. Looking farther back in time, Hanes (1993) finds that nominal wage flexibility generally fell since 1880 . This raises the possibility that the costs of deflation were smaller during the gold standard period.

26 The classification was based primarily on the peak-to-trough output losses during each episode, and then cross-referenced with the historical narratives. In general, double-digit declines were necessary but not sufficient condition to qualify as "ugly"; those episodes with declines not categorized as ugly were considered "bad". 
In this way, we minimize the possibility of reverse causation. In the case of banking crises, for example, we rule out the possible feedback from debt deflation to banking crises because we only take account of banking crises that precede the peak in the price level.

While the explanatory variables have various possible interpretations as to their economic significance, we would like to highlight our views of what the (lagged) explanatory variables might be explaining. The monetary aggregates and the $\mathrm{P}^{*}$ variables capture a monetarist view of the inflation process. The rapid growth of the monetary aggregates in the period before a price peak is likely to put upward pressure on prices and, as a result, on the gold parity constraint. The adjustment process during the gold standard period would generally generate conditions fostering deflation. Likewise, the gap between the price level and $\mathrm{P}^{*}$ before a price peak could be capturing deviations of prices from the nominal anchor and would likely prompt an adjustment over time; the larger the gap, the sharper the likely adjustment. Supply and demand shocks are closely related to possible channels determining whether a deflation is good or bad, as argued above. Real wage inflation, while reflecting supply and demand conditions, could serve as a proxy for nominal rigidities; if nominal wages exhibited downward nominal rigidities, high real wage growth would likely exacerbate the subsequent adjustment process. The interest rate could also be picking up some cross country differences in financial conditions vis-à-vis the underlying monetary conditions implied by the gold standard. The banking crises variable offers a measurement of the possible link between deflation and financial crises.

The results are generally supportive of the monetarist view that monetary conditions are important determinants of the different types of deflation (Table 7). On the one hand, the cross-sectional bivariate correlation between money growth and the probabilities of the good, the bad and the ugly deflations is not particularly high at .04, but is statistically significant at the $95 \%$ confidence level. Its (pseudo-) $\mathrm{R}^{2}$ is fairly low at $5 \%$. On the other hand, the $\mathrm{P}^{*}$ gap appears to be an important determinant of the different types of deflation, especially when the banking crisis indicator is included in the estimated model. Model 3, for example, explains $24 \%$ of the cross-sectional variation, and the model parameters are significant at the $95 \%$ confidence level. These variables generate consistent correlations for nearly all the relevant specifications in the table. It is also useful to examine the in-sample fit of the models. The middle panel provides such information. In general, the $\mathrm{P}^{*}$ and banking crisis variables account for many of the good deflations - since the crisis variable is generally 0 for the good deflations, this suggests a particularly strong role for the $\mathrm{P}^{*}$ variable. In addition, it is useful to examine the results of models 7 and 9 when the number of deflation episodes falls to just under two dozen. In these cases, the role of the real wage growth and real equity prices has less to do with their explanatory power than with the fact that data availability cuts down the number of useable data points. The bottom line is that the $\mathrm{P}^{*}$ and crisis variables are able to explain at least two dozen deflationary episodes quite well.

One way to gauge the importance of the crisis variable is to examine its marginal effect of the probability of being in the good, the bad and the ugly deflations. In the bottom panel, we look at the marginal effect in model 4 . The results are striking. If there is no banking crisis, the probability of the good, the bad and the ugly deflations are $.93, .06$ and .01 respectively. If a crisis, the probability of a good deflation drops dramatically to .38 , while the probabilities of a bad and ugly rise considerably.

The other explanatory variables in the table provide marginal predictive content but, in general, the contribution is not statistically significant. The coefficients have intuitively plausible signs. For example, the bigger the supply shock, the more likely a good deflation would occur (hence the negative coefficient). The greater the increase in demand shocks and real wages, all else the same, reduces the likelihood of a subsequent good deflation, a result 
consistent with cyclical price behavior. Equity prices have the same sign as the supply shocks, suggesting that real equity prices may reflect the likelihood of a favorable supply side phenomena, and hence raise the likelihood of a good deflation. But, as mentioned above, the statistical significance of these variables is rather low, especially when compared to the $\mathrm{P}^{*}$ and banking crisis variables.

\subsubsection{Deflation and the zero lower bound for nominal interest rates}

The historical record on interest rates offers some interesting, yet in many ways troubling, stylized facts. A robust finding from looking back at nominal interest rates is that rates were remarkably stable despite wide swings in inflation/deflation. This is true across countries, across different levels of financial maturity, across maturities of interest rates and across time during the pre-interwar period. Graph 3 illustrates these stylized facts. Great Britain and France surely had some of the most developed financial markets during the $19^{\text {th }}$ century. Norway and the United States were emerging market economies early on but later caught up. The story looks very similar for short-term and long-term rates across all these experiences interest rates simply did not vary much.

The historical record on interest rates also has implications for other aspects of the conduct of monetary policy. As is discussed elsewhere, the stability of nominal interest rates in the face of wide swings in inflation/deflation is closely related to the long literature on the Gibson paradox - the finding that nominal interest rate movements were more correlated with the price level than with the rate of inflation during the nineteenth and early twentieth centuries. ${ }^{27}$ Explanations for such behavior generally rely on sluggish expectation updating (Klein (1975)), which is related to the "information technology" during the distant past as well as the incentives inherent in the gold standard regime to generate mean-reverting inflation expectations. ${ }^{28}$ If true, then the return to a stronger nominal anchor as has been the trend in the past decade may usher in a new era of more sluggish expectation formation, which could have important implications for the stability of empirically-oriented Taylor-type interest rate rules for monetary policy making as well as of velocity of the monetary aggregates.

Of additional importance to our discussion is the fact that nominal interest rates rarely hit the zero lower bound for nominal interest rates in the pre-war and pre-interwar periods, again despite evidence of periods with quite steep deflation rates. This implies that liquidity traps were not of prime importance during these periods. Of course, the 1930s as well as recent experience in Japan and Switzerland provide ample evidence that nominal interest rates can fall quite low and in many cases hit the zero lower bound for nominal interest rates (English

27 Friedman and Schwartz (1982) and Cagan (1984) provide a detailed review of the issues, highlighting the empirical investigations into the Gibson paradox.

28 The information technology argument is described in Borio and Filardo (2004). In addition, the historical record suggests that the speed of expectation updating was a function of the inflation regime. Regimes with low credibility such as the regime during the Great Inflation would provide incentives for rapid updating; to not do so would be very costly. Regimes with high credibility and a strong nominal anchor would provide incentives to update less frequently. This view is consistent with the recent empirical evidence presented by Bordo and Haubrich (2004) indicating that term structure spreads are poorer predictors of recessions during more credible monetary regimes. In addition, the importance of the regime is corroborated using a less model-dependent approach by the fact that returns on gold bonds (ie bonds that paid off in gold) never diverged much from the returns on paper bonds during the Greenback inflation/deflation episode following the US Civil War, during which the price level doubled and subsequently halved (Freidman and Schwartz (1963)). 
(2000)). ${ }^{29}$ This evidence does not necessarily imply the existence of liquidity traps, however, because the zero bound is only a necessary but not sufficient condition for the existence of a liquidity trap. On this issue, the historical evidence suggests that the presence of liquidity traps is highly elusive. Indeed, Meltzer (1999) and Hanes (2004) have recently argued that in the 1930 s, in what is generally considered the prototypical example of a liquidity trap, the US in fact did not one. ${ }^{30}$

Moving from the facts to the more risky business of interpretation, if it is true that liquidity traps are sufficiently rare, the implication of the recent theoretical literature on monetary policy and liquidity traps takes on much less practical significance. Consequently, central banks may become persuaded that they need to be less wary about the prospect of ugly deflations and hence be less reluctant to lower their inflation targets. It also may mean that more conventional monetary policy instruments are sufficient to deal with a range of deflationary environments. We discuss the options in more detail in the next section.

\section{INFLATION, DEFLATION AND MONETARY POLICY: THE ZONAL APPROACH}

The historical record has provided a wide range of experiences from which to draw some conclusions about the usefulness of monetary policy. In this section we offer a new holistic approach to determining the appropriate monetary policy framework. In general, history shows that the appropriate framework depends on the inflation circumstances or, more precisely, the inflation zone in which a central bank finds itself. The zones span the spectrum from high inflation to deep deflation; for a visual summary of this view, see Graph 4 . We discuss each zone and its implications for monetary policy tradeoffs, in turn, emphasizing what we have learned from the historical record. It is also important to emphasize that to learn from history, we have to be careful about extrapolating linearly from the past to the present. In a sense, a corrective lens may be necessary at times to view the past clearly. In this section, we remain cognizant of some factors that may be useful in translating the lessons from the past for the future.

\subsection{Zone 1: high inflation}

Zone 1 is characterized by high and volatile inflation, as experienced in Latin America during much of the twentieth century, as well as in infamous European cases of hyperinflation during the interwar period. These episodes provide the clearest example of Friedman's dictum: inflation is always and everywhere a monetary phenomenon (McCandless and Weber (1995)).

The prescription to avoid or escape such circumstances seems simple enough - reduce and stabilize the growth rate of money. Such a simple policy has often been complicated by political pressures to raise revenues from monetary creation (the seigniorage motive). Hence, to keep high and volatile inflation from reappearing, successful monetary reforms have

29 Coenen, Orphanides and Wieland (2004) and Borio and Filardo (2004) offer simulations to suggest that the zero lower bound of interest rates is more likely when steady-state inflation rates fall. Even so, the evidence from counterfactual simulations suggests that the probability of hitting the zero lower bound in the pre-1914 period was quite low even if the preference for stabilization in the late twentieth century was in place in the distant past.

30 It is important to note that Meltzer (1999) follows up on the earlier study by Brunner and Meltzer (1968). Orphanides (2003) reinforces these findings by examining the minutes of the FOMC in the 1930s. 
generally gone hand in hand with fiscal reforms (Sargent (1986a)). Such monetary reforms historically have included provisions to slow the rate of money growth and to ensure more central bank operational independence. ${ }^{31}$

Moreover, a package of tight money and fiscal balance can be further enhanced if anchored by a credible commitment mechanism to stabilize inflationary expectations with the concomitant effect of stabilizing velocity. Words alone are not sufficient in such a zone. Words must be backed up with actions. History has shown how to design successful private and public arrangements. In the nineteenth century and the early twentieth century, arrangements included adhering to the gold standard (as was the case with the stabilizations in Europe in the 1920s), establishing a provision (by international loans) of gold or other hard currency reserves by a credible authority such as the Bank of England and the Federal Reserve, and, in the interwar period, the Bank for International Settlements. In addition, private sector solutions are possible and, in fact, have been used in the past. Private sector guarantees of international loans, for example, were offered by Rothschilds or JP Morgan both before and after World War I (Bordo and Schwartz (1999)). In the more recent period, IMF-backed reform programs have often played an important role in successful programmatic reforms leading to the elimination of high inflation.

\subsection{Zone 2: moderate inflation}

In the case of moderate inflation, such as characterized the experiences of the advanced countries in the 1970s and early 1980s, the prescription to improve outcomes is similar in spirit - tight, credible monetary policy. Two different strategies to achieve low inflation generally have been followed: monetary aggregate targeting and an interest rate approach, which in recent years has been tied to an inflation targeting framework.

In the former strategy, the central bank uses its policy tool (eg open market operations) to achieve a desired growth rate of some monetary aggregate consistent with achieving its inflation goal on quantity theoretic lines (eg Sargent (1986b)).

In the latter strategy, the monetary authority targets a short-term interest rate to achieve the desired inflation target, accounting for the influence of the real economy via the output gap as well as other variables. To achieve a successful strategy, the monetary authority must ultimately focus on the real interest rate, or else the policy could create unstable nominal conditions; one such necessary condition for stability is that nominal interest moves by more than the change in the inflation rate, which is sometimes referred to as the Taylor principle (Taylor (1999)). In a sense the modern approach is more akin to the Wicksellian approach in which the monetary authority targets the natural rate of interest (Woodford (2003)). ${ }^{32}$

31 The costs of large credible disinflations are estimated to be rather small (Sargent (1986a\&b)). Andersen (1992) and Ball (1994) provide additional cross-country evidence that the costs of disinflation (in terms of the sacrifice ratio) differ systematically with the size and speed of the disinflation and the extent of wage flexibility. Also see Siklos (1995) for a review of twentieth-century inflations and disinflations. Recently, Erceg and Levin (2003) argue that a policy of monetary contraction inevitably would lead to a (temporary) real contraction in the face of inelastic price expectations and nominal rigidities, but the more credibly perceived the commitment to restore price stability, the lower the sacrifice ratio. Credibility and the cost of disinflation would also depend on future political outcomes and economic shocks - developments which would be difficult to predict with precision. Such developments could also make it difficult to rule out a return to an unfavorable regime of the type seen in the past (Gagnon (1997)).

32 It took about a decade (1979-1992) for the United States, United Kingdom and other advanced countries to achieve this outcome. Doing so required following a preemptive policy on several occasions (eg 1994) to 
Higher levels of inflation have historically been associated with higher inflation uncertainty. Such volatility would naturally mean that ex ante and ex post short-term real interest rates would be quite volatile. This behavior would generally diminish the usefulness of interest rates as instruments and guides of monetary policy and would lead to a preference for monetary aggregate targeting. As inflation declined and credibility for low inflation increased, interest rate uncertainty would likely decrease and variation in the nominal short-term interest rate would largely reflect variation in real rates. This improvement bolsters the case for using a Wicksellian real interest targeting strategy at the lower end of the inflation range in this zone.

Also with disinflation, velocity would likely become less predictable in large part because financial innovation could play a more dominant role in its fluctuations, further strengthening the case for interest rate. Looking forward, if the pace of and nature of financial innovation were to have a more muted effect on velocity, it is conceivable that central banks would raise the weight of monetary aggregates in their conduct of monetary policy.

In this zone, a mixed monetary policy strategy makes good sense. The monetary aggregates arguably have provided a tried and historically true guide for monetary policy, if only to provide a broad mooring of the price level over time; arguably, the relationship between the monetary aggregates and inflation has been imprecise in the short run but has been fairly close over the medium run in many economies (Haug and Dewald (2004)). As history has shown, however, financial innovations have at times adversely affected the stability and predictability of velocity; even some of the recent instability has reflected the lingering vestiges of inefficient Great Depression-era regulatory constraints being lifted. To be sure, interest rate "rules" based on output gaps have had success as guides for policy, especially as inflation has become moderate or low. But, this does not suggest that the monetary aggregates should be completely ignored. Rather it suggests that relying both on the monetary aggregates and interest rate rules based on economic measures related to short-term price pressures as guides for policy has considerable appeal. The ECB's two-pillar approach is an example of such an approach (Issing (2001), Issing et al (2001), Masuch et al (2002)). ${ }^{33}$

\subsection{Zone 3: low inflation/price stability}

In this zone, with a credible nominal anchor in place, consumers, workers and investors would incorporate expectations of price stability, or low inflation, into their decision-making. They would also anticipate that departures of the price level from some reference value, or of inflation from the low desired inflation rate, would be transitory and hence would be expected to be offset by corrective monetary actions. In the historical case of the gold standard, the credible commitment to maintain the gold parity, except in cases of wartime emergency, firmly anchored expectations. In credible fiat currency regimes, an anchor could be

raise real rates above the prevailing nominal rate and in effect respond to an "inflation scare" (Goodfriend (1993), Orphanides and Williams (2003)).

33 The 2003 restatement of the ECB's policy strategy emphasized its two pillar approach. The pillars do not represent two approaches, per se, but rather complementary ways to assess the overall assessment of the risks to its price objectives. In particular, economic indicators of short-run price pressures are first analyzed and then cross-checked with the medium-term and long-term implication from the monetary aggregates. Issing (2002) offers an analysis of the deflation risk in the euro area which illustrates how a central bank may use the monetary aggregates to assess the monetary environment. For a dissenting viewpoint, see Galí et al (2004). For a more general discussion of some issues, see Viñals (2000). 
established as an implicit policy rule to achieve the monetary authority's inflation, or price level, goal.

In the current policy context, two important issues are how a central bank might best enter this zone and how the central bank might maintain it once it is achieved. For most advanced countries, the success in achieving low inflation environments over the past decade or so through, in many cases, a deliberate and gradual disinflation into this zone from zone 2 has meant that most of the discussion has revolved around its maintenance. The disinflation was achieved via tight monetary policies. Such policies led naturally to subpar growth at times, as the literature on empirical sacrifice ratios has emphasized. There is some evidence to suggest that the more credible and transparent the resolve of the monetary authority, the lower were the transition costs (Erceg and Levin (2003)). An alternative, the opportunistic approach may represent a lower-cost strategy (Bomfim and Rudebusch (1998), Orphanides et al (1997)). Under such a strategy, the monetary authority would wait patiently for a favorable price shock to materialize and produce a lower inflation rate. Once achieved, the maintenance of the low inflation/price stability zone is thought to require low-inflation vigilance where the monetary authority adopts a more symmetric approach to fighting both rising inflation pressures and declining inflation pressures.

An important potential policy concern that arises in this zone is the proximity of the zero lower bound for nominal short-term interest rates. If inflation were to fall low enough, possibly into deflation, a monetary authority would generally find it increasingly difficult to use short-term interest rates as an accurate measure of the stance of policy or as a reliable policy guide. Moreover, short-term policy rates could prove to be a poor means to communicate the policy intentions of the monetary authority. Again, the historical evidence from Meltzer (1999) underscores this point.

The problems with short-term nominal interest rates, however, should not be construed to mean that the monetary authority necessarily loses its room for maneuver. In fact, the historical record makes clear that the monetary authority may have ample room, especially if the financial sector is healthy. Moreover, the recent debate over the implications of the zero lower bound has emphasized the various options available for policy makers (Bernanke and Reinhart (2004), Yates (2003)). ${ }^{34}$ The monetary authority could adopt non-conventional measures to conduct policy such as targeting long-term interest rates, pursuing unsterilized foreign exchange intervention, adopting quantitative easing (by focusing on monetary targets) and purchasing goods and commodities outright. History suggests that the most time-tested means at the central bank's disposal is the expansion of the money supply via the monetary aggregates - both narrow and broad measures. By using open market operations to increase the reserves of the commercial banks, the central bank could boost aggregate demand and achieve its desired inflation rate (Lucas (2004)). ${ }^{35}$

34 They also highlight the use of communication strategies to shape interest expectations, central bank asset rebalancing to influence the relative market supplies of different types of debt securities, foreign exchange rates and the expansion of the monetary base. Andrés et al (2004) illustrates that imperfect asset substitution in a general equilibrium setting can provide an additional channel for monetary policy by operating on the long-term interest rate; the simulation results suggest at least a modest influence is available. McCallum (2000) describes how monetary authorities can use the exchange rate even when the zero lower bound is binding.

35 The recent academic debate on the monetary aggregates suggests that even at low levels of inflation the monetary aggregates are sufficiently correlated with inflation to be of importance in the conduct of monetary policy. This line of argument using new Keynesian models is most forcefully argued by Nelson (2003). Gerlach and Svensson (2003) also provide some evidence to suggest the $\mathrm{P}^{*}$ model might be useful in 


\subsection{Zone 4: low-to-moderate deflation}

The low-to-moderate deflation zone (roughly $0 \%$ to $3 \%$ deflation) might be viewed by some as the next logical step towards truly realizing the benefits of low inflation. Such an outcome would naturally build on the recent trend toward reducing inflation. Of course, achieving this would technically require tighter monetary policy. But more important, it would require the resolve to do so. Recent history raises doubts about the eagerness of central banks to pursue such a goal. In contrast to the distant past, policy makers have shown a reluctance to target deflation; if anything, monetary policy makers around the globe have generally perceived deflation as being undesirable. Nonetheless, as pointed out above, theory suggests that central banks may be able to increase economic welfare by reducing the inflation rate at least to true price stability-ie where the price level on average is flat. Some other theories suggest that the optimal inflation rate may be as low as somewhere near $-3 \%$. The attractiveness of the moderate deflation policy would depend on the empirical relevance of several important assumptions in the theories, not least of which includes the nature of downward nominal rigidities and the benefits of steady-state deflation.

This zone could present some additional complications arising from cyclical variation of price changes around the steady-state deflation rate. As discussed above, the zero lower bound for nominal interest rates would present complications for policy makers. And, of course, the closer the economy initially is to zero lower bound, the more likely the bound would be reached. The likelihood of reaching a zero nominal rate would depend on the steady-state deflation rate and on the type of shocks affecting the real interest rate. Negative demand shocks, for example, would likely generate both transitory declines in the real interest rate and disinflation. In this case, the zero lower bound for short-term nominal interest rates would more likely bind than if the steady-state inflation rate were higher. A similarly-sized supply shock would present less of a problem because of the tendency for the real rate to increase, and therefore offset the disinflationary effect on the probability of hitting the zero lower bound.

This suggests several possible policy options. Of course, the central bank could steer clear of the zero lower bound by choosing a higher steady-state inflation rate - something in zone 2 or 3. The cost of this choice would be the foregone stream of benefits from the lower inflation rate. Alternatively, the central bank could rely more heavily on quantitative measures of monetary policy rather than on short-term interest rates to guide monetary policy. One interesting idea comes from the theoretical findings of Benhabib, Schmitt-Grohé and Uribe (2002). They argue that a central bank could eliminate some of the problems associated with the zero lower bound for nominal interest rates by switching from an interest rate rule to a monetary aggregate rule when nominal interest rates got sufficiently low. ${ }^{36}$ Along these same lines, a monetary authority might use several different types of contingent rules for various policy instruments, which not least of which include targeting exchange market rates possibly

European monetary policy. For a more skeptical view about the marginal usefulness of the monetary aggregates, see Svensson (1999a) and Svensson and Rudebusch (2002).

36 Arguably, the Bank of Japan switch in recent from interest rate targeting to quantitative easing reflects the difficulty of formulating monetary policy in terms of short-term interest rates when the zero lower bound for nominal interest rates is binding. The more recent policy of quantitative easing (ie targeting commercial bank reserves) has parallels to the monetary targeting strategy followed by the United States in the 1930s, but has only recently begun to show some signs of boosting aggregate demand; as of the Summer 2004, deflationary pressures have been waning with some of the upside pressures coming from the transitory influence of relative price changes. Sustained inflation, and expectations that it will persist, have yet to be realized. 
through greater emphasis on exchange rate interventions; this particular option, however, may be more feasible for small economies than for large ones, as discussed above.

Central banks might also find it useful to take actions that more effectively shape private sector expectations, as has been emphasized in the recent literature on the liquidity trap. One possibility is the adoption of a new policy regime with a stronger nominal anchor. As the gold standard period illustrates, a price level anchor appears to have been effective in preventing the zero lower bound for nominal interest rates from being hit. Another means to shape expectations is through words, rather than actions. Central banks that provide a more transparent and credible policy regime are more likely to achieve their goals (Fracasso et al (2003)). Hence, zone 4 would put a premium on central bank credibility and transparency in order to prevent adverse outcomes. This suggests that a central bank interested in entering and maintaining zone 4 would likely want to place particular emphasis on clear, credible communication. Indeed, the stronger the perceived commitment of the monetary authority to maintain the inflation rate in a particular narrow range, or the price level on a particular path, the less likely a pathological expectational channel would be realized. Other possible policies to minimize the macroeconomic risks include well designed fiscal and prudential polices responses.

What we have discussed so far assumes that policy makers fully understand the economic and policy environment. This assumption could be at odds with reality during the transition from a low inflation environment to a low-to-moderate deflation environment. This uncertainty would represent a potential cost policy makers would have to factor into their decision to enter zone 4. The new economic environment could present challenges owing to the possibility that policy makers might need to recalibrate their monetary policy strategies and might find the private sector responding differently than in zone 3. As Lucas (1976) pointed out, when a monetary policy regime changes, the economy might respond quite differently especially if we do not have good theories to model the change.

Finally, a key concern arising from being in zone 4 is the possibility that a modest shock could initiate a sequence of events that could cause the economy to careen uncontrollably into an ugly deflation. While it is impossible to rule out such possibilities in any of the zones, history has shown that deflationary spirals are extreme outcomes that rarely occur in isolation but rather is a product of the confluence of bad economic shocks, bad policies and bad luck. We consider this unlikely outcome in zone 5.

\subsection{Zone 5: deep deflation}

In a situation like the Great Contraction of 1929-1933, many have argued - persuasively in our view - that expansionary monetary policy could have softened the blow to the economy. But, as contractionary forces became sufficiently strong and the monetary transmission mechanism sufficiently impaired, expansionary open market purchases could have driven down short-term interest rates to the zero lower bound without the expected stimulus permeating the economy. Clearly, if such an extreme were to occur, a monetary aggregate targeting strategy would be superior in such a situation. Indeed in the 1930s US experience, short-term interest rates did approach zero by the end of 1932. When the Federal Reserve expanded open market purchases by $\$ 1$ billion in the spring of 1932, it did succeed in temporarily stimulating the economy. This policy was abandoned after several months, some argue, because of concern over the Federal Reserve holdings of free gold (gold reserves in excess of statutory requirements) (Eichengreen (1992)); the evidence, however, is not thoroughly convincing on this point (Bordo, Choudhri and Schwartz (2002)). Others argue that it was abandoned because Congress, which had pressured the Federal Reserve to 
stimulate the economy, went on recess in July 1932 and the Federal Reserve reverted back to its original "liquidationist stance" (Friedman and Schwartz (1963)). ${ }^{37}$ Although the zero lower bound was reached in late 1932, a successful reflationary monetary policy was initiated in March 1933 by the US Treasury actively purchasing gold (and silver) in a deliberate attempt to devalue the dollar. ${ }^{38}$ This evidence supports the cases both for conducting open market operations in assets other than short-term paper and for the use of monetary aggregate targeting in the case of severe deflation.

In the case of the US Great Contraction, although monetary policy did eventually end the "ugly" deflation, the recovery was attenuated by other policies followed by the Roosevelt administration. The NIRA, established to artificially raise wages and prices by restricting the supplies of labor and commodities reduced aggregate supply in 1934-35 below what it would otherwise have been (Weinstein (1981), Bordo, Erceg and Evans (2000), Cole and Ohanian (1999)).

In light of the recent deflation in Japan, it is useful to highlight the financial developments during the Great Contraction. The United States effectively resolved its banking crisis by not allowing forbearance (ie all insolvent banks were closed) and the Banking Holiday of March 1933 in which all of the commercial banks were closed for a week to determine which banks were solvent. At the end of the week one-sixth of the nation's banks were closed. Another policy which aided in resolution was injection of capital into the banking sector by the Reconstruction Finance Corporation (Calomiris and Mason (2004)). Under this view, the moderate deflation in Japan is more symptomatic of deeper supply side problems than the inability of the Bank of Japan to boost aggregate demand via the expansion of the monetary base. Japan's current quantitative easing program, with its huge increase in the money stock, illustrates that inflating the economy via monetary policy alone can only go so far in returning an economy to more normal operating conditions. In particular, monetary policy can certainly boost aggregate demand, as has been clear throughout the historical record and now in Japan, but its impact on supply side developments is rather tenuous and the interaction of the supply side and the monetary transmission mechanism can get seriously distorted in a way that can complicate the calibration of the monetary policy response.

Finally, but not least, it is important to note that, despite the extremes of conditions, it is not clear that a liquidity trap was truly realized in the Great Contraction. If it had, the monetary aggregates, as well as other instruments of monetary policy, would have been impotent. In such a situation, the monetary authority would have had few concrete options but to wait for fiscal and prudential policies to return the economy to a greater sense of normalcy. A set of intriguing alternative proposals for escaping liquidity traps has been advocated in recent years. Svensson (2003b), Krugman (1998), Eggertsson (2004) and Eggertsson and Woodford

37 Most Federal Reserve officials believed in the "real bills doctrine" which in simplest terms argued that the central bank should only accommodate member bank lending based on self-liquidating real bills issued to finance commercial activity. They should not accommodate bills financing speculative activity. In this view the Great Contraction was said to have resulted from "over-speculation" and it was further believed that open market purchases would only rekindle further speculative lending.

38 Bordo et al (2002) demonstrate that had the Federal Reserve followed a stable money policy throughout the Great Contraction, by offsetting the shocks to money demand and supply that occurred, a severe recession could have been avoided. In a similar vein, Christiano et al (2004) conduct a counterfactual exercise in which expansionary monetary policy actions are taken after the shocks are revealed. They are able to avoid the zero lower bound constraint and offset the Great Contraction. Bordo et al (2002) provide simulations which demonstrate that had such policies been followed the Federal Reserve would not have been constrained by its gold reserves. 
(2003) have argued that central banks could manipulate private sector expectations about future price levels, which in turn would boost inflation expectations once the policy was adopted. Svensson $(2001,2003 b)$ offers what he calls the "foolproof" way of escaping a liquidity trap by simultaneously announcing a depreciation of the exchange rate and elevated price level target. Once the price level target was realized, the monetary authority would then initiate a preannounced exit strategy of a floating rate regime with an inflation (or price level) targeting regime. While sensible in theory, the ability of the monetary authority to precisely and credibly manipulate private sector expectations in a well orchestrated manner is still an open question. ${ }^{39}$ Unfortunately, with little evidence of liquidity traps in the historical record, it is difficult to know the likely success or the risks of unintended side effects. ${ }^{40}$

\subsection{The zonal approach: summary}

In sum, monetary policy can eliminate deflation of any magnitude just as it can eliminate inflation. However, the appropriate monetary policy strategy depends on the inflation/deflation zone that a central bank finds itself in. Emphasizing the monetary aggregates appears, from a historical perspective, to be rather important during periods of high inflation and deep deflation. During periods of low inflation, velocity over short periods of time has shown a tendency to be more volatile and unpredictable than variation in the natural interest rate, thereby tilting the balance of the arguments toward the reliance on interest rate instruments in the conduct of monetary policy. However, in the zone of low inflation/price stability and low-to-moderate deflation, the influence of the zero lower bound for short-term nominal interest rates makes reliance on short-term interest rates more problematic; hence, the balance tilts toward the monetary aggregates playing a dominant role as the policy instrument and guide of choice. Finally, even though monetary policy has the ability to generate inflation, it cannot necessarily eliminate stagnation arising from deepseated structural problems, especially a dysfunctional financial intermediation system.

\section{CONCLUSIONS}

This broad-brush historical approach has yielded important insights about deflation and monetary policy both in the past as well as in the present. One striking feature of the historical record is that deflation was a common phenomenon in the pre-World War II period owing in large part to the low inflation environment and the monetary regime that naturally led to waves of inflation and deflation. In many ways, the current policy environment better resembles that of the distant past than of the period from 1970-1995. This not only suggests that looking to the past may help resolve some current policy issues but also that policy models might benefit from being calibrated to those developments in the distant past.

To an observer looking at the long history, current concerns about deflation may seem to be somewhat overblown. It is abundantly clear that deflation need not be associated with

39 Kugler and Rich (2002) have raised some doubts about whether foolproof way would have worked well in the case of Switzerland in the 1970s.

40 A theoretically sound proposal based on monetary theory has also been proposed to help avoid liquidity traps. Goodfriend (2000) and Buiter and Panigirtzoglou (2002) discuss the possibility of the Gesell tax on money as an alternative means to increase the room for manoeuvre with interest rate instruments when a liquidity trap would have otherwise formed. While theoretically interesting, its practical relevance in the current policy environment seems remote. 
recessions, depressions, crises and other unpleasant conditions. The historical record is replete with good deflations. There are, of course, plenty of bad deflations too. But, it is unclear to us that the bad deflations within the context of stable nominal anchor (ie price stability) regimes were any worse than a similarly-sized disinflation in an inflationary environment. The empirical tests, both on the past and on more recent data, suggest that the asymmetries were not particularly daunting and might be regime-dependent. The recent experience with nominal wage changes also provides some insights into the possibility that as inflation rates remain very low, real rather than nominal compensation changes will play the key role in decision making, as theory would suggest. To be sure, some historical episodes of deflation were, in our typology, labeled as "ugly". But the historical record makes it clear that most of those were isolated to the Great Depression period. While a return of such conditions cannot be completely ruled out for any particular economy, it is also true that once one digs into the reasons for deflation in the Great Depression it becomes quite clear that the possibility of its reappearance is hard to even imagine. Moreover, recent research has found that even during these extreme conditions there is little evidence that liquidity traps developed, thereby putting the recent theoretical literature on liquidity traps, and the need for unconventional monetary policy measures, in quite a different light.

The perceived costs of deflation are also important. The possible asymmetric nature of the costs associated with deflation has been used to justify asymmetric monetary policy approaches to deviations of inflation around a central bank's target rate, ie a more aggressive reaction to a deflation scare than to upside risks to inflation of the same size. If the costs are real and asymmetric, such policy reactions might be optimal, but they will nonetheless imply a tendency toward an upward bias to inflation; this policy approach would also tend to be procyclical. Indeed, if the costs of deflation were not asymmetric, such a policy could generate periodic overshooting of the inflation target - particularly during recovery periods.

The gold standard period provides another vantage point with which to compare current regimes to those in the past: the credible nominal anchor. The success in the past decade or so in lowering the average inflation rate underscores the importance of adopting sound and credible monetary policy regimes. A key question going forward is whether the current regimes are really offering the best nominal anchors. In some respects, the current regimes can be improved by adopting an explicit price level target or flexible price targeting versus an inflation targeting regime. Other considerations would, of course, have to be considered before embracing such a regime, but at least with respect to the nominal anchor dimension, the price level approach has both theoretical and historical support. Moreover, as pointed out in our zonal approach to monetary policy, the importance of a strong and credible nominal anchor is very important in low inflation and low-to-moderate deflation zones. One additional issue with respect to credibility is the importance for a central bank to operate in an environment of sound fiscal and prudential frameworks. Having these policies in order will not only reduce the likelihood of a bad or ugly deflation but will also help to strengthen the monetary policy transmission mechanism in the case of an unwelcome, but transitory, deflation.

Our zonal approach to monetary policy highlights several key tradeoffs for monetary policy makers. First, what zone is the best for a particular central bank? Most central banks have shown, by revealed preference, that zone 3 is a generally preferred zone. Theory suggests that zone 4, the moderate deflation zone, might be even better. And, arguably some central banks have been operating in this zone, especially if a biased-adjusted measure of inflation were used. The evidence so far suggests that deflation can be a regular part of a policy environment without excessive fear of the imminent disaster. To be sure, such an environment may involve some transitional costs as agents and policy makers become used to the environment. And, 
without doubt, some transitions might be bumpy at times. But such behavior should not be extrapolated to suggest that the steady state will be vulnerable to the same type of turbulence.

Second, the choice of the low inflation and low-to-moderate deflation zones would generally dictate the adoption of a mixed strategy towards the conduct of monetary policy. At the very least, the pathological problems with short-term interest rate instruments demand more attention. This emphasis is somewhat at odds with the conventional wisdom. While there are various options that central banks can choose from, the historical record clearly points to greater reliance on the monetary aggregates, if only for cross-checking purposes. If velocity changes were better understood, the role of the monetary aggregates might play a more central role. This, of course, is ultimately an empirical issue.

Third, in the end the tradeoffs for monetary policy appear to be fairly stark. On the one hand, central banks operating in (the lower end of) zone 3 face the fact that they will always be one recession or strong supply shock away from deflation. This means that interest rate rules will routinely become less useful as guides for monetary policy. In our view, this suggests that the study of the role of money in the conduct of monetary policy needs to be reinvigorated at central banks with the goal of designing a mixed policy strategy that relies on the both interest rate rules and monetary aggregate targeting. Of course, the relative weights on these strategies in practice will depend on the inflation/deflation zone as well as the stability of velocity for the monetary aggregates. On the other hand, central banks can choose to avoid most of these potential costs by setting their sights on a higher steady-state inflation rate; this would naturally yield a lower incidence of deflation but at the cost of a steady stream of losses for the foreseeable future associated with the higher inflation. 


\section{TECHNICAL APPENDIX}

The historical supply and demand shocks are estimated using a standard variant of the Blanchard-Quah VAR-based methods of time series analysis. Following Keating and Nye (1998), we estimate a VAR model of output growth and inflation while imposing moving average coefficient restrictions to identify temporary and permanent shocks to output, which are interpreted as demand and supply shocks, respectively. In particular, the model is

$$
\begin{aligned}
& y_{t}=\alpha_{y} d(t)+\theta_{11}(L) \gamma_{t}+\theta_{12}(L) e_{t} \\
& \pi_{t}=\alpha_{\pi} d(t)+\theta_{21}(L) \gamma_{t}+\theta_{22}(L) e_{t}
\end{aligned}
$$

where $y$ and $\pi$ are output growth and inflation, $d(t)$ is a vector of an intercept and time trend, and $(\gamma, \varepsilon)$ are the permanent and temporary shocks. The estimation procedure imposes the constraint that $\theta_{12}(1)=0$.

The $P^{*}$ model has a long history in the annals of monetary economics, going back as far as David Hume (Humphrey (1989)). The model is derived from the equation of exchange, $M V=$ $P Y$, where $M$ is the money aggregate, $V$ is velocity for that aggregate, $P$ is the price level and $Y$ is real output. $\left(P-P^{*}\right) / P^{*}$ is defined to be

$$
\left(P-P^{*}\right) / P^{*}=\left(P-\frac{M V^{*}}{Y^{*}}\right) / P^{*},
$$

where $V^{*}$ is a 10 -year moving average of actual velocity and $Y^{*}$ is the recursively estimated Hodrick-Prescott measure of output.

In this model, the price level is assumed to adjust sluggishly so that it is always catching up to the changes in the money supply (adjusted for long-run variation in velocity and output). When $\left(P-P^{*}\right) / P^{*}>0$, the price level experiences downward pressure, all else the same; when $\left(P-P^{*}\right) / P^{*}<0$, the price level experiences upward pressure. The bigger is the $P-P^{*}$ gap, the greater the likelihood of a big adjustment.

The ordered probit model of deflation exploits the historical observation that deflations appear to have fallen into three different types: the good, the bad and the ugly. Using a standard latent variable formulation of the problem, assume that a latent variable $\lambda^{*}$ can be described in terms of an observation vector $X$ in the following way as

$$
\lambda^{*}=X \beta+e
$$

where $\beta$ is a fixed but unknown coefficient and $e$ is a normally-distributed random variable with a zero mean and fixed variance, $N(0,1)$. The relationship between the observed deflation type indicator and the latent variable is

$$
\left\{\begin{array}{l}
\Lambda_{i}=0(\text { good deflation }), \text { if } \lambda^{*} \leq \alpha_{1} \\
\Lambda_{i}=1(\text { bad deflation }), \text { if } \alpha_{1}<\lambda^{*} \leq \alpha_{2} \\
\Lambda_{i}=2(\text { ugly deflation }), \text { if } \alpha_{2} \leq \lambda^{*}
\end{array}\right.
$$

where the $\alpha_{1}$ and $\alpha_{2}$ are unobserved threshold parameters that must be estimated. Therefore the conditional distribution of $\Lambda_{i}$ on $\mathrm{X}$ can be written as

$$
\begin{gathered}
P\left(\Lambda_{i}=0 \mid X\right)=P\left(\lambda^{*} \leq \alpha_{1} \mid X\right)=P\left(X \beta+e \leq \alpha_{1} \mid X\right)=\Phi\left(\alpha_{1}-X \beta\right) \\
P\left(\Lambda_{i}=1 \mid X\right)=P\left(\alpha_{1}<\lambda^{*} \leq \alpha_{2} \mid X\right)=\Phi\left(\alpha_{2}-X \beta\right)-\Phi\left(\alpha_{1}-X \beta\right)
\end{gathered}
$$




$$
P\left(\Lambda_{i}=2 \mid X\right)=P\left(\alpha_{2}<\lambda^{*} \mid X\right)=1-\Phi\left(\alpha_{2}-X \beta\right) .
$$

The coefficient $\beta$ and the threshold parameters are estimated using maximum likelihood methods. Two standard statistical measures of fit are provided in the table - the pseudo$R^{2}$ and the percent correctly predicted metric (Green (2000)). While it is generally difficult to draw inferences about how the probability of a particular type from the signs of the coefficient estimates, the marginal effects of the effects can be measured for qualitative variables, like the banking crises variable. Those results are also reported in Table 7. 


\section{BOX 1. RECENT DEFLATION EXPERIENCES}

History has shown that in a low inflation environment the incidence of deflation can be quite high, and recent experience is no exception to this tendency. To put the historical lessons for today in a somewhat brighter light we briefly review recent policy challenges arising from deflation. The most notable case is that of Japan. We also consider Hong Kong (China, hereafter referred to as Hong Kong), China, Singapore, Taiwan (China, hereafter referred to as Taiwan), as well as recent "deflation scares" in the United States and Europe.

Japan The example of deflation receiving the most attention today is Japan which has had bouts of falling prices since the mid-1990s. It seems to be a case of "bad" deflation characterized by stagnant real activity along with mild deflation (Ahearne et al (2002)). Arguably, the underlying cause of the Japanese problem was not deflation, per se, but the problems in the banking system with its concomitant adverse consequences for the monetary transmission mechanism (Hetzel (2004), Sellon (2004), Baba et al (2004)). ${ }^{41}$ The continued weakness of the Japanese banking system, ie the inability to close or recapitalize insolvent banks, may have hampered the Bank of Japan's ability to stimulate bank lending. To put it another way, it does not seem reasonable in retrospect that a somewhat lower real interest rate of a couple of percentage points would have significantly improved conditions, as experience with the zero interest rate policy and quantitative easing policy has revealed.

Recent data from Japan has once again raised hopes that its economy is truly on the mend. Greater momentum in economic activity and tentative signs of progress in dealing with its structural financial issues have been promising. The extent to which the quantitative easing policy has helped to achieve this outcome will surely be of considerable debate for years to come. But, we see this correlation as suggestive evidence that it is still true that aggressive expansion of the monetary base sufficient to boost broader money aggregates can work to revive aggregate demand. It should be noted, however, that the very accommodative monetary policy has not been without its risks, especially since policy has had to deal with the consequences of an intrinsically non-monetary problem. One potential problem for the Bank going forward has been rapid rise in the size of the Bank of Japan's balance sheet. It is now the largest in its history, growing to $¥ 140$ trillion in early 2004 , or roughly $25 \%$ of nominal GDP. ${ }^{42}$ This means that when the economy returns back to a more normal situation and velocity returns to something closer to its historical average, the Bank will have to reduce this monetary overhang by draining a considerable amount of liquidity from the economy. During the transition, the Bank of Japan may face a delicate balancing act: if it were to withdraw the liquidity too quickly, it risks stalling the recovery; if it withdraws the liquidity too slowly, there would be the risk of an excessively strong burst of economic activity and a concomitant surge in inflation, at least in the short run, requiring a significant tightening of monetary policy that could engender considerable volatility.

Hong Kong The deflation experience in Hong Kong reinforces our view that the distant past has important implications for the present. The source of the problem has not been a banking

41 Hayashi and Prescott (2002) see low productivity growth as the underlying problem. Fukao et al (2003) argue, however, that they overestimated the size of the productivity decline because of biases in aggregate data.

42 By means of comparison, the ECB, the Federal Reserve and the Bank of England have balances sheets that are roughly $12 \%, 7 \%$ and $5 \%$ of nominal GDP, respectively. 
problem as in Japan. For example, the banking sector, while feeling the pressures from the unfolding events, does not appear to have suffered from debt deflation (Gerlach and Peng (2002)). Rather, the persistent deflation in Hong Kong appears to reflect the consequences of a sharp property price decline, in the context of a currency board arrangement. The desire to peg to the US dollar meant that the huge wealth shock from the collapse of housing prices would have to be accommodated through the reduction of domestic wages and prices rather than through the exchange rate. And, as was seen in the post-World War I period, those countries that tried to force a large adjustment on domestic prices and wages, rather than adjusting the gold parity, faced greater and more drawn out economic adjustment costs. In an analogous way, the choice to stick to its nominal anchor in the form of a currency board instead of devaluing required considerable labor and product market adjustments.

The experience illustrates several important points. First, asset price booms and busts may be a much more important source of persistent deflation than conventional supply and demand shocks. Second, evidence on nominal wage flexibility, while hardly perfectly flexible, shows evidence that as deflation became more entrenched, labor became more concerned with real rather than nominal changes. The sharp deceleration in nominal wage growth in the aftermath of the Asian crisis illustrated some downward flexibility. Nominal wage growth fell to around zero percent during 1998, which led to a rise in real wages as deflation took hold. However, since then, nominal wage and real wage growth has declined (Fan (2003)). Third, the HKMA could have reflated the economy more quickly but it would have come at the cost of abandoning their currency board. Some might see some merit to abandoning it, but clearly, in a fiat currency world, credible and adhered-to commitments may far outweigh the transitory cyclical gains associated with abandonment. The Hong Kong situation illustrates that the cost of reflating the economy might have been higher in terms of reputation and commitment than the cost of maintaining a persistent deflation.

China China has recently been facing an acceleration in consumer prices, but in the past several prior years, it had experienced modest but persistent deflation. Strong economic growth accompanying its export-driven development strategy generated huge productivity gains that held price pressures in check. In addition, the access to a very elastic supply of low cost labor has helped to cap wage pressures, as has the excess capacity of state-owned enterprises which often have operated at losses. In a historical perspective, the deflation appeared to be of the good type. As recent price developments highlight, the monetary policy transmission mechanism, despite some unique features of the Chinese economy, broadly operates as in other countries. Rapid growth in the monetary aggregates eventually translates into inflation. This also suggests that the traditional monetarist prescription for deflation is an important option for central banks in emerging market economies. Looking forward, however, a return to deflation, possibly of the bad type, cannot be ruled out. The vulnerabilities in their banking system represent a considerable source of uncertainty (Fung and Ma (2002)). Of course, as in the gold standard period or in Hong Kong recently, China's choice of a pegged exchange rate could complicate the adjustment process, especially since many believe that the notional value may be out of line with fundamentals.

Singapore and Taiwan Singapore and Taiwan have also experienced very low inflation rates that in certain years dipped below zero. In general, the deflation rates were rather mild and transitory, and largely corresponded to unexpected slowdowns in economic activity (BIS (2003)). More important, they did not present particularly daunting policy challenges but rather were examples of low inflation economies experiencing the typical procyclical tendencies of inflation during the business cycle.

Deflation scares in the United States and Europe The United States has not experienced deflation in recent years. But it did get uncomfortably close for the Federal Reserve. In 2003, 
as core CPI inflation continued to fall with only tentative signs of recovery, there was a risk that deflation would materialize. Arguably, if one were to take into account the statistical bias in price indexes, the United States was in the deflation zone for a short period of time. Part of the concern about a more persistent deflation environment came from the assessment that the recovery was still fragile and that strong productivity gains were keeping slack ample. In the end, strong stimulus from monetary and fiscal policy helped support economic growth as the private sector gained momentum. By mid-2004, the risks to deflation appeared to have largely vanished and were replaced by increasing concern about the upside risks to inflation. In some sense, the United States experienced a "good" deflation scare, ie one where the deflation risk arose from better-than-anticipated productivity gains. There is some question about how aggressively monetary policy should respond to good scares. If a central bank were to get behind the inflation curve, the easier monetary policy could translate into a rise in inflation above its desired rate before the effects of a subsequently tight policy permeated the economy.

In contrast, the deflation scares in Germany and Austria are probably best thought of as "bad" scares, even though the risks of deflation in the euro area as a whole have been very low (Issing (2002), Svensson (2003a)). In these countries, deficient demand was mostly responsible for the concerns about falling prices. Easy monetary policy with some fiscal expansion (but more limited than in the United States because of the constraints, at least soft ones, imposed by the Stability and Growth Pact) has helped to prevent deflation from materializing as well as the recovery in external demand. In contrast to the US scare, the monetary policy response to a "regional" scare in the euro area has been constrained owing to the fact that euro-wide inflation has been near the upper end of the ECB's preferred range for the inflation rate. The optimality of the policy tradeoff is likely to involve the costs of higher inflation for all versus the cost of deflation for the few.

Switzerland's recent experience illustrates the case where slow productivity growth (possibly causing the Wicksellian natural rate to decline) and cyclical weakness has led policy rates to close in on the zero lower bound for short-term interest rates. As the Swiss National Bank has emphasized, this development has not made monetary policy ineffective, but rather requires greater emphasis on quantitative measures and other alternative policy instruments. Switzerland, being a small open economy, also has had the option, via central bank intervention in foreign exchange markets, to depreciate the Swiss Franc as a means to help ward off unwelcome deflation. ${ }^{43}$

Sweden offers the latest glimpse into an economy having recently faced a modest deflation scare of the "good" variety. Price changes were unexpectedly low in 2003 and early 2004 arising from several factors, such as low import prices, the unwinding of past relative price increases and, potentially most important, weaker than expected unit labor costs. The unit labor cost developments reflect both faster productivity, which has been helping to support the recovery, and subdued wage trends. The scare, while short in duration, highlighted the risks of a temporary bout of price declines in a low inflation economy, and it highlights some features of the historical experience of deflation: deflation can be unexpected, associated with

43 See Kugler and Rich (2002) for a discussion of the Swiss National Bank's conduct of monetary policy in the late 1970s low interest rate environment in Switzerland. In that situation, the Swiss National Bank pegged its exchange rate to forestall the deflationary pressures coming from the "excessive upvaluation of the Swiss Franc". While defusing the exchange rate and deflation problems, they could not prevent an eventual increase in inflation. See Zurlinden (2003) for a discussion of Switzerland's deflation experience in the Great Depression. 
robust economic growth and be a regular part of a low inflation economy, especially for small economies.

\section{REFERENCES}

Ahearne, A, J Gagnon, J Haltimaier and S Kamin et al (2002): "Preventing deflation: lessons from Japan's experience in the 1990s", Federal Reserve Board International Finance Discussion Papers, no 729, June.

Akerlof, G, W Dickens and G Perry (1996): "The macroeconomics of low inflation", Brookings Papers on Economic Activity, vol 1, pp 1-59.

(2000): "Near-rational wage and price setting and the long-run Phillips curve", Brookings Papers on Economic Activity, vol 1, pp 1-60.

Altonji, J and P Devereux (1999): "The extent and consequences of downward nominal wage rigidity", NBER Working Paper, no 7236, July.

Andrés, J, J Lopez-Salido and E Nelson (2004): “Tobin's imperfect asset substitution in optimizing general equilibrium", Federal Reserve Bank of St. Louis Working Paper 2004$003 A$, February.

Atkeson, A and P Kehoe (2004): "Deflation and depression: is there an empirical link?", American Economic Review, May, pp 99-103

Baba, N, S Nishioka, N Oda, M Shirakawa, K Ueda and H Ugai (2004): “Japan's deflation, problems in the financial system and monetary policy", $3^{\text {rd }}$ Annual BIS Conference on "Understanding low inflation and deflation", Brunnen, Switzerland, 18-19 June.

Balke, N and R Gordon (1986): "Historical data", in R Gordon (ed), The American business cycle: continuity and change, University of Chicago Press.

Ball, L (1994): “What determines the sacrifice ratio?”, in N G Mankiw (ed), Monetary policy, University of Chicago Press, pp 155-82.

Bank for International Settlements (2003): "Deflation risk and its implications", in Chapter IV of the 73rd Annual Report, June, pp 69-79.

Benhabib, J, S Schmitt-Grohé, and M Uribe (2002): “Avoiding liquidity traps", Journal of Political Economy, no 3, pp 535-563.

Berg, C and L Jonung (1999): "Pioneering price level targeting: the Swedish experience 1931-37”, Journal of Monetary Economics, June, pp 525-51.

Bernanke, B (1983): "Nonmonetary effects of the financial crisis in the propagation of the Great Depression", American Economic Review, June, pp 257-76.

(1995): "The macroeconomics of the Great Depression: a comparative approach", Journal of Money, Credit, and Banking, February, pp 1-28.

(2002): "Deflation: making sure 'it' doesn't happen here", remarks before the National Economists' Club, Washington, November.

Bernanke, B and K Carey (1996): "Nominal wage stickiness and aggregate supply in the Great Depression", Quarterly Journal of Economics, August, pp 853-83. 
Bernanke, B and H James (1991): "The gold standard, deflation, and financial crisis in the Great Depression: an international comparison", in R G Hubbard (ed), Financial markets and financial crises, University of Chicago Press, pp 33-68.

Bernanke, B and V Reinhart (2004): "Conducting monetary policy at very low short-term interest rates", presented at the Meeting of the American Economic Association, San Diego, January.

Bewley, T (1995): “A depressed labour market as explained by participants", American Economic Review, pp 250-4.

Blanchard, O and D Quah (1989): “The dynamic effects of aggregate demand and supply disturbances", American Economic Review, September, pp 655-73.

Blinder, A, E Canetti, D Lebow and J Rudd (1998): Asking about prices: a new approach to understanding price stickiness, Russell Sage Foundation.

Bloomfield, A (1959): Monetary policy under the international gold standard, 1880-1914, Federal Reserve Bank of New York.

Bomfim, A and G Rudebusch (1998): "Opportunistic and deliberate disinflation under imperfect credibility", Board of Governors of the Federal Reserve System FEDS Discussion Paper, no 1998-1, January.

Bordo, M (1984): "The gold standard: the traditional approach", in M Bordo and A Schwartz (eds), A retrospective on the classical gold standard, 1821-1931, University of Chicago Press, pp 23-113.

(1986): "Financial crises, banking crises, stock market crashes and the money supply: some international evidence, 1870-1933", in F Capie and G Wood (eds), Financial crises and the world banking system, Macmillan, pp 190-248.

(1999): The gold standard and related regimes: collected essays, Cambridge University Press.

(2003): "Comments on 'The Great Depression as a credit boom gone wrong", presentation at the $2^{\text {nd }}$ BIS Conference on "Monetary stability, financial stability and the business cycle", March.

Bordo, M, E Choudhri and A Schwartz (1995): "Could stable money have averted the Great Contraction?", Economic Inquiry, July, pp 484-505.

(2002): "Was expansionary monetary policy feasible during the Great Contraction: an examination of the gold standard constant", Explorations in Economic History, January, pp 128.

Bordo, M, R Dittmar and W Gavin (2003): "Gold, fiat money and price stability", Federal Reserve Bank of St. Louis Working Papers, no 2003-014, November.

Bordo, M, M Dueker and D Wheelock (2002): “Aggregate price shocks and financial stability: a historical analysis", Economic Inquiry, October, pp 521-38.

(2003): "Aggregate price shocks and financial stability: the United Kingdom 17961999”, Explorations in Economic History, April, pp143-69

Bordo, M and B Eichengreen (1999): "Is our current international economic environment unusually crisis prone", prepared for the Reserve Bank of Australia conference on private capital, August, pp 18-74. 
Bordo, M, B Eichengreen and D Irwin (1999): "Is globalisation today really different from globalisation a hundred years ago?", Brookings Trade Forum, the Brookings Institution, pp 150 .

Bordo, M, B Eichengreen, D Klingebiel and M Martinez-Peria (2001): "Is the crisis problem growing more severe?", Economic Policy, April, pp 53-82.

Bordo, M and R Ellson (1985): "A model of the classical gold standard with depletion", Journal of Monetary Economics, July, pp 109-20.

Bordo, M, C Erceg and C Evans (2000): "Money, sticky wages and the Great Depression", American Economic Review, December, pp 1447-63.

Bordo, M and J Haubrich (2004): "The yield curve, recessions and the credibility of the monetary regime: long-run evidence 1875-1997”, NBER Working Paper, no 10431, June.

Bordo, M, J Landon-Lane and A Redish (2004): "Good versus bad deflation: lessons from the gold standard era", NBER Working Paper, no 10329, February.

Bordo, M and R MacDonald (2004): "Interest rate interactions in the classical gold standard: 1880-1914: was there monetary independence?", Journal of Monetary Economics, forthcoming.

Bordo, M and A Murshid (2003): "Globalization and changing patterns in the international transmission of shocks in financial markets", in W Hunter, G Kaufman and M Pomerleano (eds), Asset price bubbles: the implications for monetary, regulatory, and international policies, Cambridge, The MIT Press.

Bordo, M and A Redish (2004): "Is deflation depressing: evidence from the classical gold standard", in R Burdekin and P Siklos (eds), Deflation: Current and Historical Perspectives, Cambridge University Press, forthcoming.

Bordo, M and A Schwartz (1999): "Under what circumstances, past and present, have international rescues of countries in financial distress been successful?", Journal of International Money and Finance, August, pp 683-708.

Bordo, M and E White (1984): "A tale of two currencies: British and French finance during the Napoleonic Wars", Journal of Economic History, no 2, June, pp 303-316.

Borio, C, W English and A Filardo (2003): "A tale of two perspectives: old or new challenges for monetary policy", BIS Working Papers, no 127, Basel, February.

Borio, C and A Filardo (2004): "Back to the future? Assessing the deflation record", BIS Working Papers, no 152, March.

Borio, C and P Lowe (2002a): "Asset prices, financial and monetary stability: exploring the nexus", paper presented at the BIS Conference on "Changes in risk through time: measurement and policy options", BIS Working Papers, no 114, July.

(2002b): “Assessing the risk of banking crises", BIS Quarterly Review, December, pp 43-54.

Borio, C and P Lowe (2004): "Securing sustainable price stability: should credit come back from the wilderness", unpublished BIS working paper, February.

Buiter, W and N Panigirtzoglou (2002): "Overcoming the zero bound on nominal interest rates with negative interest on currency: Gesell's solution”, EBRD Working Paper, unpublished, October. 
Burdekin, R and P Siklos (1999): "Exchange rate regimes and shifts in inflation persistence: does nothing else matter?", Journal of Money, Credit and Banking, May, pp 235-47.

- (2004): "Fears of deflation and policy responses then and now", in R Burdekin and P Siklos (eds), Deflation, Cambridge University Press.

Cagan, P (1979): Persistent inflation, Colombia University Press.

(1984): "War, prices and interest rates: a martial solution to Gibson's paradox: comment", in M Bordo and A Schwartz (eds), A retrospective on the classical gold standard, 1821-1931, University of Chicago Press, pp 604-10.

Calomiris, C and J Mason (2004): "How to restructure failed banking systems: lessons from the US in the 1930s and Japan in the 1990s", in T Ito and A Krueger (eds), Privatization, corporate governance and transition economies in East Asia, University of Chicago Press.

Cecchetti, S (1992): "Prices during the Great Depression: was the deflation of 1930-1932 really unanticipated?", American Economic Review, March, pp 141-56.

Chari, V (2004): "Optimal monetary policy: theory and lessons", presentation at the Federal Reserve Bank of Minneapolis, November.

Chari, V, L Christiano and P Kehoe (1991): "Optimal fiscal and monetary policy: some recent results", Journal of Money, Credit, and Banking, August, pp 519-39.

Choudhri, E and L Kochin (1980): "The exchange rate and the international transmission of business cycle disturbances: some evidence from the Great Depression”, Journal of Money, Credit, and Banking, November, pp 565-74.

Christiano, L, R Motto and M Rostagno (2004): "The Great Depression and the Friedman and Schwartz hypothesis", unpublished ECB working paper.

Coenen, G, A Orphanides and V Wieland (2004): "Price stability and monetary policy effectiveness when nominal interest rates are bounded at zero", Advances in Macroeconomics, First Quarter, pp 1-23.

Cogley, T and T Sargent (2001): "Evolving post-World War II US inflation dynamics", NBER Macroeconomic Annual, MIT Press, pp 331-79.

Cole, H and L Ohanian (1999): "The Great Depression in the United States from a neoclassical perspective", Federal Reserve Bank of Minneapolis Quarterly Review, Winter, pp 2-24.

Crafts, N (2000): "Historical perspectives on the information technology revolution", Background paper for the summer 2001 World Economic Outlook, June.

Davis, J (2002): "An annual index of US industrial production, 1790-1915", unpublished working paper.

Delong, B (1999): "Should we fear deflation?" Brookings Papers on Economic Activity, issue 1, pp 225-41.

(2000): “America's historical experience with low inflation", Journal of Money, Credit and Banking, November, part 2, pp 979-93.

Dutton, J (1984): "The Bank of England and the rules of the game un the international gold standard", in A retrospective on the classical gold standard, 1821-1931, University of Chicago Press, pp 173-95. 
Eggertsson, G (2004): "The deflation bias and committing to being irresponsible", unpublished IMF working paper, March.

Eggertsson, G and M Woodford (2003): "The zero bound in interest rates and optimal monetary policy," Brookings Papers on Economic Activity, no 1, pp 139-233.

Eichengreen, B (1992): Golden fetters: the gold standard and the Great Depression, Oxford University Press.

Eichengreen, B and J Sachs (1985): "Exchange rates and economic recovery in the 1930s", Journal of Economic History, December, pp 925-46.

Enders, W and Granger C (1998): "Unit root tests and asymmetric adjustment with an example using the term structure of interest rates", Journal of Business and Economic Statistics, July, pp 304-11.

English, W (2000): “Comment on: America's historical experience with low inflation", Journal of Money, Credit and Banking, November, 998-1006.

Fisher, I (1933): "The debt-deflation theory of great depressions", Econometrica, October, pp 337-57.

Fregert, K and L Jonung (2001): "The formation, perceptions and effects of economic policy in the deflations of 1921-23 and 1931-33 in Sweden", unpublished manuscript, April.

Friedman, M (1968): “Inflation: causes and consequences", in Dollars and Deficits, PrenticeHall.

(1969): The optimum quantity of money and other essays, Aldine.

Friedman, M and A Schwartz (1963): A Monetary History of the United States 1867-1960, Princeton University Press.

(1982): Monetary trends in the United States and the United Kingdom, University of Chicago Press.

Fujiki, H, K Okina and S Shiratsuka (2001): "Monetary policy under zero interest rate: viewpoints of central bank economists", Monetary and Economic Studies, February, pp 89130.

Fukao, K, T Inui, H Kawai and T Miyagawa (2003): "Sectoral productivity and economic growth in Japan, 1970-98: an empirical analysis based on the JIP database", unpublished working paper, July.

Fung, B, Ma, G, and McCauley, R (2003): "Deflation and its challenges to monetary policy in Asia", Unpublished BIS working paper.

Gagnon, J (1997): "Inflation regimes and inflation expectations", Board of Governors of the Federal Reserve System International Finance Discussion Papers, no 581, May.

Galí, J, S Gerlach, J Rotemberg, H Uhlig and M Woodford (2004): Monitoring the European Central Bank, CEPR.

Gerlach, S and W Peng (2002): "Bank lending and property prices in Hong Kong", Hong Kong Monetary Authority Quarterly Bulletin, August.

Gerlach, S and L Svensson (2003): "Money and inflation in the euro area: a case for monetary indicators?", Journal of Monetary Economics, pp 1649-72.

Goodfriend, M (1993): "Interest rate policy and the inflation scare problem: 1979-1992, Federal Reserve Bank of Richmond Economic Quarterly, Winter, pp 1-24. 
(2000): "Overcoming the zero bound on interest rate policy", Journal of Money, Credit and Banking, November, part 2, pp 1007-35.

Green, W (2000): Econometric analysis, Prentice Hall.

Hanes, C (1993): "The development of nominal wage rigidity in the late $19^{\text {th }}$ century", American Economic Review, September, pp 732-56.

(2004): "The Liquidity Trap and U.S. Interest Rates in the 1930s", Journal of Money, Credit and Banking, forthcoming.

Hanes, C and J James (2001): Wage adjustments under low inflation: evidence from US history, unpublished University of Mississippi manuscript, April.

Haug, A and W Dewald (2004): "Longer-term effects of monetary growth on real and nominal variables, major industrial countries, 1880-2001", European Central Bank Working Paper Series, no 382, August.

Hayashi, F and E Prescott (2002): "The 1990s in Japan: a lost decade", Review of Economic Dynamics, January, pp 206-35.

Hetzel, R (2004): "Price stability and Japanese monetary policy", Federal Reserve Bank of Richmond unpublished working paper, February.

Hsieh, C-T and C Romer (2001): "Was the Federal Reserve fettered? Devaluation expectations in the 1932 monetary expansion", NBER Working Paper, no 8113, February.

Humphrey, T (1989): "Precursors of the p-star model”, Federal Reserve Bank of Richmond Economic Review, July/August, pp 3-9.

(2003): "Classical deflation theory", Federal Reserve Bank of Richmond Working Paper, no 03-13, November.

International Monetary Fund (IMF) (2003): "Deflation: determinants, risks and policy options - findings of an interdepartmental task force", International Monetary Fund, April.

Issing, O (2001): "Monetary policy in a changing economic environment", in Rethinking stabilization policy, symposium sponsored by the Federal Reserve Bank of Kansas City, Jackson Hole, Wyoming, 29-31 August, pp 183-205.

(2002): "The euro after four years: is there a risk of deflation?", speech at the $16^{\text {th }}$ European Finance Convention, December.

Issing, O, V Gaspar, I Angeloni and O Tristani (2001): Monetary policy in the euro area: strategy and decision-making at the European Central Bank, ECB.

Keating, J and J Nye (1998): "Permanent and transitory shocks in real output: estimates from nineteenth-century and postwar economies", Journal of Money, Credit and Banking, May, pp 231-51.

Keynes, J (1936): The general theory of employment interest and money, Macmillan Press Ltd.

Kimura, T and K Ueda (2001): "Downward nominal wage rigidity in Japan", Journal of Japanese and International Economies, pp 50-67.

King, M (1999): "Challenges for monetary policy: new and old", in New challenges for monetary policy, symposium sponsored by the Federal Reserve Bank of Kansas City, Jackson Hole, Wyoming, 26-28 August, pp 11-58. 
Klein, B (1975): "Our new monetary standard: the measurement and effects of price uncertainty, 1880-1973”, Economic Inquiry, April, pp 461-84.

Koo, R (2003): Balance sheet recessions: Japan's struggle with uncharted economics and its global implications, John Wiley and Sons.

Krugman, P (1991): “Target zones and exchange rate dynamics", Quarterly Journal of Economics, August, pp 669-82.

(1998): "It's baaack! Japan's slump and the return of the liquidity trap," Brookings Papers on Economic Activity, no 2, pp 137-205.

Kugler, P and G Rich (2002): "Monetary policy under low interest rates: the experience of Switzerland in the late 1970s", Swiss Journal of Economics and Statistics, September, pp 24169.

Kuroda, S and I Yamamoto (2003): "Are Japanese nominal wages downwardly rigid? (part II): Examinations using a friction model", Bank of Japan IMES Discussion Paper, no 2003-E4, June.

Lebow, D and J Rudd (2003): "Measurement error in the consumer price index: where do we stand?" Journal of Economic Literature, April, pp 159-201.

Lebow, D, R Saks and B Wilson (1999): "Downward wage rigidity: evidence from the employment cost index", Board of Governors of the Federal Reserve System FEDS Working Paper. Also see published version in Advances in Macroeconomics (2003).

Lebow, D, D Stockton and W Wascher (1995): "Inflation, nominal wage rigidity and the efficiency of labor markets", Board of Governors of the Federal Reserve System Finance and Economics Discussion Series, no 94-45, October.

Lucas, R (1976): "Econometric policy evaluation: a critique", Carnegie-Rochester Conference Series on Public Policy, vol 1, pp 19-46.

(2000): “Inflation and welfare", Econometrica, March, 247-74.

(2004): "Deflation and the zero lower bound", presentation at the Federal Reserve Bank of Minneapolis, November.

Masuch, K, S Nicoletti-Altimari, H Pill and M Rostagno (2002): “The role of money in monetary policy making", in O Issing (ed), Background studies for the ECB's evaluation of its monetary policy strategy, European Central Bank, pp 187-228.

McCallum, B (2000): "Theoretical analysis regarding a zero lower bound on nominal interest rates", Journal of Money, Credit and Banking, November, part 2, pp 870-904.

McCandless, G and W Weber (1995): "Some monetary facts", Federal Reserve Bank of Minneapolis Quarterly Review, Summer, pp 2-11.

McKinnon, R (1993): "The rules of the game: international money in historical perspective", Journal of Economic Literature, March, pp 1-44.

McLaughlin, K (1994): “Rigid wages?”, Journal of Monetary Economics, December, pp 383414.

(1999): “Are nominal wage changes skewed away from wage cuts?", Federal Reserve Bank of St. Louis Review, May-June, pp 117-32.

(2000): "Asymmetric wage changes and downward nominal wage rigidity", unpublished Hunter College Working Paper, October. 
Meltzer, A (1999): "Commentary: monetary policy at zero inflation", in New challenges for monetary policy, symposium sponsored by the Federal Reserve Bank of Kansas City, Jackson Hole, Wyoming, 26-28 August, pp 261-76.

(2003): A history of the Federal Reserve, volume 1, University of Chicago.

Minsky, H (1982): “Can 'it' happen again?”, Essays on instability and finance, Armonk, M E Sharpe.

Nelson, E (2003): "The future of monetary aggregates in monetary policy analysis", Journal of Monetary Economics, July, pp 1029-59.

Nurkse, R (1944): International currency experience, League of Nations.

O'Brien, A (1989): “A behavioral explanation for nominal wage rigidity during the Great Depression”, Quarterly Journal of Economics, November, pp 719-35.

Orphanides, A (2003): "Monetary policy in deflation: the liquidity trap in history and practice", unpublished Board of Governors of the Federal Reserve System working paper, December.

Orphanides, A, D Small, V Wieland and D Wilcox (1997): "A quantitative exploration of the opportunistic approach to disinflation", Board of Governors of the Federal Reserve System FEDS Working Paper, no 1997-36, June.

Orphanides, A and J Williams (2003): "Inflation scares and forecast-based monetary policy", Board of Governors of the Federal Reserve System FEDS Working Paper, no 2003-41, August.

Riksbank (2003): Inflation report, third quarter, pp 55-9.

Rodriguez-Palenzuela, D and M Wynne (2004): "Measurement bias in the HICP: what do we know, and what do we need to know?", Journal of Economic Surveys, February, pp 79-112.

Romer, C (1992): "What ended the Great Depression?", Journal of Economic History, December, pp 757-84.

Rousseau, P (2003): "Historical Perspectives on Financial Development and Economic Growth", Federal Reserve Bank of St. Louis Review, July/August, pp 81-106.

Rudebusch and Svensson (2002): "Eurosystem monetary targeting: lessons from US data", European Economic Review, March, pp 417-442.

Sargent, T (1986a): "The ends of four big inflations", in Rational expectations and inflation, Harper and Row Publishers, pp 40-109.

(1986b): "Stopping moderate inflations: the methods of Poincaré and Thatcher", in Rational expectations and inflation, Harper and Row Publishers, pp 110-57.

Schmitt-Grohé, S and M Uribe (2001): "Optimal fiscal and monetary policy under imperfect competition", CEPR Discussion Paper, no 2688, February.

Schwartz, A (1981): “Understanding 1929-33" in K Brunner (ed), The Great Depression revisited, Martinus Nijhoff, pp 5-48.

(1995): "Why financial stability depends on price stability", Economic Affairs, Autumn, pp 21-5.

Selgin, G (1997): Less than zero: the case for a falling price level in a growing economy, The Institute of Economic Affairs. 
Sellon, G (2004): "Monetary policy and the zero bound: policy options when short-term rates reach zero", Federal Reserve Bank of Kansas City Economic Review, Fourth quarter, pp 5-43.

Siklos, P (1995): Great inflations of the twentieth century, Edward Elgar Publishing.

Svensson, L (1994): "Why exchange rate bands? Monetary independence in spite of fixed rates, Journal of Monetary Economics, February, pp 157-99.

(1999a): "How should monetary policy be conducted in an era of price stability," in New challenges for monetary policy, symposium sponsored by the Federal Reserve Bank of Kansas City, Jackson Hole, Wyoming, 26-28 August, pp 195-259.

(1999b): "Price level targeting vs. inflation targeting", Journal of Money, Credit and Banking, August, pp 277-95.

(2001): "The foolproof way of escaping from a liquidity trap: is it really and can it help Japan?", Graham Lecture, Princeton University.

(2003a): "The risks of deflation and the effectiveness of monetary policy in the euro area", unpublished Princeton University working paper, August.

(2003b): "Escaping from a liquidity trap and deflation: the foolproof way and others, Journal of Economic Perspectives, Fall, pp 145-66.

Taylor, J (1999): “A historical analysis of monetary policy rules", in J Taylor (ed), Monetary policy rules, University of Chicago Press.

Temin, P (1969): The Jacksonian Economy, W W Norton and Company.

(1989): Lesson from the Great Depression, MIT Press.

Thorp, W (1926): Business annals, NBER, Inc.

Tobin, J (1975): "Keynesian models of recession and depression", American Economic Review, May, pp 195-202.

Triffin, R (1960): Gold and the dollar crisis: the future of convertibility, Yale University Press.

Triner, G (2003): "International capital flows and the banking crisis of the Brazilian encilhamento (1890-92)", unpublished Rutgers working paper.

Ueda, K (2003): "The role of capital for central banks", speech to the Japan Society of Monetary Economics, October.

Viñals, J (2001): "Monetary policy issues in a low inflation environment", Bank of Spain Working Paper, no 0107.

Von Peter, G (2004): “Debt-deflation”, unpublished Colombia University working paper, March.

Wallis, J (2001): "What caused the crisis of 1839”, NBER Historical Paper, no 133, April.

Weinstein, M (1981): "Some macroeconomic impacts of the National Industrial Recovery Act, 1933-35”, in K Brunner (ed), The Great Depression revisited, Martinus Nijhoff, pp 26281.

White, E (1990): "The stock market boom and crash of 1929 revisited", Journal of Economic Perspectives, Spring, pp 67-83.

Woodford, M (2003): Interest and prices: foundations of the theory of monetary policy, Princeton University Press. 
Yates, T (2003): "Monetary policy and the zero bound for nominal interest rates", Bank of England Quarterly Bulletin, pp 27-37.

Zarnowitz, V (1992): Business cycles: theory, history, indicators, and forecasting, University of Chicago Press.

Zurlinden, M (2003): "Gold standard, deflation and depression: the Swiss economy during the Great Depression”, Swiss National Bank Quarterly Bulletin, June, pp 86-116. 
TABLES

Table 1

Deflation frequency, annual, $1801-2002$

\begin{tabular}{|c|c|c|c|c|c|c|}
\hline & 1801-79 & 1880-1913 & 1914-49 & 1950-69 & 1970-89 & 1990-2002 \\
\hline United States & 42.4 & 23.5 & 30.6 & 5.0 & 0 & 0 \\
\hline Euro area & $\ldots$ & $\ldots$ & $\ldots$ & 0 & 0 & 0 \\
\hline Japan & $\ldots$ & 29.4 & 27.8 & 10.0 & 0 & 38.5 \\
\hline Germany & 29.1 & 29.4 & 11.1 & 10.0 & 5.0 & 0 \\
\hline France & 40.6 & 26.5 & 22.2 & 10.0 & 0 & 0 \\
\hline Italy & 33.3 & 32.4 & 25.0 & 0 & 0 & 0 \\
\hline United Kingdom & 51.9 & 44.1 & 33.3 & 0 & 0 & 0 \\
\hline Canada & 66.7 & 23.5 & 25.0 & 5.0 & 0 & 0 \\
\hline Belgium & 43.2 & 44.1 & 25.0 & 15.0 & 0 & 0 \\
\hline Switzerland & $\ldots$ & 36.4 & 36.1 & 15.0 & 0 & 0 \\
\hline Netherlands & 22.2 & 32.4 & 36.1 & 10.0 & 5.0 & 0 \\
\hline Sweden & 27.1 & 44.1 & 30.6 & 0 & 0 & 7.7 \\
\hline Denmark & 48.4 & 41.2 & 25.0 & 5.0 & 0 & 0 \\
\hline Spain & $\ldots$ & 42.4 & 27.8 & 5.0 & 0 & 0 \\
\hline Finland & 47.4 & 32.4 & 25.0 & 10.0 & 0 & 0 \\
\hline Ireland & $\ldots$ & $\ldots$ & 33.3 & 5.0 & 0 & 0 \\
\hline Norway & 45.5 & 35.3 & 36.1 & 0 & 0 & 0 \\
\hline Australia & 61.1 & 44.1 & 22.2 & 5.0 & 0 & 0 \\
\hline New Zealand & $\ldots$ & $\ldots$ & 20.0 & 0 & 0 & 7.7 \\
\hline China & $\ldots$ & $\ldots$ & $\ldots$ & $\ldots$ & 0 & 23.1 \\
\hline Hong Kong SAR & $\cdots$ & $\cdots$ & $\ldots$ & 33.3 & 0 & 30.8 \\
\hline Indonesia & 61.0 & 55.9 & 30.6 & 10.0 & 0 & 0 \\
\hline India & 33.3 & 35.3 & 36.1 & 20.0 & 5.0 & 0 \\
\hline Korea & $\ldots$ & $\ldots$ & & 5.0 & 0 & 0 \\
\hline Malaysia & $\ldots$ & $\ldots$ & 100.0 & 55.0 & 0 & 0 \\
\hline Singapore & $\ldots$ & $\ldots$ & 100.0 & 45.0 & 10.0 & 15.4 \\
\hline Thailand & $\ldots$ & $\ldots$ & & 25.0 & 5.0 & 0 \\
\hline Taiwan (China) & $\ldots$ & $\ldots$ & $\ldots$ & 16.7 & 10.0 & 15.4 \\
\hline Argentina & $\ldots$ & 41.4 & 36.1 & 5.0 & 0 & 23.1 \\
\hline Brazil & 27.8 & 44.1 & 13.9 & 0 & 0 & 0 \\
\hline Mexico & $\ldots$ & 38.5 & 25.0 & 10.0 & 0 & 0 \\
\hline Chile & 48.1 & 32.4 & 13.9 & 0 & 0 & 0 \\
\hline Venezuela & $\ldots$ & $\ldots$ & 42.9 & 15.0 & 0 & 0 \\
\hline Colombia & 6.7 & 38.2 & 36.1 & 10.0 & 0 & 0 \\
\hline Peru & $\ldots$ & $\ldots$ & 33.3 & 0 & 0 & 0 \\
\hline Egypt & $\ldots$ & $\ldots$ & 41.2 & 25.0 & 0 & 0 \\
\hline South Africa & $\cdots$ & 33.3 & 33.3 & 0 & 0 & 0 \\
\hline $\begin{array}{l}\text { Mean } \\
\text { Median }\end{array}$ & $\begin{array}{l}40.9 \\
42.8\end{array}$ & $\begin{array}{l}36.7 \\
35.9\end{array}$ & $\begin{array}{l}32.3 \\
30.6\end{array}$ & $\begin{array}{c}10.7 \\
7.5\end{array}$ & $\begin{array}{l}1.1 \\
0.0\end{array}$ & $\begin{array}{l}4.4 \\
0.0\end{array}$ \\
\hline
\end{tabular}

${ }^{1}$ Defined as percentage of negative annual changes as a proportion of all available price index data in each episode. 
Table 2

Peak to trough measure of price and corresponding output changes, by country and episode

\begin{tabular}{|c|c|c|c|c|c|c|c|c|c|c|}
\hline & \multicolumn{5}{|c|}{ CPI } & \multicolumn{5}{|c|}{ GDP } \\
\hline & $\begin{array}{l}\text { Peak } \\
\text { year }\end{array}$ & $\begin{array}{c}\text { Average } \\
\text { peak-to- } \\
\text { trough } \\
\text { decline }\end{array}$ & $\begin{array}{l}\text { Total \% } \\
\text { decline }\end{array}$ & Duration & $\begin{array}{l}\text { Year of } \\
\text { extreme } \\
\text { deflation }\end{array}$ & $\begin{array}{l}\text { Peak } \\
\text { year }\end{array}$ & $\begin{array}{c}\text { Average } \\
\text { peak-to- } \\
\text { trough } \\
\text { decline }\end{array}$ & $\begin{array}{l}\text { Total \% } \\
\text { decline }\end{array}$ & Duration & $\begin{array}{l}\text { Year of } \\
\text { extreme } \\
\text { deflation }\end{array}$ \\
\hline \multirow[t]{8}{*}{ United States } & 1837 & -5.6 & -29.2 & 6 & -15.5 & 1837 & 3.9 & 25.5 & 6 & 3.4 \\
\hline & 1847 & -4.2 & -12.1 & 3 & -12.1 & 1847 & 4.4 & 13.8 & 3 & 4.3 \\
\hline & 1857 & -4.5 & -12.9 & 3 & -8.7 & 1857 & 4.7 & 14.9 & 3 & 4.6 \\
\hline & 1866 & -3.1 & -31.4 & 12 & -6.8 & 1866 & 4.6 & 72.5 & 12 & 0.6 \\
\hline & 1881 & -2.1 & -9.9 & 5 & -3.9 & 1881 & 2.7 & 14.5 & 5 & 1.4 \\
\hline & 1891 & -0.9 & -5.3 & 6 & -2.7 & 1891 & 3.3 & 21.9 & 6 & -0.9 \\
\hline & 1920 & -8.5 & -16.3 & 2 & -10.8 & 1920 & 1.7 & 3.4 & 2 & -2.4 \\
\hline & 1926 & -4.4 & -26.9 & 7 & -10.3 & 1928 & -5.0 & -22.8 & 5 & -13.3 \\
\hline Japan & 1920 & -6.1 & -46.7 & 10 & -18.7 & 1920 & 2.3 & 25.5 & 10 & -7.3 \\
\hline \multirow[t]{8}{*}{ Germany } & 1820 & -8.0 & -34.1 & 5 & -25.0 & & & & & \\
\hline & 1831 & -5.8 & -26.0 & 5 & -15.9 & & & & & \\
\hline & 1847 & -17.4 & -43.6 & 3 & -33.8 & & & & & \\
\hline & 1855 & -2.9 & -25.6 & 10 & -18.5 & & & & & \\
\hline & 1874 & -8.2 & -15.7 & 2 & -8.4 & 1875 & -0.6 & -1.1 & 2 & -0.6 \\
\hline & 1881 & -2.1 & -11.7 & 6 & -4.0 & 1881 & 2.8 & 17.9 & 6 & 0.7 \\
\hline & 1891 & -1.3 & -6.5 & 5 & -1.4 & 1891 & 4.0 & 21.4 & 5 & -0.2 \\
\hline & 1928 & -6.2 & -22.6 & 4 & -9.6 & 1928 & -4.3 & -16.1 & 4 & -7.6 \\
\hline \multirow[t]{9}{*}{ France } & 1824 & -9.4 & -39.0 & 5 & -20.4 & 1824 & 1.9 & 10.0 & 5 & 1.8 \\
\hline & 1838 & -5.2 & -14.9 & 3 & -12.1 & 1838 & 1.3 & 4.1 & 3 & 1.3 \\
\hline & 1847 & -1.5 & -7.4 & 5 & -3.9 & 1847 & 1.1 & 5.4 & 5 & 1.0 \\
\hline & 1856 & -1.2 & -3.5 & 3 & -2.2 & 1856 & 0.9 & 2.6 & 3 & 0.8 \\
\hline & 1871 & -0.8 & -3.2 & 4 & -2.2 & 1872 & -7.0 & -7.0 & 1 & -7.0 \\
\hline & 1877 & -0.4 & -2.2 & 5 & -2.2 & 1875 & -0.5 & -2.4 & 5 & -8.2 \\
\hline & 1884 & -0.5 & -6.4 & 13 & -2.3 & 1884 & 1.4 & 19.3 & 13 & -2.1 \\
\hline & 1902 & -0.3 & -1.0 & 3 & -1.0 & 1900 & -0.4 & -1.1 & 3 & -1.6 \\
\hline & 1930 & -7.7 & -33.0 & 5 & -14.2 & 1929 & -2.1 & -11.8 & 6 & -6.5 \\
\hline \multirow[t]{3}{*}{ Italy } & 1874 & -2.1 & -19.2 & 10 & -14.4 & 1874 & 1.0 & 10.3 & 10 & -6.7 \\
\hline & 1891 & -0.7 & -5.5 & 8 & -1.9 & 1890 & -0.5 & -3.4 & 7 & -5.6 \\
\hline & 1926 & -5.6 & -36.7 & 8 & -19.1 & 1926 & 0.7 & 5.4 & 8 & -4.9 \\
\hline \multirow[t]{5}{*}{ United Kingdom } & 1847 & -6.5 & -23.5 & 4 & -12.1 & 1849 & -1.7 & -1.7 & 1 & -1.7 \\
\hline & 1860 & -4.5 & -12.9 & 3 & -11.3 & 1860 & 3.0 & 9.4 & 3 & -0.8 \\
\hline & 1873 & -3.3 & -35.2 & 13 & -9.4 & 1873 & 1.6 & 22.5 & 13 & -6.1 \\
\hline & 1891 & -4.3 & -8.4 & 2 & -8.2 & 1891 & -1.3 & -2.5 & 2 & -2.0 \\
\hline & 1920 & -5.3 & -42.3 & 10 & -27.5 & 1918 & -1.4 & -13.6 & 10 & -16.3 \\
\hline \multirow[t]{4}{*}{ Canada } & 1882 & -6.4 & -12.3 & 2 & -11.6 & 1882 & 4.1 & 8.5 & 2 & 0.4 \\
\hline & 1889 & -2.5 & -14.2 & 6 & -8.8 & 1891 & -0.6 & -1.2 & 2 & -0.6 \\
\hline & 1920 & -5.6 & -20.7 & 4 & -12.0 & 1918 & -1.7 & -6.6 & 4 & -10.8 \\
\hline & 1929 & -6.1 & -22.4 & 4 & -9.7 & 1928 & -6.8 & -29.6 & 5 & -15.4 \\
\hline \multirow[t]{9}{*}{ Belgium } & 1842 & -7.3 & -14.1 & 2 & -14.1 & & & & & \\
\hline & 1847 & -2.9 & -11.2 & 4 & -7.1 & & & & & \\
\hline & 1856 & -5.3 & -15.0 & 3 & -7.1 & & & & & \\
\hline & 1862 & -6.1 & -11.8 & 2 & -7.3 & & & & & \\
\hline & 1867 & -2.5 & -7.3 & 3 & -3.7 & & & & & \\
\hline & 1873 & -2.6 & -28.7 & 13 & -7.9 & 1873 & 1.8 & 26.8 & 13 & -0.2 \\
\hline & 1891 & -3.1 & -14.4 & 5 & -3.8 & 1891 & 2.0 & 10.2 & 5 & 0.2 \\
\hline & 1901 & -5.0 & -14.3 & 3 & -12.4 & 1901 & 2.3 & 7.0 & 3 & 0.9 \\
\hline & 1929 & -4.7 & -25.2 & 6 & -9.7 & 1928 & -1.2 & -6.7 & 6 & -4.5 \\
\hline
\end{tabular}


Table 2 (cont)

Peak to trough measure of price and corresponding output changes, by country and episode

\begin{tabular}{|c|c|c|c|c|c|c|c|c|c|c|}
\hline & \multicolumn{5}{|c|}{ CPI } & \multicolumn{5}{|c|}{ GDP } \\
\hline & $\begin{array}{l}\text { Peak } \\
\text { year }\end{array}$ & $\begin{array}{c}\text { Average } \\
\text { peak-to- } \\
\text { trough } \\
\text { decline }\end{array}$ & $\begin{array}{l}\text { Total \% } \\
\text { decline }\end{array}$ & Duration & $\begin{array}{l}\text { Year of } \\
\text { extreme } \\
\text { deflation }\end{array}$ & $\begin{array}{l}\text { Peak } \\
\text { year }\end{array}$ & $\begin{array}{c}\text { Average } \\
\text { peak-to- } \\
\text { trough } \\
\text { decline }\end{array}$ & $\begin{array}{l}\text { Total \% } \\
\text { decline }\end{array}$ & Duration & $\begin{array}{l}\text { Year of } \\
\text { extreme } \\
\text { deflation }\end{array}$ \\
\hline \multirow[t]{3}{*}{ Switzerland } & 1892 & -0.9 & -3.5 & 4 & -1.2 & 1892 & 3.9 & 16.5 & 4 & 2.5 \\
\hline & 1898 & -0.3 & -1.2 & 4 & -1.2 & 1898 & 3.3 & 13.9 & 4 & 2.9 \\
\hline & 1919 & -5.9 & -34.4 & 7 & -22.2 & 1919 & 5.0 & 40.8 & 7 & -2.5 \\
\hline \multirow[t]{2}{*}{ Netherlands } & 1892 & -5.0 & -18.6 & 4 & -10.8 & 1894 & -0.4 & -0.8 & 2 & -3.8 \\
\hline & 1920 & -3.4 & -29.3 & 10 & -14.1 & 1920 & 4.3 & 52.8 & 10 & -0.2 \\
\hline \multirow[t]{7}{*}{ Sweden } & 1842 & -5.7 & -11.0 & 2 & -6.7 & 1842 & 1.8 & 3.7 & 2 & 1.7 \\
\hline & 1847 & -1.4 & -4.2 & 3 & -2.9 & 1847 & 2.0 & 6.2 & 3 & 2.0 \\
\hline & 1857 & -8.2 & -15.7 & 2 & -10.4 & 1857 & 2.2 & 4.5 & 2 & 2.2 \\
\hline & 1862 & -3.2 & -9.2 & 3 & -5.0 & 1862 & 2.2 & 6.8 & 3 & 2.2 \\
\hline & 1874 & -2.1 & -23.7 & 13 & -6.6 & 1874 & 0.6 & 8.7 & 13 & -4.4 \\
\hline & 1891 & -3.6 & -10.4 & 3 & -5.0 & 1891 & 1.4 & 4.3 & 3 & 0.2 \\
\hline & 1920 & -4.8 & -38.7 & 10 & -19.8 & 1920 & 3.9 & 46.6 & 10 & -3.7 \\
\hline \multirow[t]{9}{*}{ Denmark } & 1831 & -5.5 & -15.7 & 3 & -7.5 & 1831 & 2.0 & 6.1 & 3 & 2.0 \\
\hline & 1836 & -2.5 & -18.6 & 8 & -12.8 & 1836 & 2.0 & 17.0 & 8 & 2.0 \\
\hline & 1847 & -5.6 & -15.9 & 3 & -11.4 & 1847 & 1.9 & 5.8 & 3 & 1.9 \\
\hline & 1856 & -4.3 & -12.2 & 3 & -8.3 & 1856 & 1.8 & 5.6 & 3 & 1.8 \\
\hline & 1867 & -3.2 & -9.3 & 3 & -6.2 & 1867 & 1.7 & 5.2 & 3 & 1.7 \\
\hline & 1874 & -1.9 & -23.1 & 14 & -7.8 & 1874 & 2.0 & 31.6 & 14 & -2.7 \\
\hline & 1891 & -3.1 & -17.4 & 6 & -5.7 & 1891 & 3.0 & 19.4 & 6 & 1.9 \\
\hline & 1902 & -1.7 & -3.4 & 2 & -3.4 & 1902 & 4.0 & 8.2 & 2 & 2.1 \\
\hline & 1920 & -3.6 & -31.0 & 10 & -12.2 & 1920 & 3.9 & 46.2 & 10 & -2.9 \\
\hline \multirow[t]{4}{*}{ Spain } & 1890 & -2.7 & -10.3 & 4 & -6.9 & 1890 & 1.5 & 6.3 & 4 & 1.5 \\
\hline & 1907 & -1.7 & -6.6 & 4 & -3.6 & 1909 & -3.0 & -3.0 & 1 & -3.0 \\
\hline & 1926 & -4.5 & -8.8 & 2 & -6.9 & 1926 & 3.8 & 7.8 & 2 & -0.4 \\
\hline & 1931 & -3.6 & -13.6 & 4 & -12.5 & 1929 & -3.6 & -25.2 & 8 & -20.0 \\
\hline \multirow[t]{3}{*}{ Finland } & 1876 & -3.1 & -29.6 & 11 & -9.8 & 1876 & 1.6 & 18.7 & 11 & -2.7 \\
\hline & 1892 & -6.1 & -17.3 & 3 & -9.9 & 1892 & 5.7 & 18.1 & 3 & -3.0 \\
\hline & 1928 & -4.6 & -21.2 & 5 & -11.2 & 1929 & -1.3 & -4.0 & 3 & -2.4 \\
\hline \multirow[t]{6}{*}{ Norway } & 1856 & -2.2 & -19.9 & 10 & -7.9 & 1856 & 2.1 & 22.9 & 10 & 2.0 \\
\hline & 1874 & -4.1 & -18.9 & 5 & -10.4 & 1876 & -1.3 & -2.7 & 2 & -3.0 \\
\hline & 1882 & -3.2 & -15.2 & 5 & -5.9 & 1882 & 0.9 & 4.6 & 5 & -0.4 \\
\hline & 1891 & -1.7 & -6.7 & 4 & -2.5 & 1891 & 1.5 & 6.3 & 4 & 0.3 \\
\hline & 1900 & -1.5 & -4.5 & 3 & -2.3 & 1900 & 1.4 & 4.4 & 3 & -0.4 \\
\hline & 1920 & -6.4 & -48.6 & 10 & -19.6 & 1920 & 3.6 & 42.3 & 10 & -8.3 \\
\hline \multirow[t]{5}{*}{ Australia } & 1873 & -1.7 & -12.6 & 8 & -4.2 & 1873 & 5.2 & 49.5 & 8 & -0.3 \\
\hline & 1882 & -2.2 & -10.7 & 5 & -3.2 & 1882 & 6.6 & 37.7 & 5 & -5.6 \\
\hline & 1890 & -6.1 & -22.2 & 4 & -8.9 & 1891 & -5.2 & -19.1 & 4 & -12.3 \\
\hline & 1902 & -3.9 & -7.6 & 2 & -5.5 & 1902 & 7.3 & 15.2 & 2 & 1.0 \\
\hline & 1929 & -5.8 & -21.2 & 4 & -9.3 & 1927 & -3.0 & -11.5 & 4 & -4.9 \\
\hline \multirow[t]{2}{*}{ New Zealand } & 1920 & -7.8 & -21.5 & 3 & -12.0 & 1920 & -5.0 & -9.8 & 2 & -6.6 \\
\hline & 1929 & -6.2 & -22.6 & 4 & -7.6 & 1929 & -5.1 & -14.6 & 3 & -8.5 \\
\hline Mean & & -4.2 & -17.8 & 5.4 & -9.4 & & 1.1 & 9.3 & 5.3 & -2.3 \\
\hline Median & & -4.0 & -15.5 & 4.0 & -8.6 & & 1.7 & 6.3 & 4.0 & -0.6 \\
\hline
\end{tabular}

Notes: Each episode was identified by smoothing the underlying price series with a 5-year moving average. Tentative peaks and troughs were identified, thereby eliminating transitory price fluctuations. Then the actual peak and trough dates were chosen using the unsmoothed series. The algorithm to identify peaks and troughs is consistent with the methodology of Bry and Boschan (1971). 
Table 3

Estimates of inflation/deflation persistence (with standard errors)

\begin{tabular}{|c|c|c|c|c|c|c|}
\hline & Pre-1880 & 1881-1913 & 1918-39 & 1945-69 & 1970-89 & 1992-2001 \\
\hline United States & $\begin{array}{c}0.201 \\
(0.129)\end{array}$ & $\begin{array}{c}0.383 \\
(0.163)\end{array}$ & $\begin{array}{c}0.573 \\
(0.155)\end{array}$ & $\begin{array}{c}0.476 \\
(0.185)\end{array}$ & $\begin{array}{c}0.703 \\
(0.169)\end{array}$ & $\begin{array}{c}0.274 \\
(0.235)\end{array}$ \\
\hline Japan & $\begin{array}{l}\ldots \\
\ldots\end{array}$ & $\begin{array}{c}0.144 \\
(0.168)\end{array}$ & $\begin{array}{c}0.666 \\
(0.156)\end{array}$ & $\begin{array}{c}0.713 \\
(0.147)\end{array}$ & $\begin{array}{c}0.665 \\
(0.18)\end{array}$ & $\begin{array}{c}0.538 \\
(0.201)\end{array}$ \\
\hline Germany & $\begin{array}{c}0.191 \\
(0.111)\end{array}$ & $\begin{array}{c}0.418 \\
(0.159)\end{array}$ & $\begin{array}{c}-0.048 \\
(0.223)\end{array}$ & $\begin{array}{c}-0.005 \\
(0.208)\end{array}$ & $\begin{array}{l}0.8 \\
(0.136)\end{array}$ & $\begin{array}{c}0.772 \\
(0.184)\end{array}$ \\
\hline France & $\begin{array}{c}0.294 \\
(0.081)\end{array}$ & $\begin{array}{c}-0.045 \\
(0.177)\end{array}$ & $\begin{array}{c}0.123 \\
(0.212)\end{array}$ & $\begin{array}{c}0.778 \\
(0.131)\end{array}$ & $\begin{array}{c}0.854 \\
(0.138)\end{array}$ & $\begin{array}{c}0.518 \\
(0.198)\end{array}$ \\
\hline United Kingdom & $\begin{array}{c}0.197 \\
(0.099)\end{array}$ & $\begin{array}{c}-0.241 \\
(0.174)\end{array}$ & $\begin{array}{c}0.029 \\
(0.224)\end{array}$ & $\begin{array}{c}0.199 \\
(0.208)\end{array}$ & $\begin{array}{c}0.677 \\
(0.169)\end{array}$ & $\begin{array}{c}0.080 \\
(0.228)\end{array}$ \\
\hline Italy & $\begin{array}{c}0.054 \\
(0.251)\end{array}$ & $\begin{array}{c}0.116 \\
(0.171)\end{array}$ & $\begin{array}{c}0.262 \\
(0.192)\end{array}$ & $\begin{array}{c}0.194 \\
(0.017)\end{array}$ & $\begin{array}{c}0.788 \\
(0.130)\end{array}$ & $\begin{array}{c}0.688 \\
(0.177)\end{array}$ \\
\hline Canada & $\begin{array}{c}0.284 \\
(0.362)\end{array}$ & $\begin{array}{c}0.088 \\
(0.179)\end{array}$ & $\begin{array}{c}0.440 \\
(0.168)\end{array}$ & $\begin{array}{c}0.408 \\
(0.189)\end{array}$ & $\begin{array}{c}0.788 \\
(0.144)\end{array}$ & $\begin{array}{c}-0.048 \\
(0.180)\end{array}$ \\
\hline Argentina & $\begin{array}{l}\cdots \\
\ldots\end{array}$ & $\begin{array}{c}0.109 \\
(0.191)\end{array}$ & $\begin{array}{c}0.052 \\
(0.21)\end{array}$ & $\begin{array}{c}0.106 \\
(0.206)\end{array}$ & $\begin{array}{c}0.997 \\
(1.079)\end{array}$ & $\begin{array}{c}0.145 \\
(0.017)\end{array}$ \\
\hline Australia & $\begin{array}{c}0.047 \\
(0.248)\end{array}$ & $\begin{array}{c}0.056 \\
(0.18)\end{array}$ & $\begin{array}{c}0.297 \\
(0.213)\end{array}$ & $\begin{array}{c}0.521 \\
(0.175)\end{array}$ & $\begin{array}{c}0.638 \\
(0.158)\end{array}$ & $\begin{array}{c}0.281 \\
(0.370)\end{array}$ \\
\hline Belgium & $\begin{array}{c}0.096 \\
(0.152)\end{array}$ & $\begin{array}{c}0.117 \\
(0.178)\end{array}$ & $\begin{array}{c}0.386 \\
(0.193)\end{array}$ & $\begin{array}{c}0.581 \\
(0.146)\end{array}$ & $\begin{array}{c}0.785 \\
(0.149)\end{array}$ & $\begin{array}{c}0.399 \\
(0.272)\end{array}$ \\
\hline Brazil & $\begin{array}{c}-0.183 \\
(0.246)\end{array}$ & $\begin{array}{c}0.403 \\
(0.164)\end{array}$ & $\begin{array}{c}0.567 \\
(0.182)\end{array}$ & $\begin{array}{c}0.764 \\
(0.132)\end{array}$ & $\begin{array}{c}0.429 \\
(0.392)\end{array}$ & $\begin{array}{c}0.590 \\
(0.295)\end{array}$ \\
\hline Chile & $\begin{array}{c}0.500 \\
(0.098)\end{array}$ & $\begin{array}{c}0.032 \\
(0.180)\end{array}$ & $\begin{array}{c}0.075 \\
(0.222)\end{array}$ & $\begin{array}{c}0.539 \\
(0.173)\end{array}$ & $\begin{array}{c}0.794 \\
(0.144)\end{array}$ & $\begin{array}{c}0.706 \\
(0.052)\end{array}$ \\
\hline Colombia & $\begin{array}{c}-0.775 \\
(0.281)\end{array}$ & $\begin{array}{c}0.647 \\
(0.137)\end{array}$ & $\begin{array}{c}0.040 \\
(0.219)\end{array}$ & $\begin{array}{c}-0.174 \\
(0.204)\end{array}$ & $\begin{array}{c}0.532 \\
(0.184)\end{array}$ & $\begin{array}{c}0.876 \\
(0.165)\end{array}$ \\
\hline Denmark & $\begin{array}{c}0.156 \\
(0.127)\end{array}$ & $\begin{array}{c}0.253 \\
(0.165)\end{array}$ & $\begin{array}{c}0.362 \\
(0.213)\end{array}$ & $\begin{array}{c}0.345 \\
(0.193)\end{array}$ & $\begin{array}{c}0.69 \\
(0.162)\end{array}$ & $\begin{array}{c}0.295 \\
(0.335)\end{array}$ \\
\hline Finland & $\begin{array}{c}0.087 \\
(0.245)\end{array}$ & $\begin{array}{c}0.456 \\
(0.145)\end{array}$ & $\begin{array}{c}0.266 \\
(0.203)\end{array}$ & $\begin{array}{c}0.063 \\
(0.208)\end{array}$ & $\begin{array}{c}0.765 \\
(0.133)\end{array}$ & $\begin{array}{c}0.460 \\
(0.219)\end{array}$ \\
\hline India & $\begin{array}{c}0.217 \\
(0.438)\end{array}$ & $\begin{array}{c}0.281 \\
(0.141)\end{array}$ & $\begin{array}{c}0.560 \\
(0.161)\end{array}$ & $\begin{array}{c}0.104 \\
(0.195)\end{array}$ & $\begin{array}{c}0.227 \\
(0.221)\end{array}$ & $\begin{array}{c}0.255 \\
(0.334)\end{array}$ \\
\hline Ireland & $\begin{array}{l}\ldots \\
\ldots\end{array}$ & $\begin{array}{l}\ldots \\
\ldots\end{array}$ & $\begin{array}{c}0.181 \\
(0.319)\end{array}$ & $\begin{array}{c}0.181 \\
(0.209)\end{array}$ & $\begin{array}{c}0.834 \\
(0.142)\end{array}$ & $\begin{array}{c}0.392 \\
(0.386)\end{array}$ \\
\hline Mexico & $\begin{array}{l}\cdots \\
\cdots\end{array}$ & $\begin{array}{c}-0.062 \\
(0.245)\end{array}$ & $\begin{array}{c}0.091 \\
(0.213)\end{array}$ & $\begin{array}{c}0.092 \\
(0.208)\end{array}$ & $\begin{array}{c}0.699 \\
(0.162)\end{array}$ & $\begin{array}{c}0.417 \\
(0.344)\end{array}$ \\
\hline Netherlands & $\begin{array}{c}0.178 \\
(0.347)\end{array}$ & $\begin{array}{c}0.064 \\
(0.18)\end{array}$ & $\begin{array}{c}0.491 \\
(0.193)\end{array}$ & $\begin{array}{c}0.251 \\
(0.198)\end{array}$ & $\begin{array}{c}0.857 \\
(0.134)\end{array}$ & $\begin{array}{c}0.586 \\
(0.474)\end{array}$ \\
\hline New Zealand & $\begin{array}{l}\cdots \\
\ldots\end{array}$ & $\begin{array}{l}\cdots \\
\ldots\end{array}$ & $\begin{array}{c}0.326 \\
(0.209)\end{array}$ & $\begin{array}{c}0.337 \\
(0.195)\end{array}$ & $\begin{array}{c}0.445 \\
(0.206)\end{array}$ & $\begin{array}{c}0.079 \\
(0.354)\end{array}$ \\
\hline Norway & $\begin{array}{c}0.21 \\
(0.152)\end{array}$ & $\begin{array}{c}0.445 \\
(0.148)\end{array}$ & $\begin{array}{c}0.273 \\
(0.157)\end{array}$ & $\begin{array}{c}0.401 \\
(0.189)\end{array}$ & $\begin{array}{c}0.210 \\
(0.216)\end{array}$ & $\begin{array}{c}0.016 \\
(0.319)\end{array}$ \\
\hline Peru & $\begin{array}{l}\cdots \\
\cdots\end{array}$ & $\begin{array}{l}\cdots \\
\cdots\end{array}$ & $\begin{array}{c}0.572 \\
(0.161)\end{array}$ & $\begin{array}{c}0.114 \\
(0.209)\end{array}$ & $\begin{array}{c}0.762 \\
(0.155)\end{array}$ & $\begin{array}{c}0.170 \\
(0.029)\end{array}$ \\
\hline Spain & $\begin{array}{l}\cdots \\
\ldots\end{array}$ & $\begin{array}{c}-0.047 \\
(0.182)\end{array}$ & $\begin{array}{c}0.523 \\
(0.197)\end{array}$ & $\begin{array}{c}0.392 \\
(0.195)\end{array}$ & $\begin{array}{c}0.805 \\
(0.114)\end{array}$ & $\begin{array}{c}0.730 \\
(0.175)\end{array}$ \\
\hline Sweden & $\begin{array}{c}0.416 \\
(0.122)\end{array}$ & $\begin{array}{c}0.389 \\
(0.159)\end{array}$ & $\begin{array}{c}0.688 \\
(0.136)\end{array}$ & $\begin{array}{c}0.197 \\
(0.202)\end{array}$ & $\begin{array}{c}0.522 \\
(0.174)\end{array}$ & $\begin{array}{c}0.188 \\
(0.167)\end{array}$ \\
\hline Venezuela & $\begin{array}{l}\cdots \\
\ldots\end{array}$ & $\begin{array}{l}\cdots \\
\ldots \\
\end{array}$ & $\begin{array}{l}0.28 \\
0.218 \\
\end{array}$ & $\begin{array}{l}0.111 \\
0.178 \\
\end{array}$ & $\begin{array}{l}0.735 \\
0.281 \\
\end{array}$ & $\begin{array}{l}0.605 \\
0.317 \\
\end{array}$ \\
\hline Mean & .13 & .19 & .32 & .31 & .68 & .40 \\
\hline Median & .19 & .12 & .30 & .25 & .74 & .40 \\
\hline
\end{tabular}


Table 4

Asymmetric persistence tests for price changes in the pre-1913 period

\begin{tabular}{|c|c|c|c|c|c|}
\hline Countries & Period & $\begin{array}{c}\text { Percent of } \\
\text { observations } \\
I_{t}=1\end{array}$ & $1+\rho_{1}$ & $1+\rho_{2}$ & F-stat \\
\hline Argentina & $1886-1913$ & 43 & -0.41 & 0.78 & $17.03 * * *$ \\
\hline Australia & $1880-1913$ & 44 & 0.05 & 0.07 & 0.01 \\
\hline Belgium & $1880-1913$ & 44 & 0.18 & 0.12 & 0.02 \\
\hline Brazil & $1880-1913$ & 44 & -0.14 & 0.52 & 2.53 \\
\hline Canada & $1880-1913$ & 24 & 0.00 & 0.12 & 0.11 \\
\hline Switzerland & $1882-1913$ & 38 & 0.87 & 0.25 & $4.48^{*}$ \\
\hline Chile & $1880-1913$ & 32 & -0.25 & 0.58 & $7.26^{*}$ \\
\hline China & $\ldots$ & $\ldots$ & $\ldots$ & $\ldots$ & $\ldots$ \\
\hline Germany & $1880-1913$ & 29 & 0.09 & 0.49 & 1.17 \\
\hline Denmark & $1880-1913$ & 41 & 0.19 & 0.09 & 0.07 \\
\hline Spain & $1882-1913$ & 44 & -0.16 & 0.02 & 0.22 \\
\hline Finland & $1880-1913$ & 32 & 0.37 & 0.30 & 0.02 \\
\hline France & $1880-1913$ & 27 & -0.76 & 0.03 & 2.02 \\
\hline Hong Kong & $\ldots$ & $\ldots$ & $\ldots$ & $\ldots$ & $\ldots$ \\
\hline Indonesia & $1880-1913$ & 56 & -0.38 & -0.92 & 2.50 \\
\hline Ireland & $\ldots$ & $\ldots$ & $\ldots$ & $\ldots$ & $\ldots$ \\
\hline India & $1880-1913$ & 35 & 0.27 & 0.00 & 0.53 \\
\hline Italy & $1880-1913$ & 32 & 0.09 & 0.05 & 0.01 \\
\hline Japan & $1880-1913$ & 30 & -0.21 & 0.40 & $4.17^{*}$ \\
\hline Korea & $\ldots$ & $\ldots$ & $\ldots$ & $\ldots$ & $\ldots$ \\
\hline Mexico & $1902-1913$ & 42 & -0.30 & 0.12 & 0.94 \\
\hline Malaysia & $\ldots$ & $\ldots$ & $\ldots$ & $\ldots$ & $\ldots$ \\
\hline Netherlands & $1880-1913$ & 32 & 0.04 & 0.07 & 0.01 \\
\hline Norway & $1880-1913$ & 35 & 0.54 & 0.11 & 1.40 \\
\hline New Zealand & $\ldots$ & $\ldots$ & $\ldots$ & $\ldots$ & $\ldots$ \\
\hline Sweden & $1880-1913$ & 44 & 0.69 & 0.08 & 2.89 \\
\hline Singapore & $\ldots$ & $\ldots$ & $\ldots$ & $\ldots$ & $\ldots$ \\
\hline Thailand & $\ldots$ & $\ldots$ & $\ldots$ & $\ldots$ & $\ldots$ \\
\hline Taiwan & $\ldots$ & $\ldots$ & $\ldots$ & $\ldots$ & $\ldots$ \\
\hline United States & $1880-1913$ & 24 & 0.24 & 0.47 & 0.43 \\
\hline United Kingdom & $1880-1913$ & 44 & 0.08 & -0.54 & $3.31^{*}$ \\
\hline Mean & & & 0.05 & 0.15 & \\
\hline Median & & & 0.07 & 0.12 & \\
\hline
\end{tabular}

Note: Inflation tests of the threshold autoregressive (TAR) model during the gold standard period is specified as the following: $\pi_{t}-\pi_{t-1}=\beta+I_{t} \rho_{1} \pi_{t-1}+\left(1-I_{t}\right) \rho_{2} \pi_{t-1}+\varepsilon_{t}$ where $I_{t}$ is a heaviside indicator function such that $I_{t}=\left\{\begin{array}{l}0, \text { if } \pi_{t-1} \geq 0 \\ 1, \text { if } \pi_{t-1}<0\end{array}\right.$. The significance level of the test of the null of symmetry, $H_{0}: \rho_{1}=\rho_{2}$, is reported in the final column using monte carlo generated critical values: $*=90 \%, * *=95 \%$ and $* * *=99 \%$. This tests whether inflation persistence was similar during deflationary and inflationary periods during the heyday of the gold standard period. Assuming that inflation was stationary, the appropriate measure of persistence is $1+\rho_{i}$. Enders and Granger (1998) focus on unit root tests in the presence of asymmetric persistence. Consistent with their approach, we account for the possibility of non-standard probability distributions of the test statistics by using Monte Carlo methods even when there is little evidence of unit roots. 
Table 5

Asymmetric persistence tests for de-trended inflation changes during the great inflation period

\begin{tabular}{|c|c|c|c|c|c|}
\hline Countries & Period & $\begin{array}{c}\text { Percent of } \\
\text { observations } \\
\mathbf{I}_{\mathbf{t}}=\mathbf{1}\end{array}$ & $1+\rho_{1}$ & $1+\rho_{2}$ & F-stat \\
\hline Argentina & $1960-2003$ & 61 & 0.14 & 0.50 & 1.43 \\
\hline Australia & $1960-2003$ & 50 & 0.34 & 0.55 & 0.42 \\
\hline Belgium & $1960-2003$ & 52 & 0.66 & 0.58 & 0.07 \\
\hline Brazil & $1960-2003$ & 55 & -0.08 & 1.61 & $20.61 * * *$ \\
\hline Canada & $1960-2003$ & 57 & 0.27 & 0.79 & $3.50 * *$ \\
\hline Switzerland & $1960-2003$ & 52 & 0.45 & 0.68 & 0.67 \\
\hline Chile & $1960-2003$ & 59 & 0.95 & 0.61 & 1.14 \\
\hline China & $1977-2003$ & 63 & 0.46 & 0.46 & 0.00 \\
\hline Germany & $1960-2003$ & 41 & 0.50 & 0.83 & $14.71 * * *$ \\
\hline Denmark & $1960-2003$ & 50 & 0.18 & 0.24 & 0.04 \\
\hline Spain & $1960-2003$ & 52 & 0.47 & 0.60 & 0.20 \\
\hline Finland & $1960-2003$ & 55 & 0.34 & 0.53 & 0.40 \\
\hline France & $1960-2003$ & 52 & 0.50 & 0.50 & 0.00 \\
\hline Hong Kong & $1960-2003$ & 50 & 0.10 & 0.46 & 1.43 \\
\hline Indonesia & $1960-2003$ & 64 & -0.04 & 0.18 & 0.04 \\
\hline Ireland & $1960-2003$ & 57 & 0.38 & 0.54 & 0.34 \\
\hline India & $1960-2003$ & 59 & 0.07 & 0.41 & 1.19 \\
\hline Italy & $1960-2003$ & 43 & 0.55 & 0.69 & 0.21 \\
\hline Japan & $1960-2003$ & 55 & 1.09 & 0.33 & 2.19 \\
\hline Korea & $1960-2003$ & 50 & 0.51 & 0.44 & 0.06 \\
\hline Mexico & $1960-2003$ & 52 & 0.21 & 0.61 & 1.93 \\
\hline Malaysia & $1960-2003$ & 55 & 0.09 & 0.88 & $5.50 * * *$ \\
\hline Netherlands & $1960-2003$ & 52 & 0.36 & 0.43 & 0.06 \\
\hline Norway & $1960-2003$ & 55 & 0.33 & -0.01 & 1.20 \\
\hline New Zealand & $1960-2003$ & 57 & 0.15 & 0.22 & 0.04 \\
\hline Sweden & $1960-2003$ & 52 & 0.20 & 0.22 & 0.00 \\
\hline Singapore & $1960-2003$ & 55 & 0.11 & 0.80 & $5.54 * *$ \\
\hline Thailand & $1960-2003$ & 57 & 0.08 & 0.59 & 2.87 \\
\hline Taiwan & $1960-2003$ & 59 & 0.01 & 0.47 & 1.38 \\
\hline United States & $1960-2003$ & 59 & 0.34 & 0.63 & 1.01 \\
\hline United Kingdom & $1960-2003$ & 55 & 0.48 & 0.34 & 0.15 \\
\hline Mean & & & .33 & .54 & \\
\hline Median & & & .34 & .53 & \\
\hline
\end{tabular}

Note: Inflation tests of the threshold autoregressive (TAR) model during the great inflation period is specified as the following: $\quad \tilde{\pi}_{t}-\tilde{\pi}_{t-1}=\beta+I_{t} \rho_{1} \tilde{\pi}_{t-1}+\left(1-I_{t}\right) \rho_{2} \tilde{\pi}_{t-1}+\varepsilon_{t}$ where $I_{t}$ is a heaviside indicator function such that $I_{t}=\left\{\begin{array}{l}0, \text { if } \tilde{\pi}_{t-1} \geq 0 \\ 1, \text { if } \tilde{\pi}_{t-1}<0\end{array}\right.$ and $\tilde{\pi}$ is the deviation of inflation from its Hodrick-Prescott trend $(\lambda=100)$. The significance level of the test of the null of symmetry, $H_{0}: \rho_{1}=\rho_{2}$ is also reported in the final column. The significance level of the test of the null of symmetry, $H_{0}: \rho_{1}=\rho_{2}$, is reported in the final column using monte carlo generated critical values: $*=90 \%, * *=95 \%$ and $* * *=99 \%$. This tests whether the persistence of deviations of inflation from its trend was similar during disinflationary and reflationary periods during the great inflation period. 
Table 6

Panel symmetry tests for inflation, 1880-1913

\begin{tabular}{|c|c|c|c|c|c|c|c|c|c|}
\hline \multirow{3}{*}{$\pi_{t-1}<0$} & \multicolumn{4}{|c|}{$\begin{array}{l}\text { United States and } \\
\text { the United Kingdom }\end{array}$} & \multicolumn{5}{|c|}{ G10 countries } \\
\hline & (1) & (2) & (3) & (4) & (5) & (6) & (7) & (8) & (9) \\
\hline & $\begin{array}{l}.05 \\
(.20)\end{array}$ & $\begin{array}{l}-.01 \\
(.20)\end{array}$ & $\begin{array}{l}-.02 \\
(.20)\end{array}$ & $\begin{array}{l}.22 \\
(.36)\end{array}$ & $\begin{array}{c}.23 \\
(.003)^{* *}\end{array}$ & $\begin{array}{c}.34 \\
(.10)^{* * *}\end{array}$ & $\begin{array}{l}.17 \\
(.10)^{*}\end{array}$ & $\begin{array}{l}.18 \\
(.12)\end{array}$ & $\begin{array}{l}.01 \\
(.14)\end{array}$ \\
\hline$\pi_{t-1} \geq 0$ & $\begin{array}{l}-.01 \\
(.23)\end{array}$ & $\begin{array}{l}-.13 \\
(.23)\end{array}$ & $\begin{array}{l}-.12 \\
(.23)\end{array}$ & $\begin{array}{l}-.10 \\
(.37)\end{array}$ & $\begin{array}{c}.19 \\
(.08)^{* *}\end{array}$ & $\begin{array}{c}0.28 \\
(.09)^{* * *}\end{array}$ & $\begin{array}{l}.16 \\
(.09)^{*}\end{array}$ & $\begin{array}{l}.19 \\
(.11)^{*}\end{array}$ & $\begin{array}{c}.09 \\
(.13)\end{array}$ \\
\hline $\begin{array}{l}\text { Money } \\
\text { growth }_{t-1}\end{array}$ & & $\begin{array}{l}.18 \\
(.09)^{*}\end{array}$ & $\begin{array}{c}.22 \\
(.10)^{* *}\end{array}$ & $\begin{array}{l}.08 \\
(.12)\end{array}$ & & $\begin{array}{c}.15 \\
(.03)^{* * *}\end{array}$ & $\begin{array}{c}.14 \\
(.03)^{* * *}\end{array}$ & $\begin{array}{c}.14 \\
(.03)^{* * *}\end{array}$ & $\begin{array}{l}.12 \\
(.06)^{*}\end{array}$ \\
\hline $\begin{array}{l}\text { Output } \\
\text { gap }_{t-1}\end{array}$ & & & $\begin{array}{l}-.002 \\
(.002)\end{array}$ & & & & $\begin{array}{c}-.001 \\
(.0007)\end{array}$ & & \\
\hline $\begin{array}{l}\text { Supply } \\
\text { shocks } t_{t-1}\end{array}$ & & & & $\begin{array}{l}-.06 \\
(.10)\end{array}$ & & & & $\begin{array}{l}-.02 \\
(.03)\end{array}$ & \\
\hline $\begin{array}{l}\text { Demand } \\
\text { shocks }_{t-1}\end{array}$ & & & & $\begin{array}{l}.01 \\
(.05)\end{array}$ & & & & $\begin{array}{l}-.00 \\
(.02)\end{array}$ & \\
\hline $\begin{array}{l}\text { Bank } \\
\text { Crises }_{t-1}\end{array}$ & & & & & & & & & $\begin{array}{l}.01 \\
(.01)\end{array}$ \\
\hline $\begin{array}{l}\text { Equity } \\
\text { prices }_{t-1}\end{array}$ & & & & $\begin{array}{l}.08 \\
(.05)\end{array}$ & & & & & $\begin{array}{c}.05 \\
(.02)^{* *}\end{array}$ \\
\hline $\bar{R}^{2}$ & -.03 & .01 & .02 & .01 & .04 & .11 & .11 & .09 & .08 \\
\hline $\begin{array}{l}\text { Symmetry } \\
\text { test }\end{array}$ & .85 & .74 & .78 & .39 & .71 & .71 & .92 & .95 & .69 \\
\hline $\begin{array}{l}\text { Number of } \\
\text { obs. }\end{array}$ & 68 & 68 & 68 & 66 & 371 & 324 & 324 & 319 & 163 \\
\hline
\end{tabular}

The statistical model is $\pi_{i, t}=\rho_{1} I_{i, t} \pi_{t-1}+\rho_{2}\left(1-I_{i, t}\right) \pi_{t-1}+\beta X_{t-1}+\varepsilon_{i, t}$, where the model is estimated as a pooled regression (unbalanced panel). If the country constants were statistically different at the $95 \%$ confidence level, the model was estimated with fixed effects instead of a common constant. The regressors include the first lag of the country-specific annual growth rate of money, output gap, supply shocks, demand shocks, banking crisis variable and annual growth rate of real equity prices. The banking crisis indicator and money growth is from Bordo et al (2001). The supply and demand shocks were constructed estimated using a Blanchard and Quah (1989) long-run restrictions model for real GDP growth and inflation. The sources for the variables are described in Borio and Filardo (2004). The standard errors are in parentheses and the asterisks indicate the $10 \%, 5 \%$ and $1 \%$ significance levels, respectively. The G10 countries include Belgium, Canada, Germany, France, Italy, Japan, the Netherlands, Sweden, Switzerland, the United Kingdom and the United States. 
Table 7

Statistical determinants of the good, the bad and the ugly deflation, full sample

\begin{tabular}{|c|c|c|c|c|c|c|c|c|c|}
\hline & (1) & (2) & (3) & (4) & (5) & (6) & (7) & (8) & (9) \\
\hline$(\mathrm{P}-\mathrm{P} *) / \mathrm{P}^{*}$ & & $\begin{array}{c}.07 \\
(.08)\end{array}$ & $\begin{array}{c}.48 \\
(.25)^{* *}\end{array}$ & $\begin{array}{c}0.48 \\
(.27)^{*}\end{array}$ & $\begin{array}{c}.48 \\
(.28)^{*}\end{array}$ & $\begin{array}{c}.48 \\
(.29)^{*}\end{array}$ & $\begin{array}{c}.78 \\
(.36)^{* *}\end{array}$ & $\begin{array}{c}.47 \\
(.25)^{*}\end{array}$ & $\begin{array}{c}1.69 \\
(.88)^{*}\end{array}$ \\
\hline $\begin{array}{l}\text { Banking } \\
\text { crises }\end{array}$ & & & $\begin{array}{c}1.80 \\
(.70)^{* *}\end{array}$ & $\begin{array}{c}1.79 \\
(.72)^{* *}\end{array}$ & $\begin{array}{l}.1 .41 \\
(.79)^{*}\end{array}$ & $\begin{array}{l}1.41 \\
(.80)\end{array}$ & $\begin{array}{c}2.68 \\
(.95)^{* * *}\end{array}$ & $\begin{array}{c}1.77 \\
(.71)^{* *}\end{array}$ & $\begin{array}{c}5.61 \\
(2.59)^{* *}\end{array}$ \\
\hline $\begin{array}{l}\text { Money } \\
\text { growth }\end{array}$ & $\begin{array}{c}.04 \\
(.02)^{* *}\end{array}$ & & & $\begin{array}{c}-.004 \\
(0.04)\end{array}$ & & & & & \\
\hline $\begin{array}{l}\text { Supply } \\
\text { shocks }\end{array}$ & & & & & $\begin{array}{l}-.32 \\
(.30)\end{array}$ & $\begin{array}{l}-.31 \\
(.34)\end{array}$ & & & \\
\hline $\begin{array}{l}\text { Demand } \\
\text { shocks }\end{array}$ & & & & & & $\begin{array}{c}.05 \\
(.11)\end{array}$ & & & \\
\hline $\begin{array}{l}\text { Wage } \\
\text { inflation }\end{array}$ & & & & & & & $\begin{array}{c}.02 \\
(.10)\end{array}$ & & \\
\hline $\begin{array}{l}\text { Interest } \\
\text { rates }\end{array}$ & & & & & & & & $\begin{array}{l}.13 \\
(.30)\end{array}$ & \\
\hline $\begin{array}{l}\text { Equity } \\
\text { prices }\end{array}$ & & & & & & & & & $\begin{array}{l}-.04 \\
(.07)\end{array}$ \\
\hline $\mathrm{R}^{2}$ & .05 & .02 & .24 & .24 & .28 & .29 & .44 & .25 & .72 \\
\hline $\begin{array}{l}\text { Number of } \\
\text { obs. }\end{array}$ & 57 & 45 & 32 & 32 & 32 & 32 & 23 & 32 & 22 \\
\hline
\end{tabular}

\begin{tabular}{c|ccccccccc}
\hline \hline Fit - actual/estimated & \multicolumn{10}{l}{} & $=$ \\
\hline Good & $39 / 54$ & $36 / 45$ & $26 / 30$ & $25 / 29$ & $26 / 31$ & $26 / 31$ & $18 / 18$ & $26 / 31$ & $18 / 18$ \\
Bad & $10 / 0$ & $5 / 0$ & $4 / 1$ & $4 / 0$ & $4 / 0$ & $4 / 0$ & $4 / 5$ & $4 / 0$ & $3 / 3$ \\
Ugly & $8 / 3$ & $4 / 0$ & $2 / 1$ & $2 / 2$ & $2 / 1$ & $2 / 1$ & $0 / 1$ & $2 / 1$ & $1 / 1$ \\
\hline \hline
\end{tabular}

Marginal effect of the crisis indicator on the probability of the good, the bad and the ugly (Model 4)

No banking crisis $\left(\mathrm{C}_{\mathrm{i}}=0\right)$

$\mathrm{P}($ good $)$ $\mathrm{P}(\mathrm{bad})$

P(ugly)

Banking crisis $\left(\mathrm{C}_{\mathrm{i}}=1\right)$

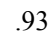

.38

.06

.01

Difference

.55

.34

.28

$-.28$

$-.27$

Notes: The regressors are five-year averages prior to the peak in the price level for each episode. Construction of the supply and demand shocks and $\mathrm{P}^{*}$ variable are described in the Technical Appendix. The other variables are described in Table 6. Real wage inflation, long-term interest rates and real equity prices variables are described in Borio and Filardo (2004). The $\mathrm{R}^{2}$ is measured by the likelihood ratio index. The in-sample fit statistics provide an indication of how well the model fits the data by comparing the actual number of observations of the good, the bad and the ugly deflations in the sample with those implied by the model. The marginal effects are evaluated at the means of the dependent variables in the model, except of course for $\mathrm{C}_{\mathrm{i}}$. 


\section{GRAPHS}

Graph 1

Supply and demand shocks during the 1921-1929 period

\section{Percent}

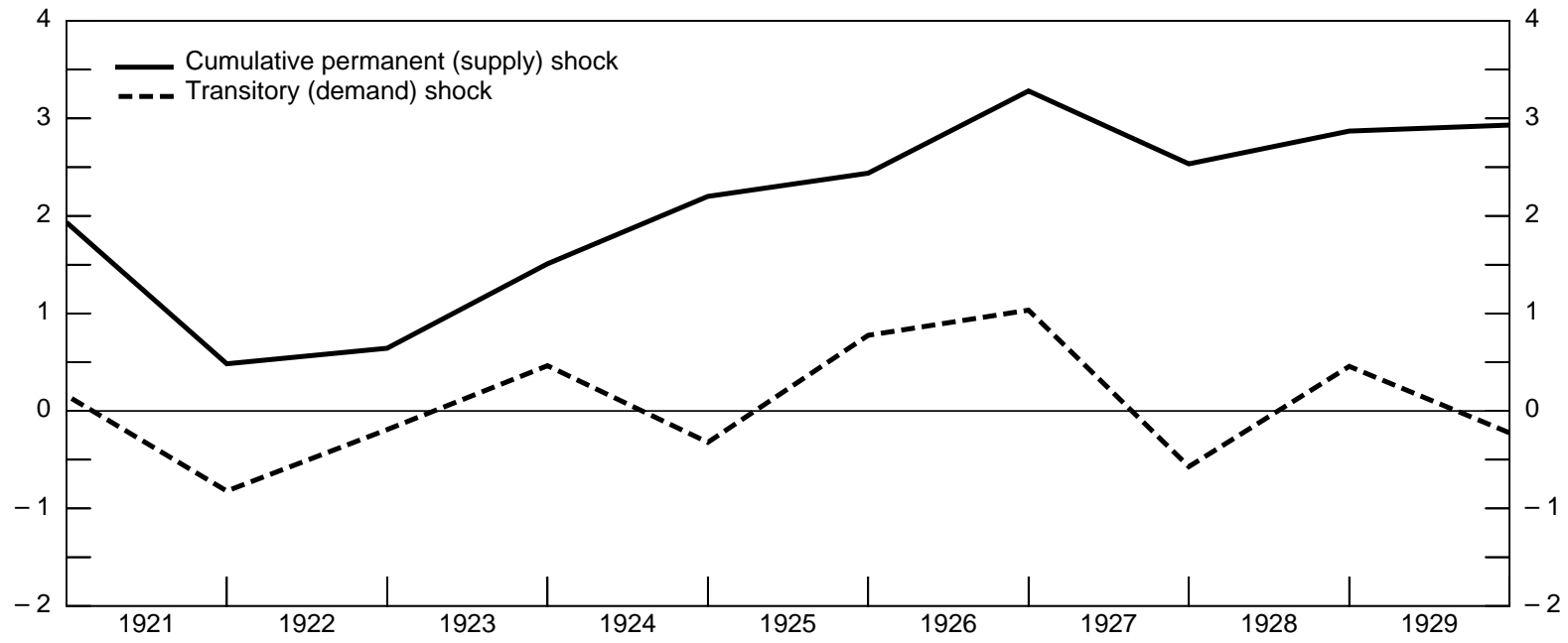

Notes: The supply and demand shocks were estimated using a Blanchard-Quah (1989) shock identification method. A model of inflation and output was first estimated from 1880-1938 and the historical shocks were decomposed into those associated with the permanent, or supply, component and those associated with the transitory, or demand, component. See appendix for more details on the statistical method. 
Graph 2

Deflation episodes and output performance

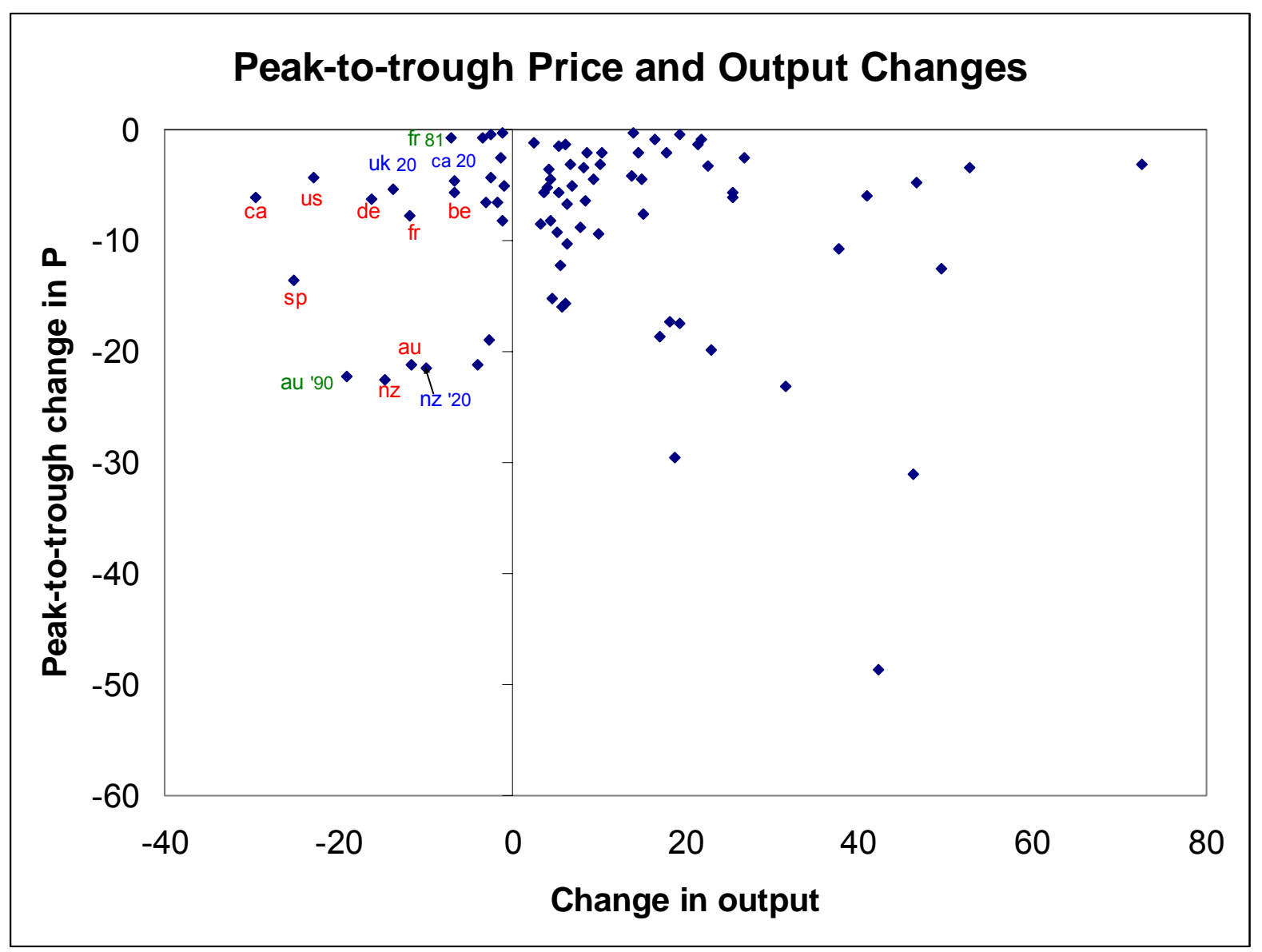

Notes: The data are from Table 2. The non-dated, labelled data points are from those in the Great Contraction era: au= Australia, be $=$ Belgium, $\mathrm{ca}=$ Canada, de $=$ Germany, $\mathrm{fr}=$ France, $\mathrm{sp}=$ Spain, $\mathrm{nz}=$ New Zealand, $\mathrm{uk}=$ United Kingdom, $\mathrm{us}=$ United States. The following dated labels denote deflations with peaks before the Great Contraction: fr ' $81=$ France (peak 1881), au ' 90 = Australia (peak 1890), ca '20 = Canada (peak 1920), nz '20 = New Zealand (peak 1920), uk '20= United Kingdom (peak 1920). 
Graph 3

Interest rates and deflation

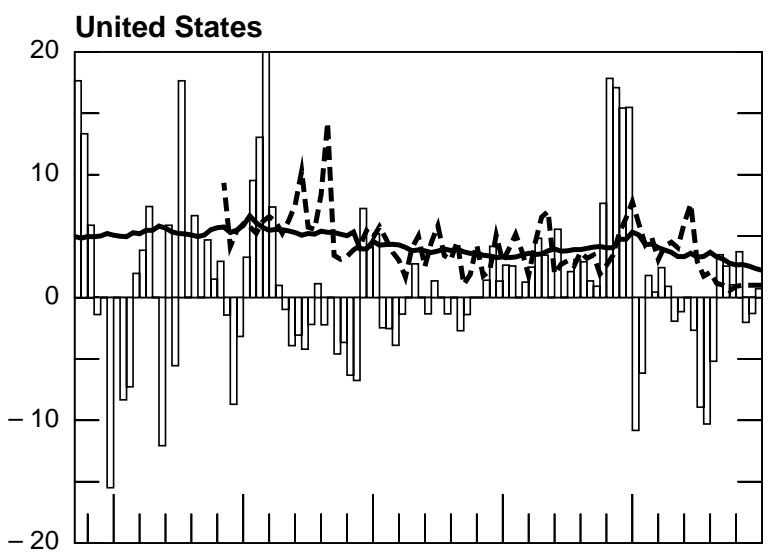

United Kingdom
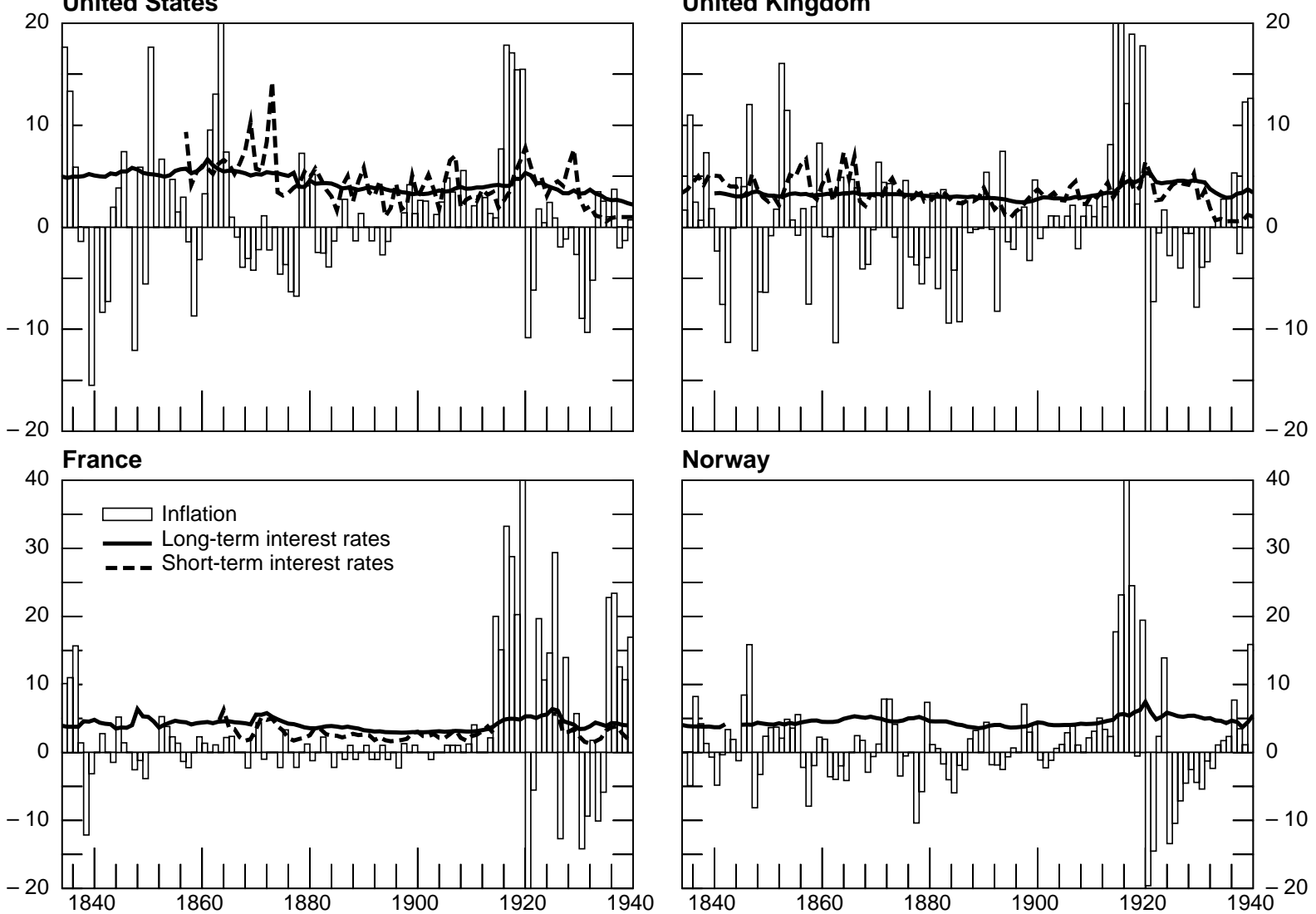

Notes: The inflation bars represent annual consumer price inflation. The short-term rates: U.S. call money rates; Great Britian 3-month Sterling interbank deposit rate (from 1864), minimum rate of discount (from 1936); France discount rate. The longterm rates: US yield on long-term Treasury bonds; GB yield on consul bonds; France yield on long-term government notes; Norway long-term government bond yields. 
Graph 4

Monetary policy and deflation: the zonal view

\section{Relative policy value}

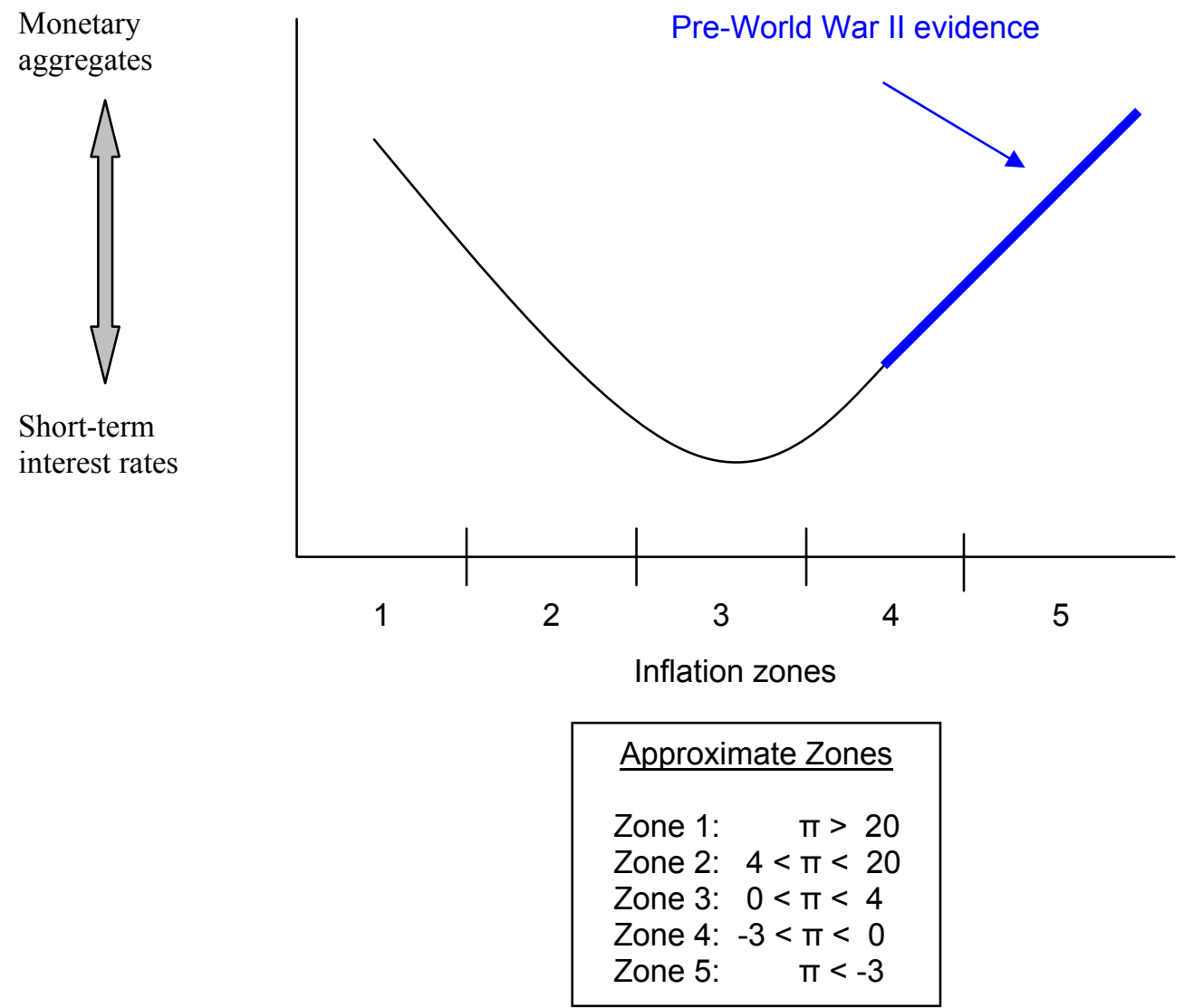

